- RECEIVED by tic AUg 81977

\title{
LOFT FUEL MODULES DESIGN, CHARACTERIZATION, AND FABRICATION PROGRAM
}

\author{
MALCOLM L. RUSSELL
}

June 1977

EG\&G Idaho, Inc. 


\section{DISCLAIMER}

This report was prepared as an account of work sponsored by an agency of the United States Government. Neither the United States Government nor any agency Thereof, nor any of their employees, makes any warranty, express or implied, or assumes any legal liability or responsibility for the accuracy, completeness, or usefulness of any information, apparatus, product, or process disclosed, or represents that its use would not infringe privately owned rights. Reference herein to any specific commercial product, process, or service by trade name, trademark, manufacturer, or otherwise does not necessarily constitute or imply its endorsement, recommendation, or favoring by the United States Government or any agency thereof. The views and opinions of authors expressed herein do not necessarily state or reflect those of the United States Government or any agency thereof. 


\section{DISCLAIMER}

Portions of this document may be illegible in electronic image products. Images are produced from the best available original document. 
Printed in the United States of America

Available from

National Technical Information Service

U.S. Department of Commerce

5285 Port Royal Road

Springfield, Virginia 22161

Price: Printed Copy $\$ 5.50$; Microfiche $\$ 3.00$

"The NRC will make available data tapes and operational computer codes on research programs dealing with postulated loss-of-coolant accidents in light water reactors. Persons requesting this information must reimburse the NRC contractors for their expenses in preparing copies of the data tapes and the operational computer codes. Requests should be submitted to the Research Applications Branch, Office of Nuclear Regulatory Research, Nuclear Regulatory Commission, Washington, D.C. 20555."

\section{NOTICE}

This report was prepared as an account of work sponsored by the United States Government. Neither the United States nor the Energy Research and Development Administration, nor the Nuclear Regulatory Commission, nor any of their employees, nor any of their contractors, subcontractors, or their employees, makes any warranty, express or implied, or assumes any legal liability or responsibility for the accuracy, completeness or usefulness of any information, apparatus, product or process disclosed, or represents that its use would not infringe privately owned rights. 
.TREE-NUREG-1 131

LOFT FUEL MODULES DESIGN,

CHARACTERIZATION, AND FABRICATION PROGRAM

Approved:

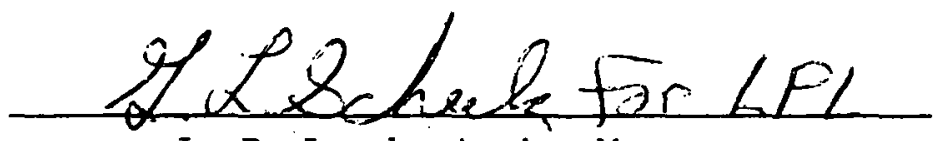

L. P. Leach, Acting Manager

LOFT Experimental Program Division
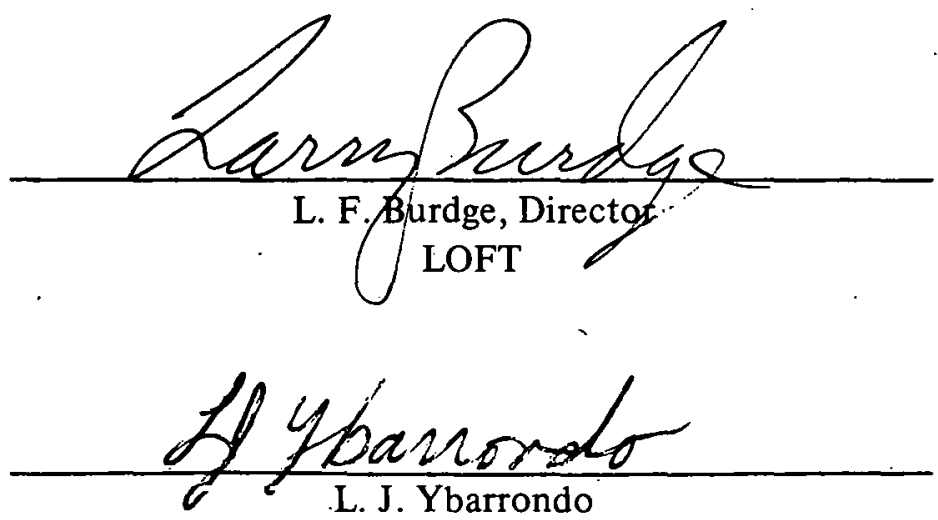

Director, Water Reactor Research

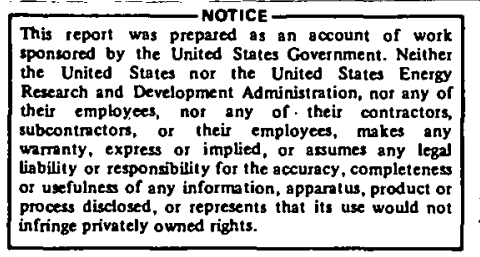

infinge privately ouned rights. 


\title{
LOFT FUEL MODULES DESIGN,
}

\section{CHARACTERIZATION, AND FABRICATION PROGRAM}

\author{
by \\ Malcolm L. Russell
}

EG\&G IDAHO, INC.

June 1977

-PREPARED FOR THE

U. S. ENERGY RESEARCH AND DEVELOPMENT ADMINISTRATION

IDAHO OPERATIONS.OFFICE

UNDER CONTRACT NO. EY-76-C-07-1570 


\section{ACKNOWI.FDGMENTS.}

H.A. Rau managed the design, development, and fabrication program for the instrumentation penetration assemblies and the rabrication program for the fuel modulc assembly. C. E. Forkel managed the fabrication program for the upper support structures. D. W. Hood, R. D. Wesley, and R. K. Welty (Exxon) provided technical supervision of the fuel rod thermocouple attachment (laser welding) program. 


\begin{abstract}
The loss-of-fluid test (LOFT) fuel modules have evolved from a comprehensive five-year design, characterization, and fabrication program which has resulted in the accomplishment of many technical activities of interest in pressurized water reactor fuel design development and safety research. This report summarizes the highlights which include:

(1) Determination of fundamental high-temperature reactor material properties

(2) Design invention related to in-core instrumentation attachment

(3) Implementation of advanced and/or unique fuel bundle characterization techniques

(4) Implementation of improved fuel bundle fabrication techniques

(5) Planning and execution of a multimillion dollar design, characterization, and fabrication program for pressurized water reactor fuel.

The total program described herein has achieved an objective of technical activity documentation and component characterization in a manner that (a) indicates the effort to provide a fuel module that will credibly represent a large pressurized water reactor (LPWR) fuel bundle during a loss-of-coolant accident (LOCA) and (b) determines the representative characteristics of the LOFT fuel bundles.
\end{abstract}

This document is an updated version of the previously published Aerojet Nuclear Company Report ANCR-1223, LOFT Fuel Modules Design Characterization and Fabrication Program, October 1975, which was distributed under categnry NRC-3. 


\section{CONTENTS}

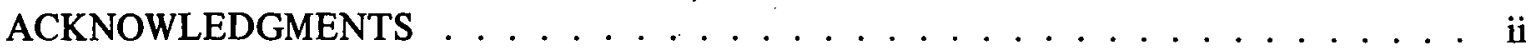

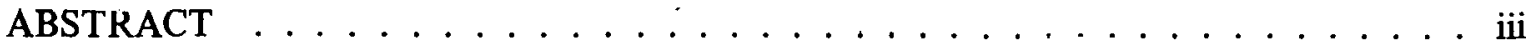

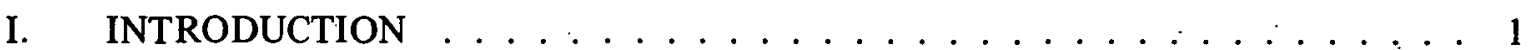

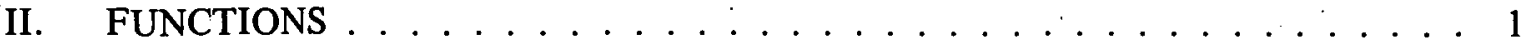

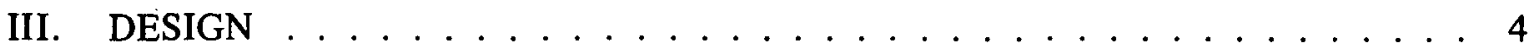

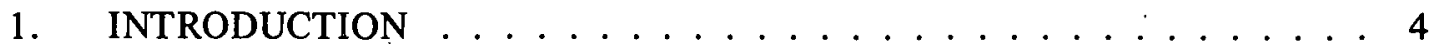

2. MECHANICAL DESIGN ................. 4

2.1 Fuel Modules ...................... . 4

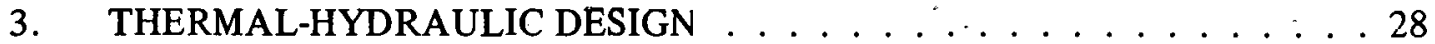

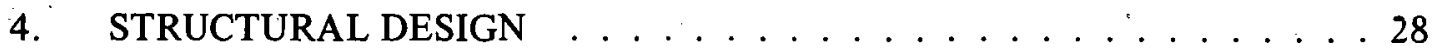

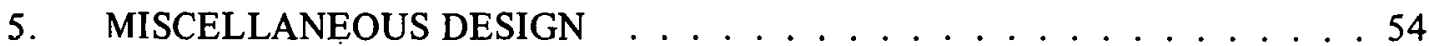

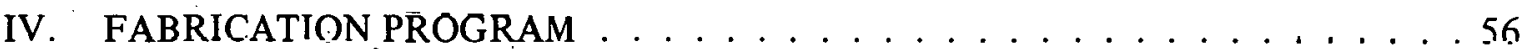

1. PREPRODUCTION PROCESS DEMONST̄T̄TATION

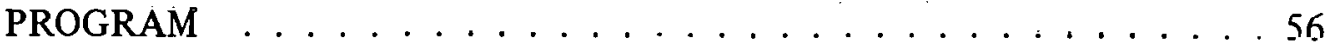

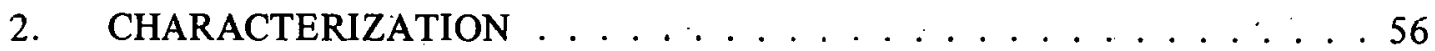

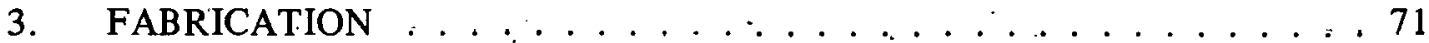

31 I aser Welding . . . . . . . . . . . . . . . 71

3.2 Fuel Bundle Assembly . . . . . . . . . . . . . . . . . 73

3.3 Fuel Module Assemhly . . . . . . . . . . . . . . . 73

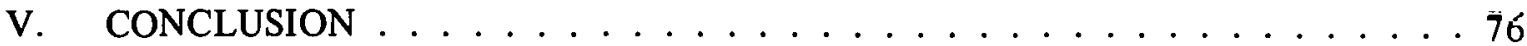

APPENDIX A - LOFT FUEL MOUULE ASSEMBLY DRAWINGS . . . . . . . . . 77 


\section{FIGURES}

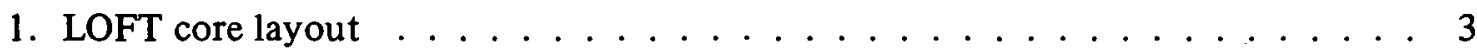

2. LOFT instrumented pressurized end cap . . . . . . . . . . . . . . 10

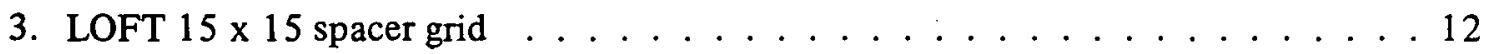

4. LOFT control rod spider . . . . . . . . . . . . . . . . 13

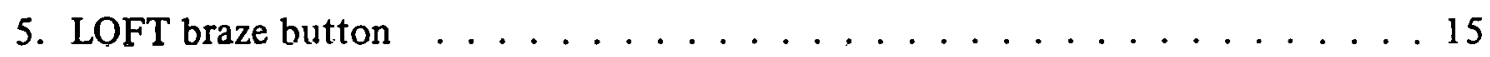

6. LOFT instrumented fuel rod . . . . . . . . . . . . . 17

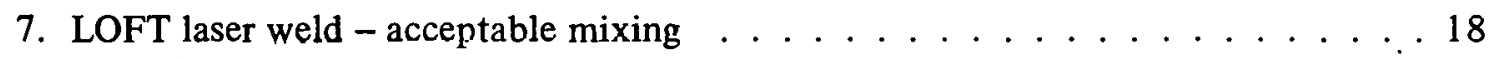

8. LOFT laser weld - too much mixing . . . . . . . . . . . . 18

9. LOFT laser weld - insufficient mixing . . . . . . . . . . . . . . . 19

10. LOFT laser weld - penetrated $\mathrm{T} / \mathrm{C}$ sheets . . . . . . . . . . . . 19

11. LOFT instrumented guide tube assembly . . . . . . . . . . . 22

12. LOFT guide tube instrumentation assembly $\ldots \ldots \ldots$

13. LOFT guide tube instrumentation assembly . . . . . . . . . . . . 24

14. LOFT instrumented fuel bundle instrumentation

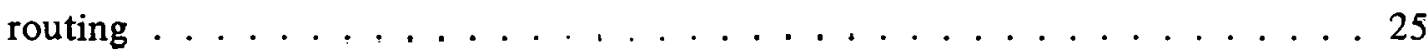

15. LOFT instrumented fuel bundle instrumentation

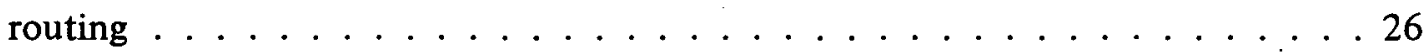

16. LOFT instrumented fuel bundle instrumentation

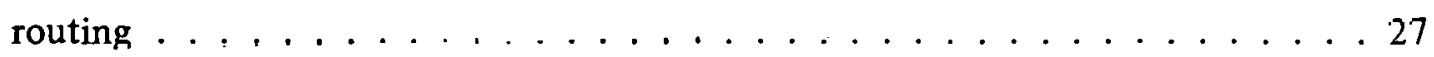




\section{TABLES}

I. Organizations Involved in LOFT Fuel Module

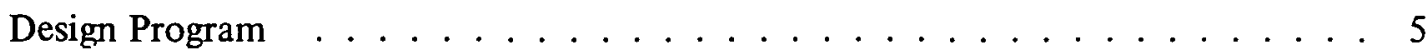

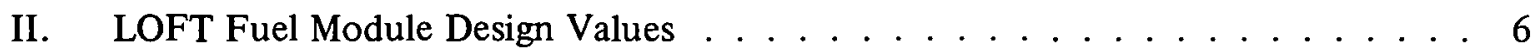

III. LOFT Fuel Module Thermal-Hydraulic

Design Program . . . . . . . . . . . . . . . . . . 29

IV. LOFT Fuel Module Structural Design Program $\ldots \ldots \ldots 33$

V. LOFT Fuel Module MIscellanteuus Design Activities . . . . . . . . . . 55

VI. I.OFT Fuel Bundle Fabrication Process

Qualifications/Demonstrations Program . . . . . . . . . . . . 57

VII. LOFT Fuel Module Special Inspection Technique

Process Demonstrations . . . . . . . . . . . . . . . . . 61

VIII. As-Built LOFT Fuel Bundle Characteristics to

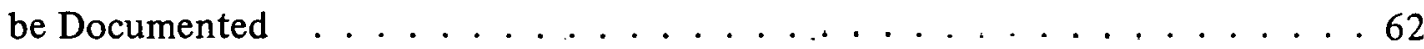

IX. LOFT Fuel Module Fabricators . . . . . . . . . . . . . . . 72

X. Loft Fuel Rod Thermocouple $\Lambda$ ttachment History . . . . . . . . . . . . 74 


\section{LOFT FUEL MODULES DESIGN, CHARACTERIZATION, AND FABRICATION PROGRAM}

\section{INTRODUCTION}

The loss-of-fluid test (LOFT) fuel modules have evolved from a comprehensive five-year design, characterization, and fabrication program which has resulted in the accomplishment of many technical activities of interest in pressurized water reactor fuel design development and safety research. This report summarizes the campaign highlights which include:

(1) Determination of fundamental high-temperature reactor material properties

(2) Design invention related to in-core instrumentation attachment

(3) Implementation of advanced and/or unique fuel bundle characterization techniques

(4) Implementation of improved fuel bundle fabrication techniques

(5) Planning and execution of a multimillion dollar design, characterization, and fabrication program for pressurized water reactor fuel.

\section{FUNCTIONS}

The general objectives of the LOFT Program are:

To evaluate the capability of analytical methods to predict the loss-of-coolant accident (LOCA) response of large pressurized-water. power reactors, the performance of the engineered safety systems, and the margins of safety inherent in that performance

To identify any unexpected events or thresholds not presently accounted for in the analysis of plant response or in the design of engineered safety systems.

To accomplish the stated objectives the LOFT facility must provide data that have been produced under environments and conditions representative of that which would occur in large pressurized-water power reactors during an LOCA. 
The LOFT core design evolved the core configuration shown in Figure 1. The test instrumentation design developed the following instrumentation to be attached to the fuel modules:

Instrumentation Item

(1) Fuel rod cladding thermocouples

(2) Guide tube thermocouples

(3) Core inlet coolant thermocouples

(4) Core outlet coolant thermocouples

(5) Core liquid level detectors

(6) Core inlet pressure taps

(7) Core outlet and upper plenum pressure taps

(8) Reactor vessel upper plenum pressure detectors

(9) Neutron flux scan tubes

(10) Neutron flux detectors

(11) Upper structure thermocouples

(12) FuAl module linear mntion detectors

(13) Core outlet flow detectors
Quantity

185

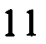

17

21

3

2

4

2

4

4

10

2

3

In addition to composing the reactor core and providing test instrumentation locations, the fuel modules also provide:

(1) The materials and geometry features which will assure that the important heat transfer, hydraulic,.mechanical, chemical, metallurgical, and nuclear behaviors are typical of those expected in large pressurized water reactors (LPWRs) during blowdown and emergency core coolant (ECC) injections

(2) The neutron absorber material needed; in conjunction with the borated water system, to control the reactivity of the LOFT core.

(3) A neutron source that will allow reactor startup with the neutron multiplication within the measurement capability of the reactor startup instrumentation. 


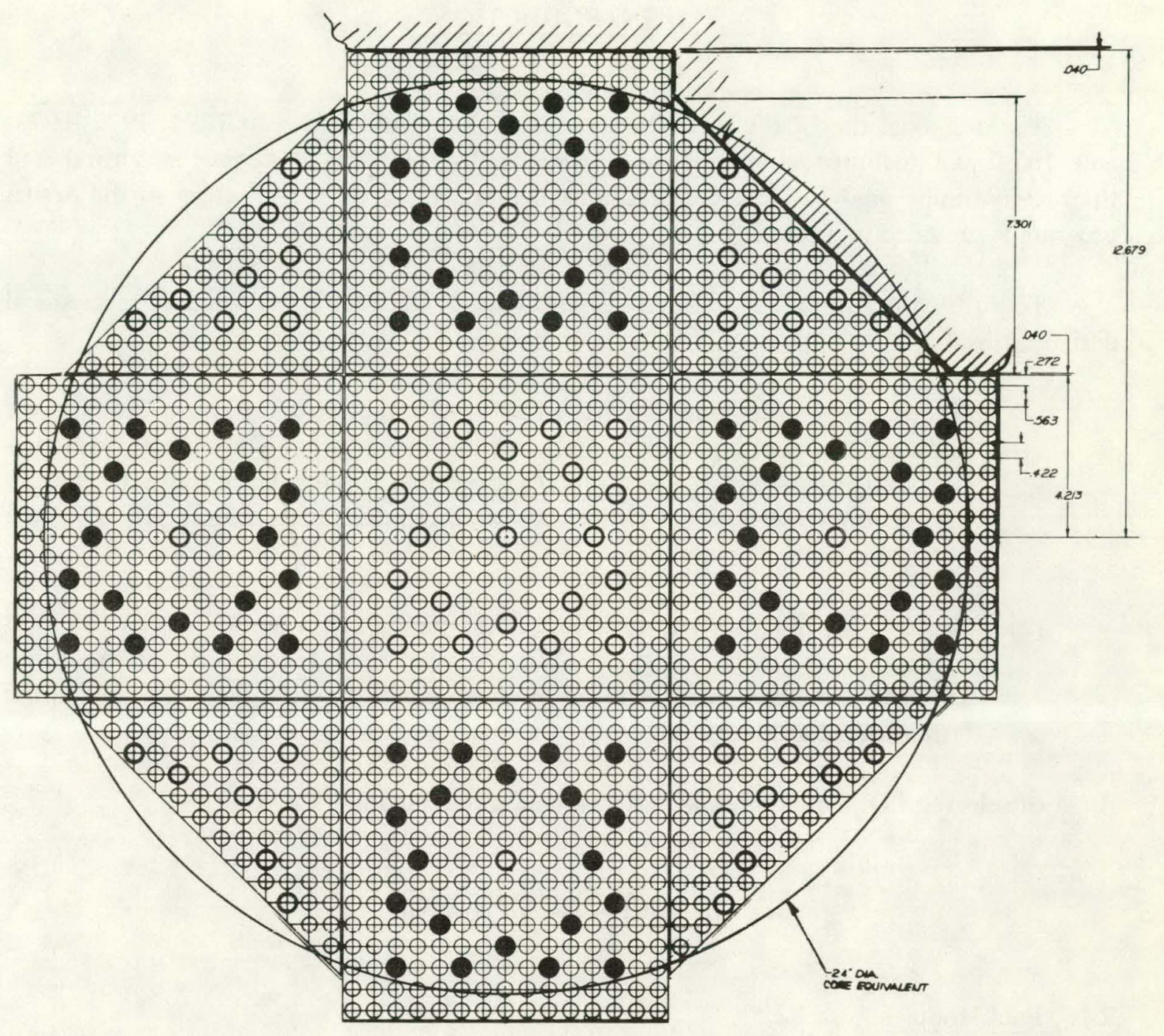

Poison Rod

Fig. 1 LOFT core layout. 


\section{DESIGN}

\section{INTRODUCTION}

The design of the LOFT fuel modules spanned the calendar years 1971, 1972, 1973, and 1974 and included comprehensive programs for mechanical design, structural and thermal-hydraulic analysis, and confirmatory testing. A list of contributors to the design program is provided in Table I.

To fulfill the functional and design requirements the LOFT fuel module mechanical design evolved:

(1) Modular-type units combining the basic fuel bundle (fuel rods, skeleton, spacer grids, guide tubes, end boxes, and control rods) with: (a) the test instrumentation detectors and cable leadouts, (b) an upper support structure extending to the reactor vessel top, (c) an instrumentation penetration assembly, and (d) the neutron source.

(2) Three basic design configurations: (a) the highly instrumented center (15 x 15 fuel rod array) module that does not contain control rods, (b) the control ( $15 \mathrm{x}$ 15 fuel rod array with control rod assembly) module, and (c) the corner (triangular-shaped) module.

A list of selected LOFT fuel module design values is provided in Table II.

\section{MECHANICAL DFSIGN}

\section{$2.1 \quad$ Fuel Modules}

The LOFT fuel module arrangements are shown in (a) Figures A-1 through -9 for center fuel modules, (b) Figures A-10 through -17 for control fuel modules, and (c) Figurcs A-18 through -30 for corner fuel modules. Figures A-1 through -30 are provided in Appen$\operatorname{dix}$ A.

The fuel module quantities are based on two core loads plus spares as follows:

(1) First core load consisting of fuel-module types as follows: one center (Type A), three instrumented controls (Type B), Iwo instrumented corncrs (Type C), one noninstrumented control (Type D), and two noninstrumented corners (Type E).

(2) A lot of spare fuel modules consisting of the following types: one center (Type A), one instrumented control (Type B), one instrumented corner (Type C), and 
TABLE I

ORGANIZATIONS ${ }^{[a]}$ INVOLVED IN LOFT FUEL MODULE DESIGN PROGRAM

\begin{tabular}{|c|c|c|c|c|c|c|c|c|c|c|c|}
\hline \multirow[b]{3}{*}{ Component } & \multirow{2}{*}{\multicolumn{2}{|c|}{ Mechanical }} & \multicolumn{2}{|c|}{ Thermal-Hydraulic } & \multicolumn{4}{|c|}{ Structural } & \multirow{2}{*}{\multicolumn{3}{|c|}{$\begin{array}{c}\text { Miscellaneous } \\
\text { Activities } \\
\end{array}$}} \\
\hline & & & \multirow{2}{*}{$\frac{\text { Analysis }}{\text { EG\&G ENC MPR }}$} & \multirow{2}{*}{$\frac{\text { Testing }}{\text { EG\&G ENC }}$} & \multicolumn{2}{|c|}{ Analysis } & \multicolumn{2}{|c|}{ Testing } & & & \\
\hline & $E G \& G$ & ENC MPR & & & EG\&G & ENC MPR & EG\&G & ENC & $\underline{E G \& G}$ & BMI & IITRI \\
\hline Fuel Rods & & $\sqrt{ }$ & $\checkmark$ & $\checkmark$ & & $\checkmark$ & & $\sqrt{ }$ & $\sqrt{ }$ & & \\
\hline Control Rods & & $\checkmark$ & $\checkmark$ & $\checkmark$ & & $\checkmark$ & & $\checkmark$ & $\checkmark$ & $\checkmark$ & \\
\hline Fuel Bundle Skeletcin & & $\checkmark$ & $\checkmark$ & $\checkmark$ & $\checkmark$ & $v^{\prime}$ & & $\checkmark$ & & & \\
\hline Upper Support Structure & $\checkmark$ & $\sqrt{ }$ & $\checkmark$ & $\checkmark$ & $\sqrt{ }$ & $\sqrt{ }$ & & & & & \\
\hline $\begin{array}{l}\text { Instrumentation } \\
\text { Penetration }\end{array}$ & $\checkmark$ & & $\checkmark$ & $\checkmark$ & $\checkmark$ & & $\sqrt{ }$ & & & & $\checkmark$ \\
\hline $\begin{array}{l}\text { Fuel Bundle Instrumen- } \\
\text { tation Support }\end{array}$ & & $\checkmark$ & $\checkmark$ & $\checkmark$ & & $\checkmark$ & & & & & \\
\hline $\begin{array}{l}\text { Upper Structure Instru- } \\
\text { mentation Support }\end{array}$ & $\sqrt{ }$ & $\sqrt{ }$ & & & $\sqrt{ }$ & $\checkmark$ & & & & & \\
\hline Neutron Source & & $\sqrt{ }$ & $\sqrt{ }$ & $\checkmark$ & & $\sqrt{ }$ & & $\checkmark$ & & & \\
\hline $\begin{array}{l}\text { EG\&G - EG\&G Idaho, Inc, } \\
\text { BMI } \text { - Battelle Columbus } \\
\text { ENC - Exxon Nuclear Comi } \\
\text { IITRI - Illinois Institut } \\
\text { MPR - MPR Associate, In } \\
\text { [a] ERDA (formerly AEC) }\end{array}$ & $\begin{array}{l}\text { Idah } \\
\text { Labo } \\
\text { pany, } \\
\text { e of } \\
\text { c., }, \text { W } \\
\text { parti }\end{array}$ & $\begin{array}{l}\text { Folls, I } \\
\text { oratories, } \\
\text { Richland, } \\
\text { Technology } \\
\text { Nashington, } \\
\text { icipated in }\end{array}$ & $\begin{array}{l}\text { Idaho } \\
\text { Columbus, Ohio } \\
\text { Washington } \\
\text { Research Insti } \\
\text { DC } \\
\text { the review of }\end{array}$ & $\begin{array}{l}\text { itute, Chic } \\
\text { the design }\end{array}$ & go, I & $\begin{array}{l}\text { llinois } \\
\text { am. }\end{array}$ & & & & & \\
\hline
\end{tabular}




\section{Mechanical Design Values}

Fuel Pellet

Fuel Material

Density, $\%$ of TD

Enrichment, w/o Fissile, Average

Diameter, in.

Length, in.

Dish

Dish Volume (total), \% of Pellet Volume
$\mathrm{UO}_{2}$ Sintered Pellets

$93.0 \pm 1.5$

$4.00 \pm 0.05$

$0.3659 \pm .0005$

$0.600 \pm 0.025$

Bulli Ends

2.0

Fuel Rod

Active Fuel Length, in.

Fuel Stack Density, \% TD

Diametral Pellet-to-Clad Gap, in.

Plenum Length, gross, in.

Cladding Material

Clad $0 D^{[a]}$, in.

Clad ID; in.

Clad Thickness, nominal, in.

Clad Thickness, minimum, in.

Weight, ib

Fuel Rundle

Number of Fuel Rods, square

Number of Fuel Rods, corner

Fuel Rod Array, square

Fuel Rod Array, corner

Fuel Rod Pitch, in.
$66.00 \pm 0.20$

91.1

$0.0075 \pm 0.002$

3.00

Zircaloy -4

$0.422 \pm 0.002$

$0.3734 \pm 0.0015$

0.0243

0.0228

3.06

204

70

$15 \times 15$

$12 \times 12$ triangular

0.563 
Mechanical Design Values (continued)

Fuel Rod Separation, nominal, in. $\quad 0.141$

Fuel Rod Separation, minimum, in. $\quad 0.120$

Fuel Bundle Length, in. $\quad 78.568$

Fuel Weight, $1 \mathrm{~b} \mathrm{UO}_{2} / 1 \mathrm{~b} \cup$ square assembly $511 / 450.3$

Fuel Weight, $1 \mathrm{~b} \mathrm{UO}_{2} / 1 \mathrm{~b} \mathrm{U}$ corner assemibly $175.4 / 154.5$

Spacers

Type

Egg-Crate - Integral Spring

Material

Incone 1718

Number per Bundle

5

Mechanical Integrity Bundle Average Design 30,000 Burnup, MWd/MTM

Core Data

Number of Fuel Bundles

9 (5 square -4 corner)

Number of Active Fuel Rods

1300

Neutron Source

Material

Cal i fornium-252

Strength (700 days after delivery)

$2 \times 10^{8} \mathrm{n} / \mathrm{sec}$

Control Rod Clusters

Poison Material

$80 \mathrm{Ag}-15 \mathrm{In}-5 \mathrm{Cd}$

Poison Rods per Cluster

20

Weight, $1 \mathrm{~b}$

87

Assembly weight, 1b

Fuel Bundle Type

Fuel Bundle

$\frac{A}{698} \quad$ B $\quad$ D $\quad$ E

Upper Support Structure

$\begin{array}{lllll}829 & 685 & 280 & 685 & 280\end{array}$

Fuel Module

$\begin{array}{lllll}1730 & 1730 & 800 & 1500 & 545\end{array}$ 
Thermal and Hydraulic Design Values

\begin{tabular}{|c|c|}
\hline $\begin{array}{l}\text { Reference Design Thermal Output, } \\
\text { (MWt)/Btu/hr }\end{array}$ & $55 / 1876 \times 10^{8}$ \\
\hline \multicolumn{2}{|l|}{$\begin{array}{l}\text { Effective Flow Rate for Heat Transfer, } \\
\text { lb/hr }\end{array}$} \\
\hline Maximum & $4.28 \times 10^{6}$ \\
\hline High & $3.42 \times 10^{6}$ \\
\hline Low & $2.77 \times 10^{6}$ \\
\hline System Pressure, nominal, psig & 2253 \\
\hline System Pressure, Design, psig & 2208 \\
\hline Average Power Density, kW/ 1 & $0,109.4$ \\
\hline Maximum Heating Rate, $\mathrm{kW} / \mathrm{ft}$ rated power & 19.0 \\
\hline Average Heating Rate, $\mathrm{kW} / \mathrm{ft}$ & 7.49 \\
\hline $\begin{array}{l}\text { Active Heat Transfer Surface, } \\
\mathrm{ft}^{2}\end{array}$ & 789.93 \\
\hline Maximum Heat Flux, (o Overpower) Btu/hr-ft ${ }^{2}$ & 644,830 \\
\hline Average Heat Flux, Btu/hr-ft ${ }^{2}$ & 231,400 \\
\hline Maximum $\mathrm{UO}_{2}$ Temperature, ${ }^{\circ} \mathrm{F}$ rated power & 4700 \\
\hline Maximum Fuel Rod Surface Temperature, ${ }^{\circ} \mathrm{F}$ & 664 \\
\hline MCHFR at Overpower Conditions ${ }^{[\mathrm{b}]}$ & $1.30($ low flow) \\
\hline \multicolumn{2}{|l|}{ Coolant Inlet Temperature, ${ }^{\circ} \mathrm{F}$} \\
\hline Maximum Flow & 562 \\
\hline High Flow & 557 \\
\hline Low Flow & 551 \\
\hline \multicolumn{2}{|l|}{ Design Power Peaking Factors } \\
\hline Heat Generated in Fuel, \% & 97.4 \\
\hline $\begin{array}{l}\text { Relative Fuel Bundle Power Factor plus } \\
\text { Local Power Peaking Factor }\end{array}$ & 1.573 \\
\hline
\end{tabular}


Thermal and Hydraulic Design Values

(continued)
Axial Power Peaking Factor
1.56
Total Nuclear Peaking Factor
2.45
Engineering Heat Flux Factor
1.03
Total Power Peaking Factor, $\mathrm{Fq}^{\mathrm{N}}$
2.53
[a] After etching.
[b] Based on W-3 correlation.

one center with zircaloy (instead of Type 304 stainless steel) guide tubes and pressurizable fuel rods (Type F).

(3) Core reload consisting of fuel module types as follows: one center (Type A), three instrumented controls (Type B), two instrumented corners (Type C), one noninstrumented control (Type D), and two noninstrumented corners (Type E). The reload fuel bundles also have pressurizable fuel rods.

The LOFT fuel modules include numerous examples of (a) mechanical design invention and/or development and (b) changes from contemporary design features, which are described in the following paragraphs.

\subsubsection{Fuel Rods.}

(1) End Cap Seal Welds - The weld configuration is a proprietary design geometry developed by the LOFT fuel supplier which has a high demonstrated reliability.

(2) Instrumented Fuel Rod Upper End Cap - See Subsection 2.1.7, Fuel Bundle Instrumentation Attachment.

(3) Pressurizable End Cap - The reluad and Type F fuel rods have a modified upper cap (see Figure 2) that allows the fuel rod to be pressurized to 800 psig maximum after fabrication of the fuel rods by a laser drilling and rèwelding technique.

(4) Thermocouple Attachment - See Suhsection 2.1 7, Fuel Bundle Inetrumentation Attachment. 


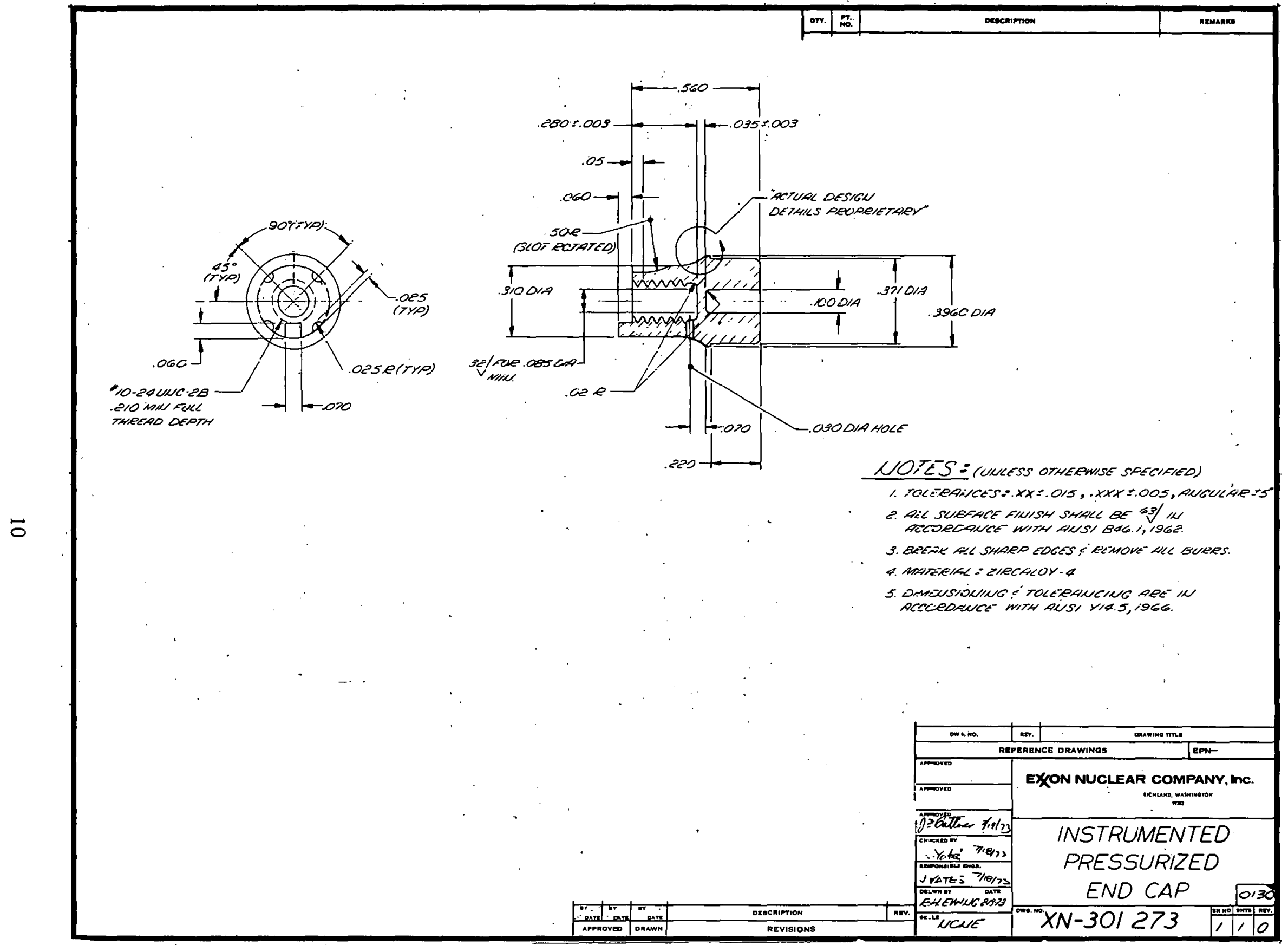

Fig 2 LOFT instrumented pressurized end cap. 
(5) Fuel Rod Assembly - The LOFT design configuration in conjunction with the supplier's proprietary comprehensive fabrication quality assurance programs is expected to provide exceptional reliability characteristics based on the supplier's fuel rod reliability record.

\subsubsection{Spacer Grids.}

(1) Intersection Joining Method - The LOFT spacer grids (see Figure 3) feature a TIG welded intersection joint compared to the brazed joints of contemporary designs. The technique is judged to provide design improvements in dimensional control and joint reliability although strength testing during the design development indicated that for tensile loading along the joint axis the welded joint was $40 \%$ weaker than a brazed joint. The structural design program (see Table IV) indicated that the additional strength of the brazed construction was not necessary for achieving the design objectives.

2.1.3 Skeleton (subassembly consisting of spacer grids, guide tubes, and end boxes).

(1) Triangular Skeleton Alignment - The triangular shape causes the control of twist and lean (runout from true position) to be difficult. The fabrication experience resulted in improvements to the fuel bundle assembly fixtures design and assembly instructions to achieve the triangular-shaped skeleton alignment objectives.

\subsubsection{Control Rods.}

(1) The control rod spiders (see Figure 4) were designed to be machined from forgings instead of the contemporary construction by brazing the fingers to the hub. Fabrication problems that were experienced included (a) unexpected porosity of the raw material even though satisfactory precautionary ultrasonic examination of the raw material had been performed, and (b) surface roughness above specified values. The solid spiders are considered to yield improvements in reliability compared to the contemporary construction.

2.1.5 Upper Support Structures (upper support structures provide lateral and holddown support for the fuel bundles).

(1) Lateral Support - The lateral support is accomplished by achieving a close fit at three locations: the upper structure lower extremity and immediately above and below the reactor vessel nozzles. The close fit (room temperature ) is approximately 0.010 inch between mating surfaces at the lower extremity and 0.055 inch between the mating surfaces adjacent to the nozzles. This lateral support is designed to provide the following features: 


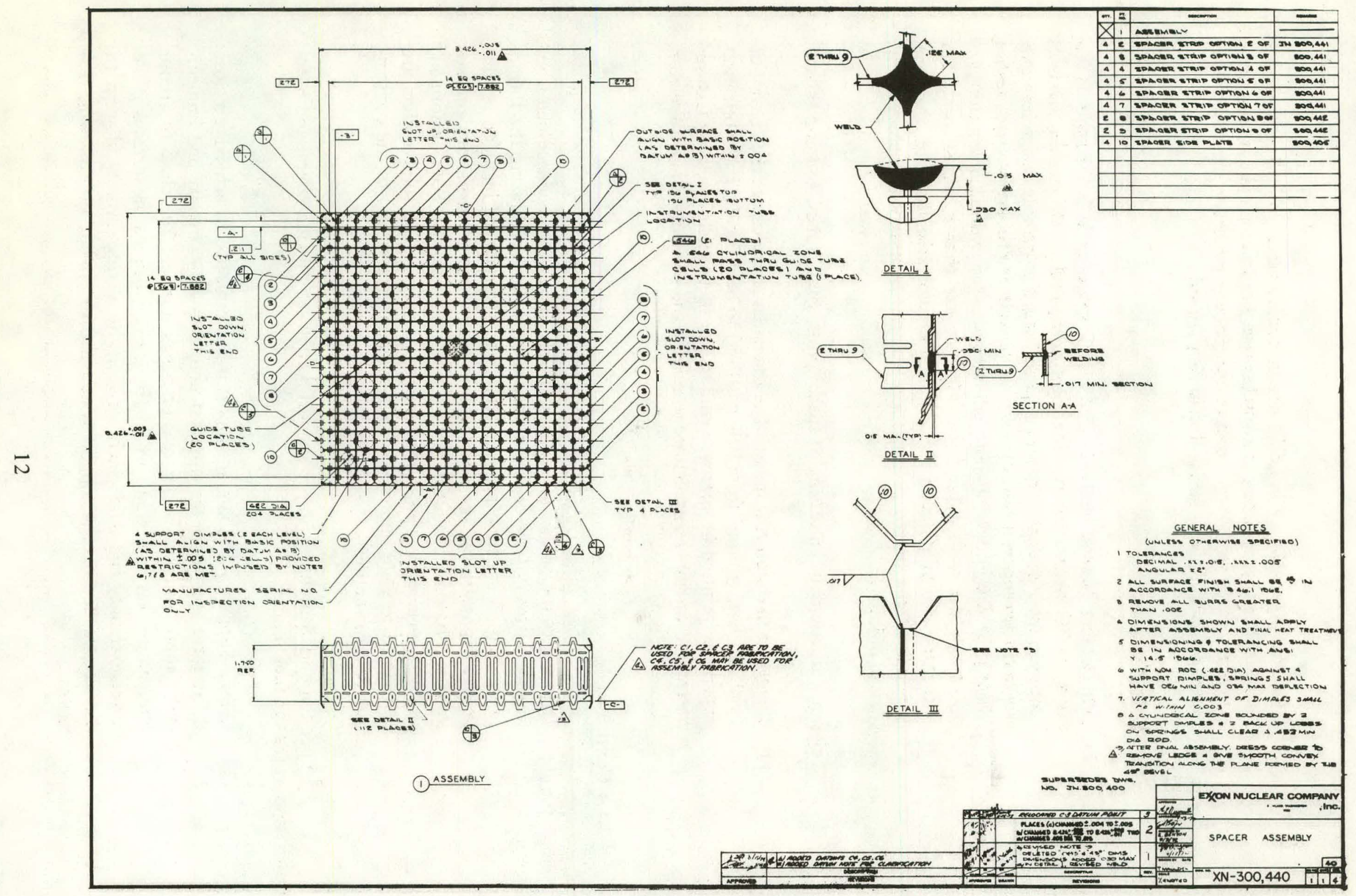

Fig. 3 LOFT $15 \times 15$ spacer grid. 


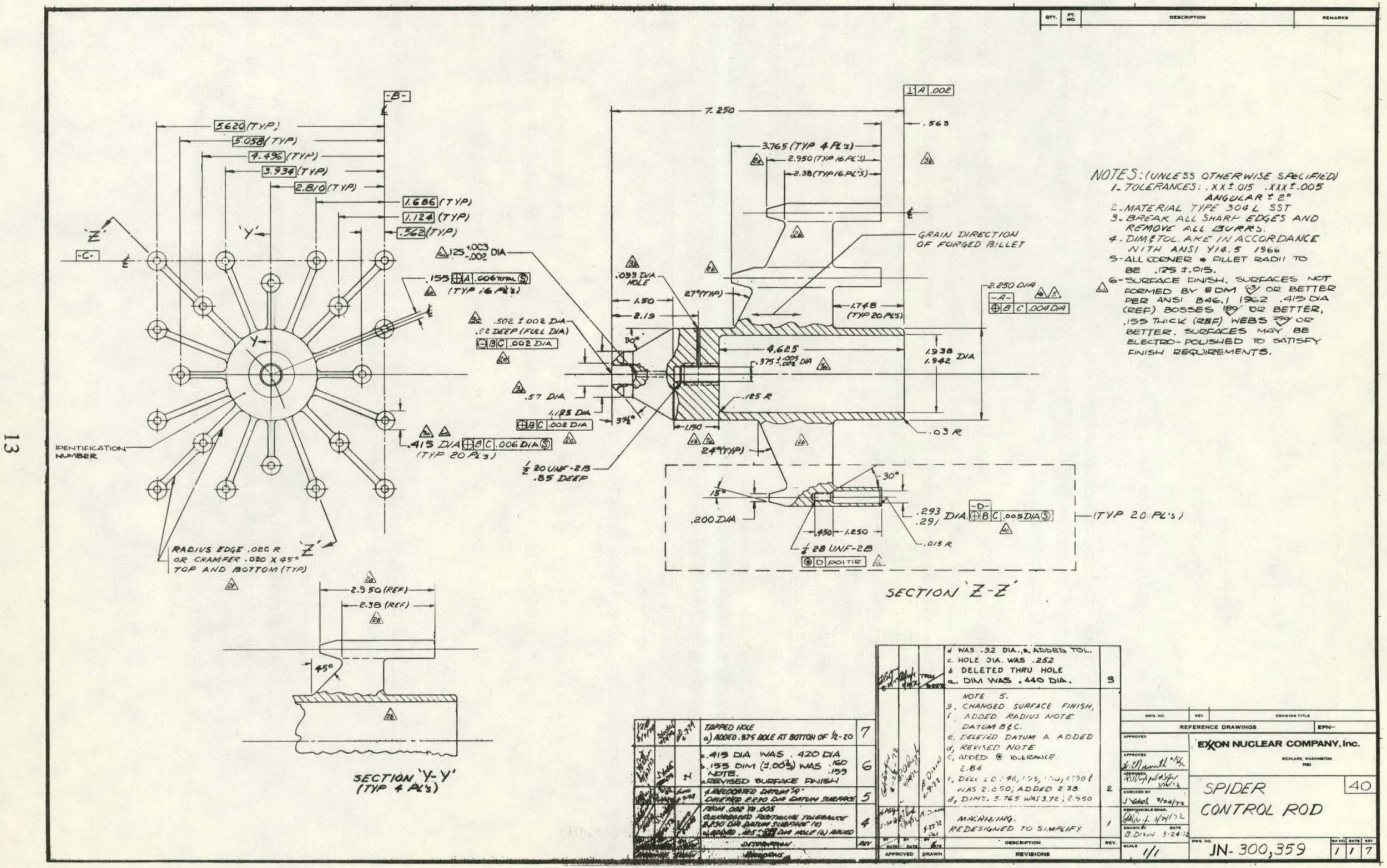

Fig. 4 LOFT control rod spider. 
(a) Prevention of fuel module vibration during normal operation

(b) Maintenance of allowable stress limitations during (LOCE) subcooled blowdowns

(c) Noninterference during core loading.

Details of this design development are described in MPR letter report "Lateral Clearances for Fuel Module Upper Support Structures and Interfacing Components”, May 24, 1972.

(2) Holddown - The fuel bundle holddown is accomplished by a combination of upper structure dead weight and coil-holddown springs. The coil spring force-deflection characteristics are designed to prevent the exceeding of allowable fuel bundle stress limitations during normal, transient, and planned LOCE plant operations.

2.1.6 Instrumentation Penetration. The Instrumentation Penetration (see Figure A-9, $-10,-11,-12,-17,-20,-21,-22,-28,-29,-30)$ provides the primary coolant pressure boundary penetration for the LOFT fuel module instrumentation. The LOFT design objectives are (a) high efficiency in area for making the individual cable or tube seals (140 cables and 2 tubes in a 7 -inch diameter and 40 cables and 4 tubes in a 4-inch diameter), (b) high-pressure boundary reliability, and (c) leakproof seals between dissimilar metals (titanum to Inconel, carbon steel to Inconel, and stainless steel to Inconel). The special design features that achieve these objectives are as follows:

(1) High Seal-to-Area Efficiency - Each penetration uses three or more individual buttons (see Figure 5) which (a) can accommodate up to approximately 35 instrument cables, (b) are brazed to the instrument cable or tube, and (c) are welded to the instrumentation penetration body (pressure plate).

(2) High-Pressure Boundary Reliability - Each penetration fcatures two seals in series for increased pressure boundary reliability.

(3) Titanium to Inconel Seal - The pressure boundary scal between the titanium-sheathed thermocouples and Inconel penetration is accomplished using an explosion bonded titanium - tantalum-Inconel sandwich material button that is brazed to the themocouple using a titanium - zirconium beryllium filler metal and TIG welded to the Inconel penetration. 


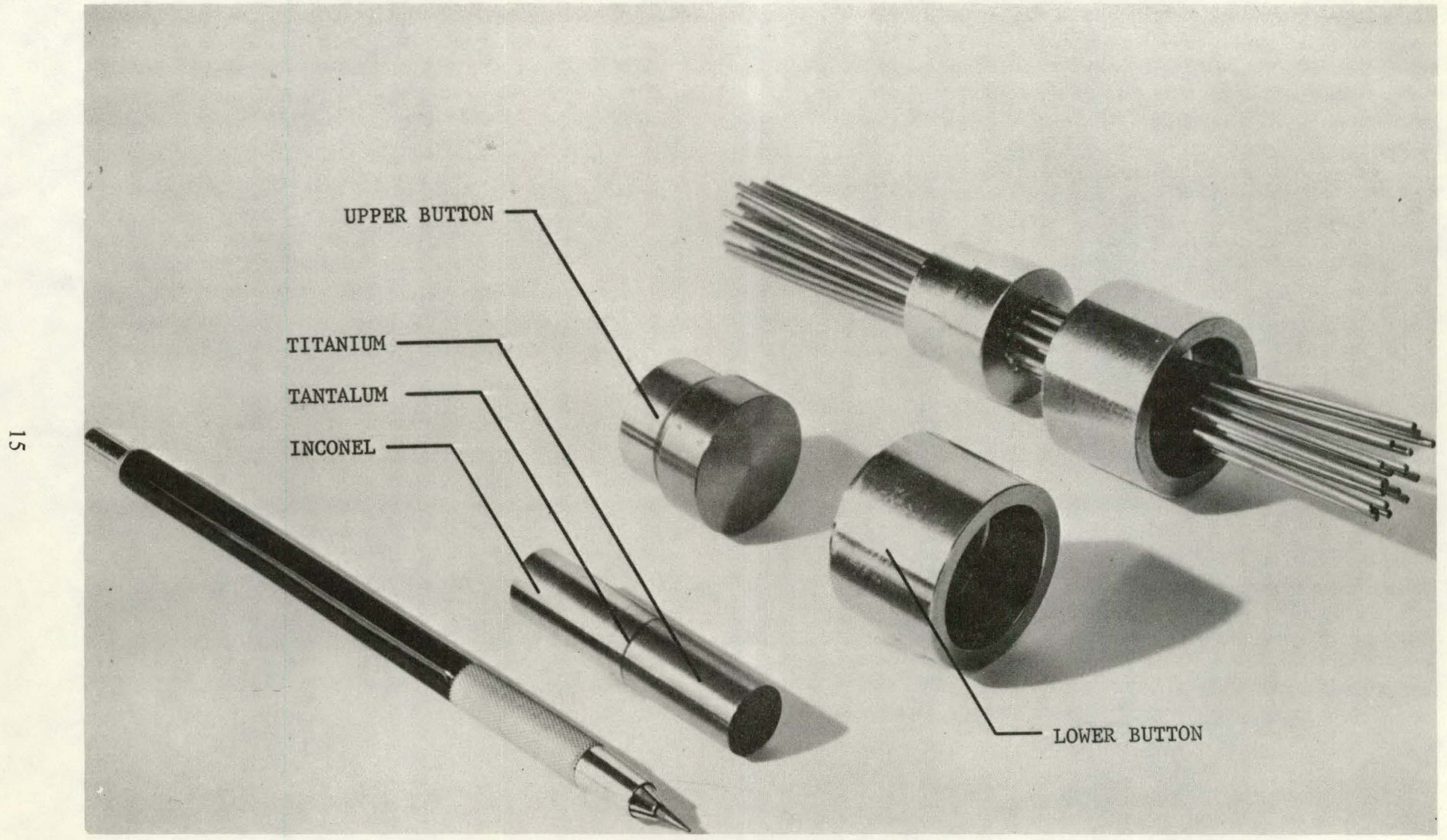

Fig. 5 LOFT braze button. 
Selection of the braze material was based on an extensive brazing material evaluation which included selection of a satisfactory brazing filler material from seven candidate materials. This evaluation is described in IITRI report "IITRI-B6112-1, Evaluation of Brazing Filler Metals for C.P. Titanium Reactor Instrumentation Components", October 20, 1971. Process demonstrations have indicated this design will be successful.

(4) Stainless-Steel-to-Inconel Seal - The pressure boundary seal between the stainless-steel-sheathed instrument cables and Inconel is accomplished with a gold-nickel filler metal braze of the instrument cable to the Inconel button and TIG weld between button and penetration.

(5) Inconel-to-Carbon Steel-The pressure boundary seal between the instrumentation penetration and reactor vessel head is accomplished using $\mathrm{K}$-seal type mechanical seals which were chosen over O-rings because they were judged to provide increased reliability for this service condition.

\subsubsection{Fuel Bundle Instrumentation Attachment.}

(1) Thermocouple Attachment - The LOFT design features titanium-sheathed thermocouples attached to the outside of zircaloy-clad fuel rods (see Figure 6) by laser welding using titanium filler wire. Titanium was selected over zircaloy because the technology for satisfactory fabrication of the small diameter zircaloy-sheathed thermocouples had not been developed. Noteworthy features of the weld design are as follows:

(a) Alloy-Mixing - The mixing between titanium and zircaloy is precisely controlled for a compromise between strength enhancement obtained from high-mixing and corrosion resistance resulting from luw-mixing. The photomicrographs show acceptable (Figurc 7) and unacceptable (too-high and too-low) (Figures 8 and 9) mixing characteristics.

(b) Heat-Affected Zone - The fragile thermocouple sheath (0.009 inch thick) heat-affected zone is precisely controlled to prevent penetration of the sheath during welding. The photomicrographs show an acceptable penetration condition (Figure 7) and results of reaching the thermocouple insulator $(\mathrm{MgO})$ with the melt zone (Figure 10).

(c) Weld Spacing - The individual weld nuggets, consisting of eight overlapping laser spots, are spaced at approximately 0.8 -inch intervals to allow for differential thermal expansion between the zircaloy and titanium at temperatures expected during $\mathrm{LOF}^{\prime \prime} \mathrm{I}^{\prime}$ experiments. 


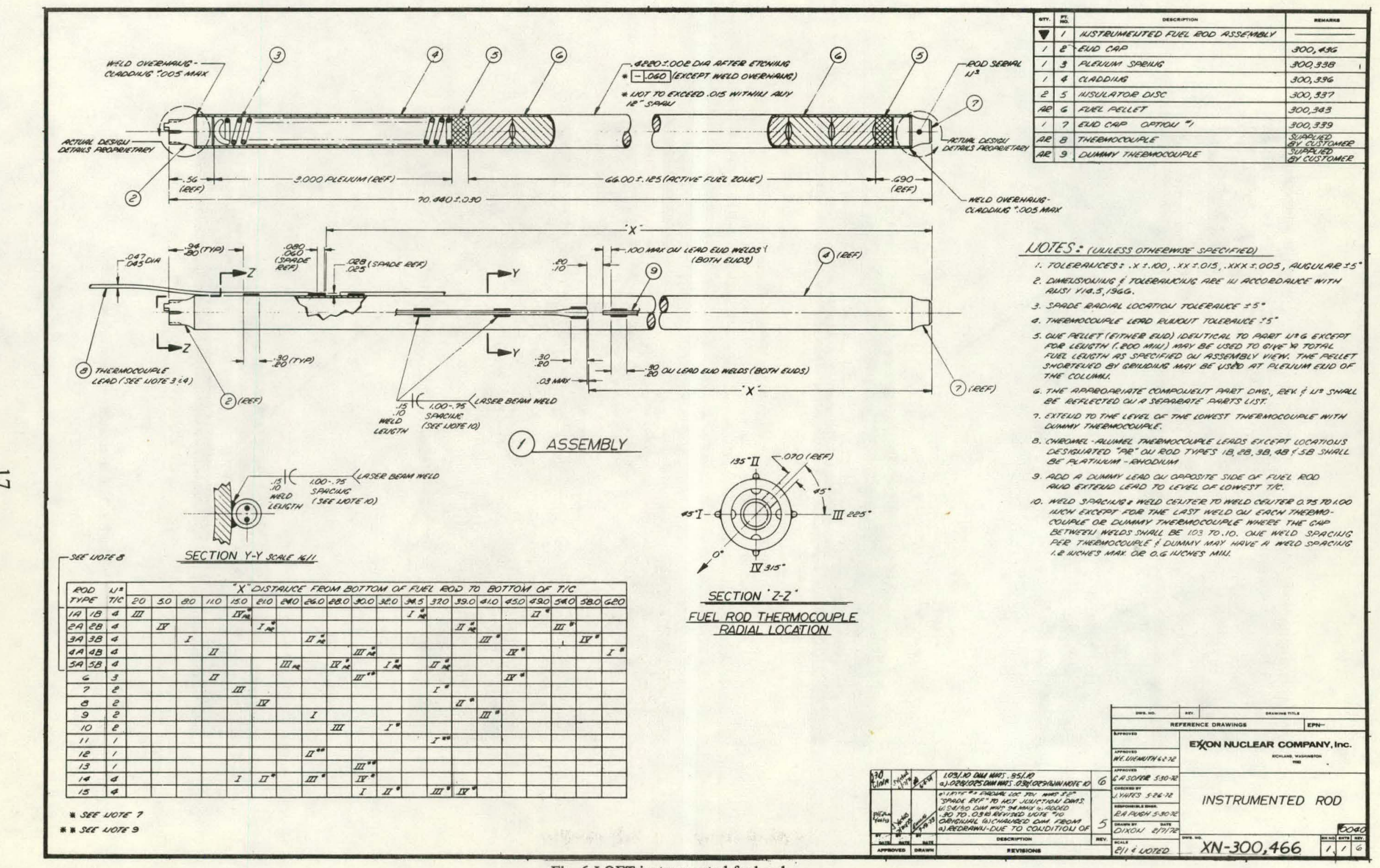

Fig. 6 LOFT instrumented fuel rod. 


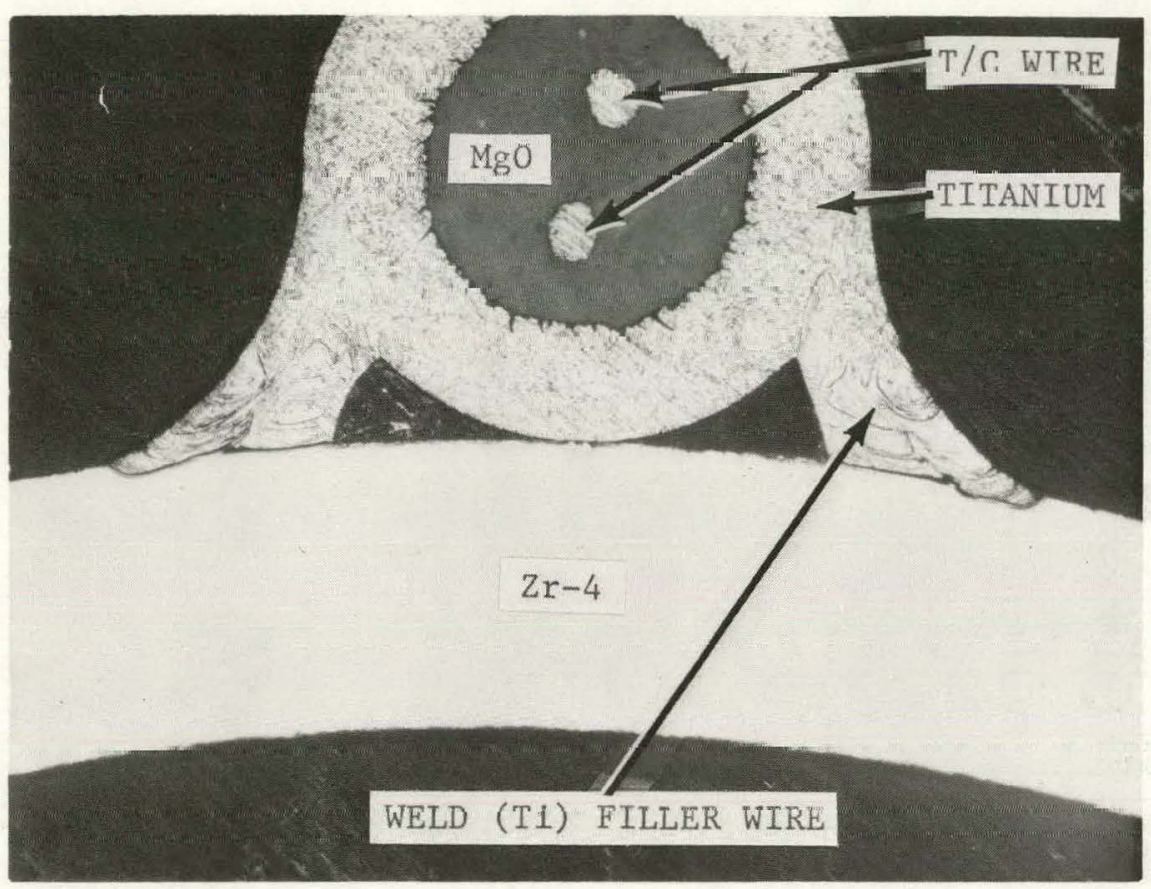

Fig. 7 LOFT laser weld - acceptable mixing.

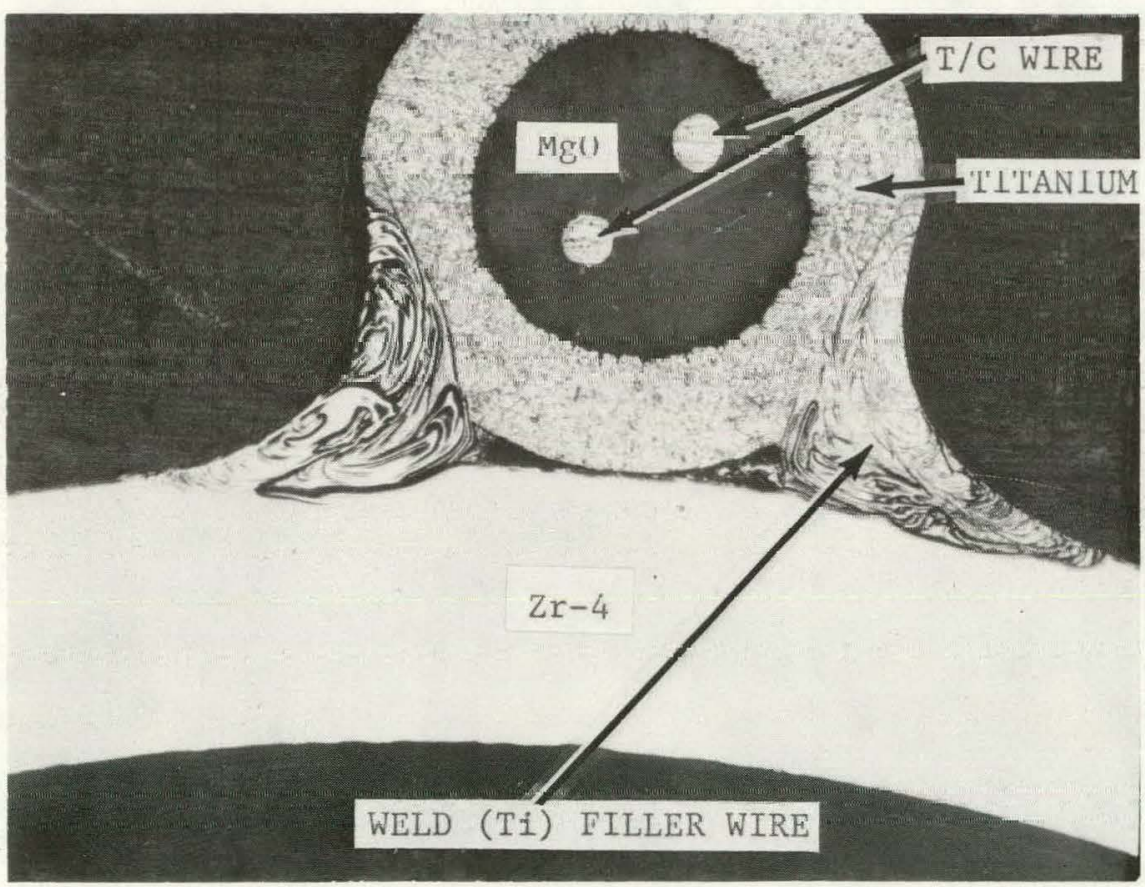

Fig. 8 LOFT laser weld - too much mixing. 


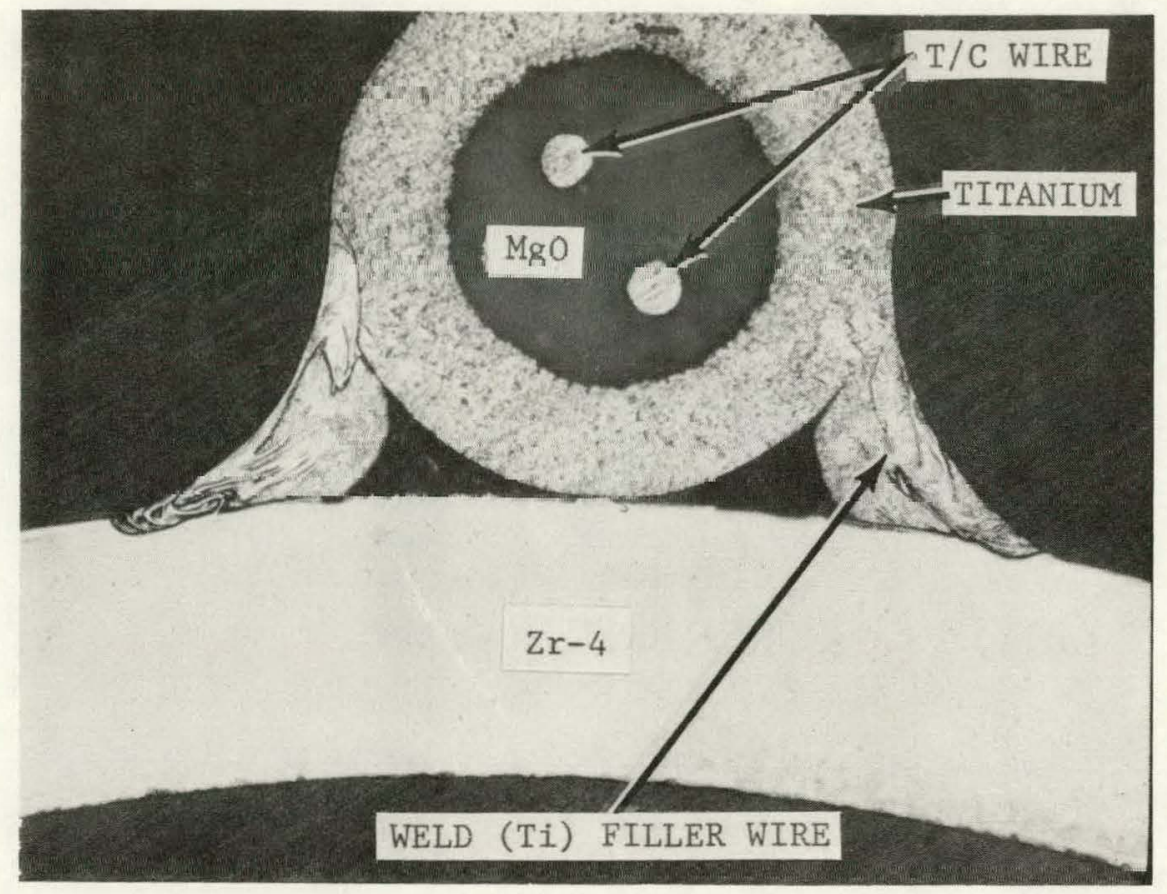

Fig. 9 LOFT laser weld - insufficient mixing.

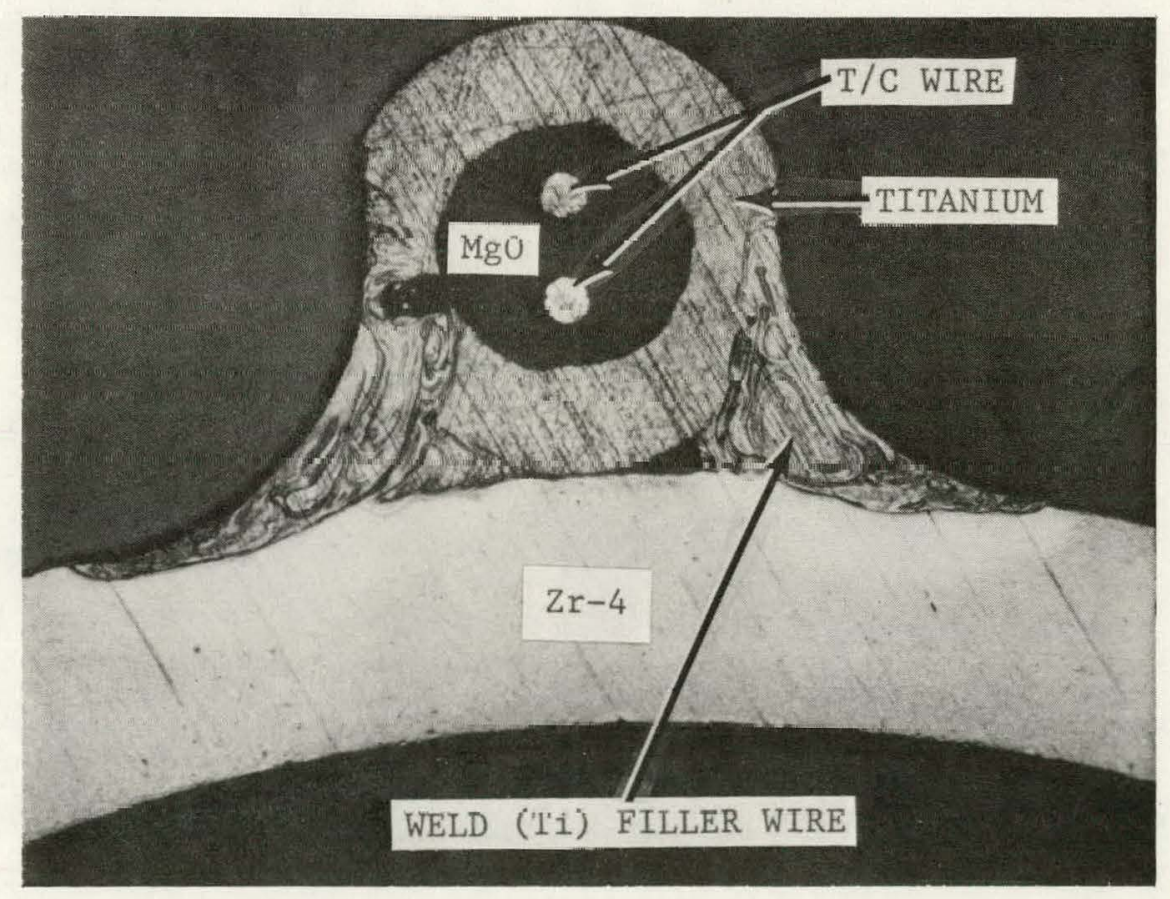

Fig. 10 I.OFT laser weld - penetrated T/C sheets. 
Thermal cycling and corrosion testing of the design indicate that the weld design will provide the following expected lifetimes:

Exposure to reactor coolant conditions $\left(650^{\circ} \mathrm{F}\right.$ and 2300 psig): 6000 hours.

Thermal cycles:

$\begin{array}{ll}400 \text { to } 1100^{\circ} \mathrm{F} & (1 \text { cycle }) \\ 400 \text { to } 1400^{\circ} \mathrm{F} & \text { (5 cycles) } \\ 400 \text { to } 1500^{\circ} \mathrm{F} & \text { ( } 5 \text { cycles }) \\ 400 \text { to } 1700^{\circ} \mathrm{F} & \text { ( } 5 \text { cycles })\end{array}$

(2) Guide Tube Instrumentation Assembly - The LOFT fuel bundle design requires attachment of thermocouples to the guide tubes, locating fixed flux detectors inside the guide tubes, and routing lower end box coolant thermocouples inside the guide tubes in a manner that will satisfy the following design conditions:

(a) Differential Pressure Conditions - The components must withstand a differential pressure loading of 300 psi taken in the most adverse direction across each component, instrument, or mounting device, etc. The 300-psi loading requirement shall be evaluated assuming the same thermal conditions that exist at reactor full power $(55 \mathrm{MWt})$.

(b) Temperature Conditions

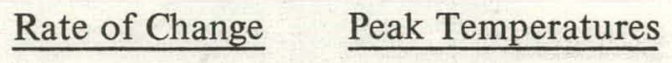

Zircaloy components at $675^{\circ} \mathrm{F}$ normal steady state operating conditions

Components attached to $20^{\circ} \mathrm{F} / \mathrm{sec}$ $2100^{\circ} \mathrm{F}(15$ support tubes cycles only) (guide tubes) 
Rate of Change $\quad \underline{\text { Peak Temperatures }}$

Components attached to

$20^{\circ} \mathrm{F} / \mathrm{sec}$

$900^{\circ} \mathrm{F}(15$

fuel assembly end boxes

cycles only)

(c) Transient Termination - After five seconds at the maximum temperature, the instrumentation shall be assumed to be quenched by immersion in a saturated steam-water mixture at a pressure of 25 psia.

Exxon invented a design (see Figures 11, 12, and 13) consisting of a system of coiled instrument cables, intermediate supports, and precise positioning of thermocouple spades to satisfy the design conditions and instrument location requirements.

(3) Instrument Cable Routing - The instrument cable routing features continuous protection of the cables from hydraulic buffeting and differential pressures: Figures 14, 15, and 16 show the cable routing in the center fuel bundle. Some significant features include:

(a) The thermocouple cable transition from fuel rod to upper tie plate (Figure 16) in a manner that minimizes exposure to high-velocity coolant and eliminates cable flexing during thermal cycling by machine-screw fastening the instrumented fuel rods to the upper tie plate. The fuel rod end cap and tie plate are fluted for passage of the thermocouples.

(b) The thermocouple routing protection across the tie plate surface provided by recessed channels and cover plates.

(c) Instrument cable routing protection up the end box sides provided by compact bundles of straight cables clamped at close intervals by staples which are match fit, lightly pressed against the cable bundle, and protruding staple ends welded to the end box from the outside (see Figure 16). The development of this design included consideration of unsatisfactory experiences with crossing cables underneath the cable clamp and sharp or protruding cable clamp edges.

(d) Routing paths for the instrument cables have generous radii on all edges, avoiding unsatisfactory experience with sharp edges in contact with the fragile instrument cable sheaths. 


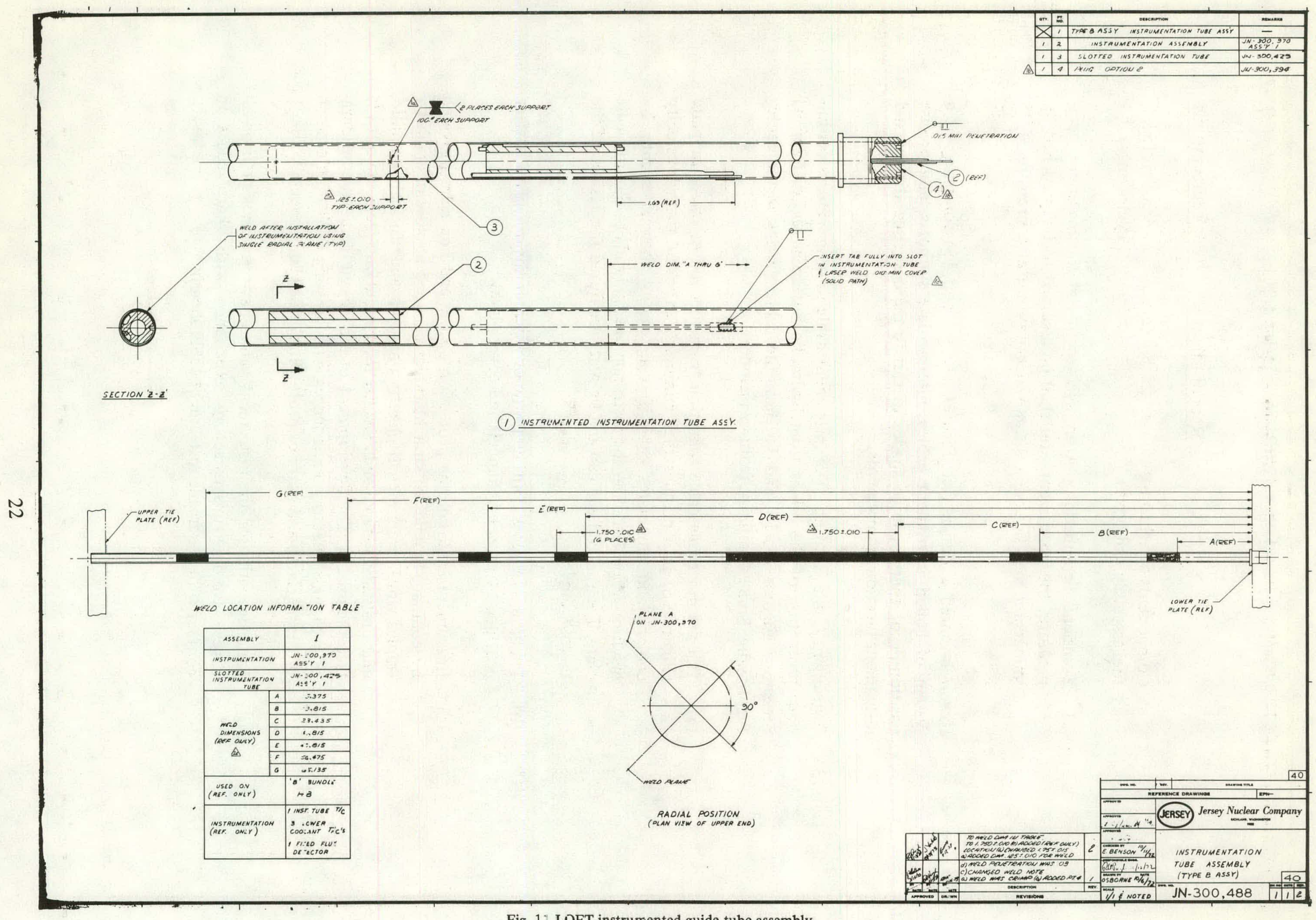

Fig. 11 LOFT instrumented guide tube assembly. 


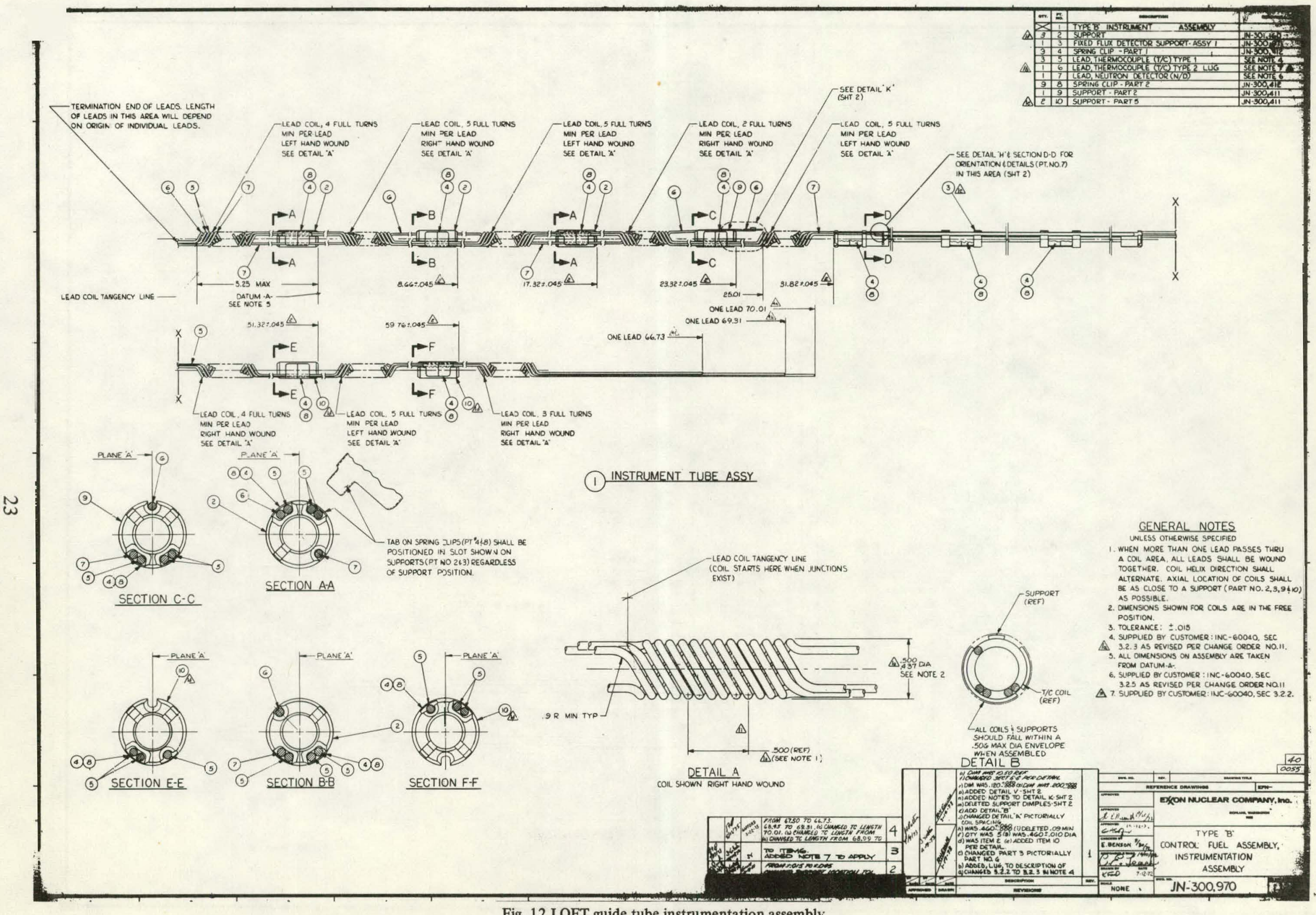

Fig. 12 LOFT guide tube instrumentation assembly. 


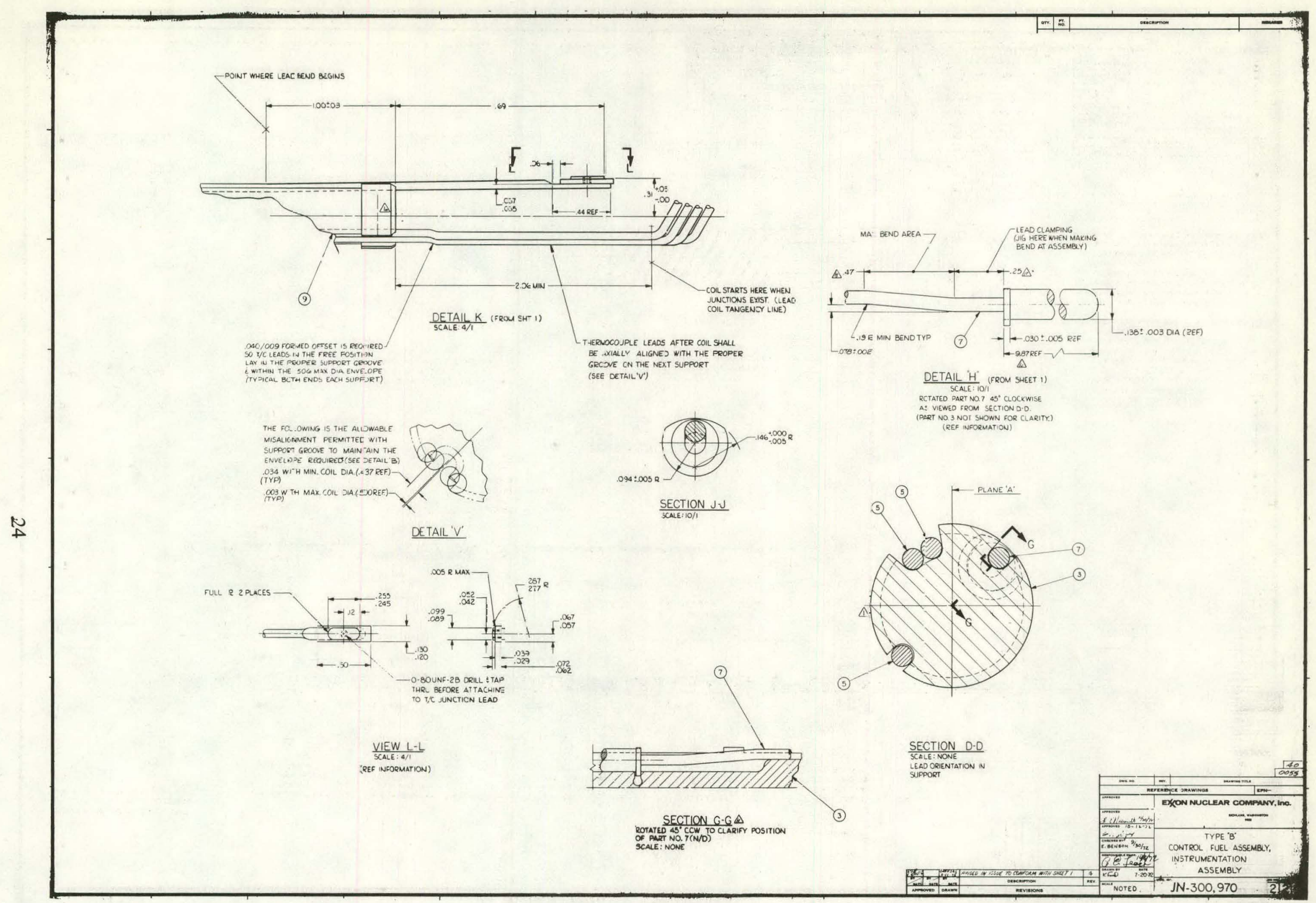

Fig. 13 LOFT guide tube instrumentation assembly. 


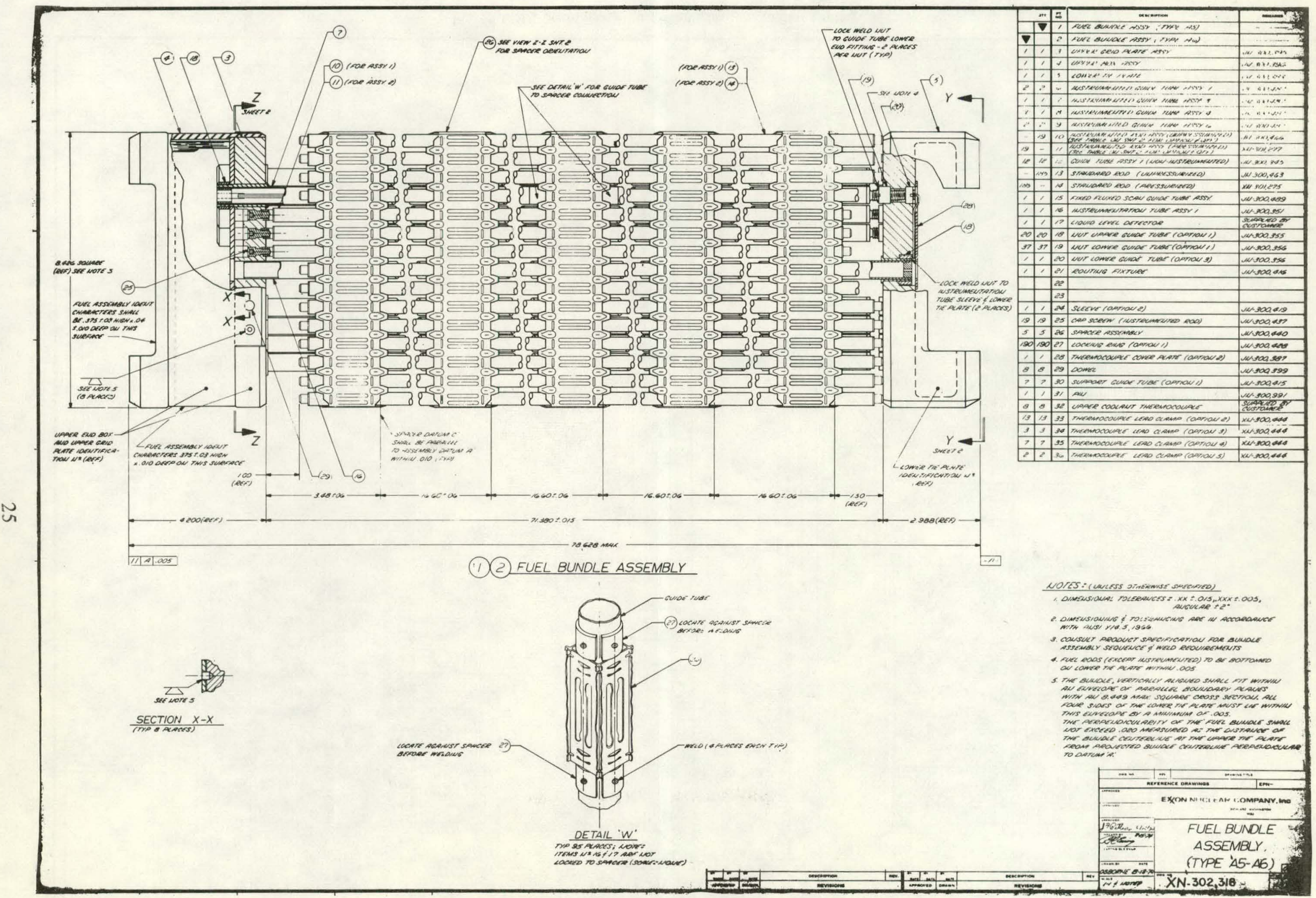

Fig. 14 LOFT instrumented fuel bundle instrumentation routing. 


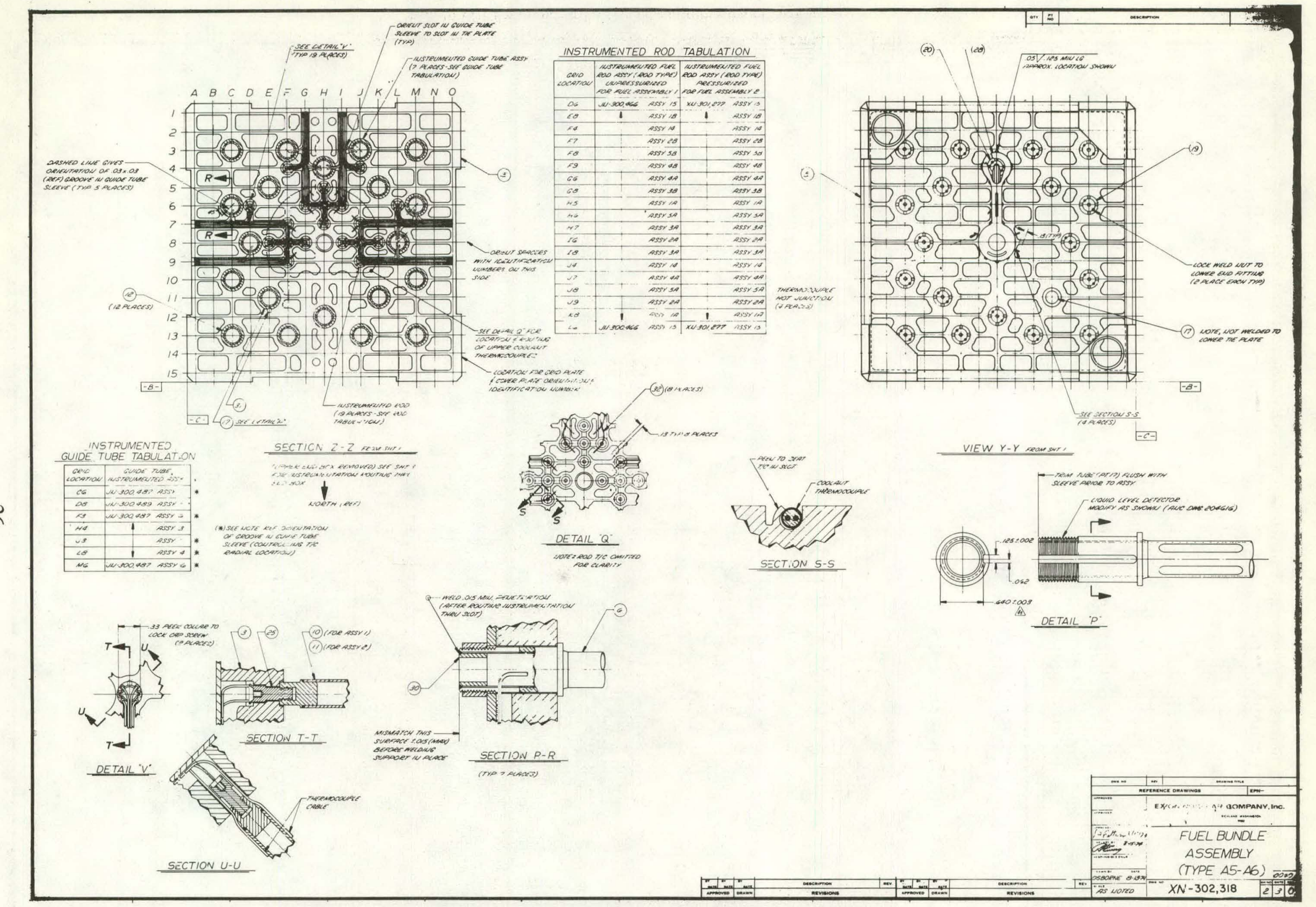

Fig. 15 LOFT instrumented fuel bundle instrumentaton routing. 


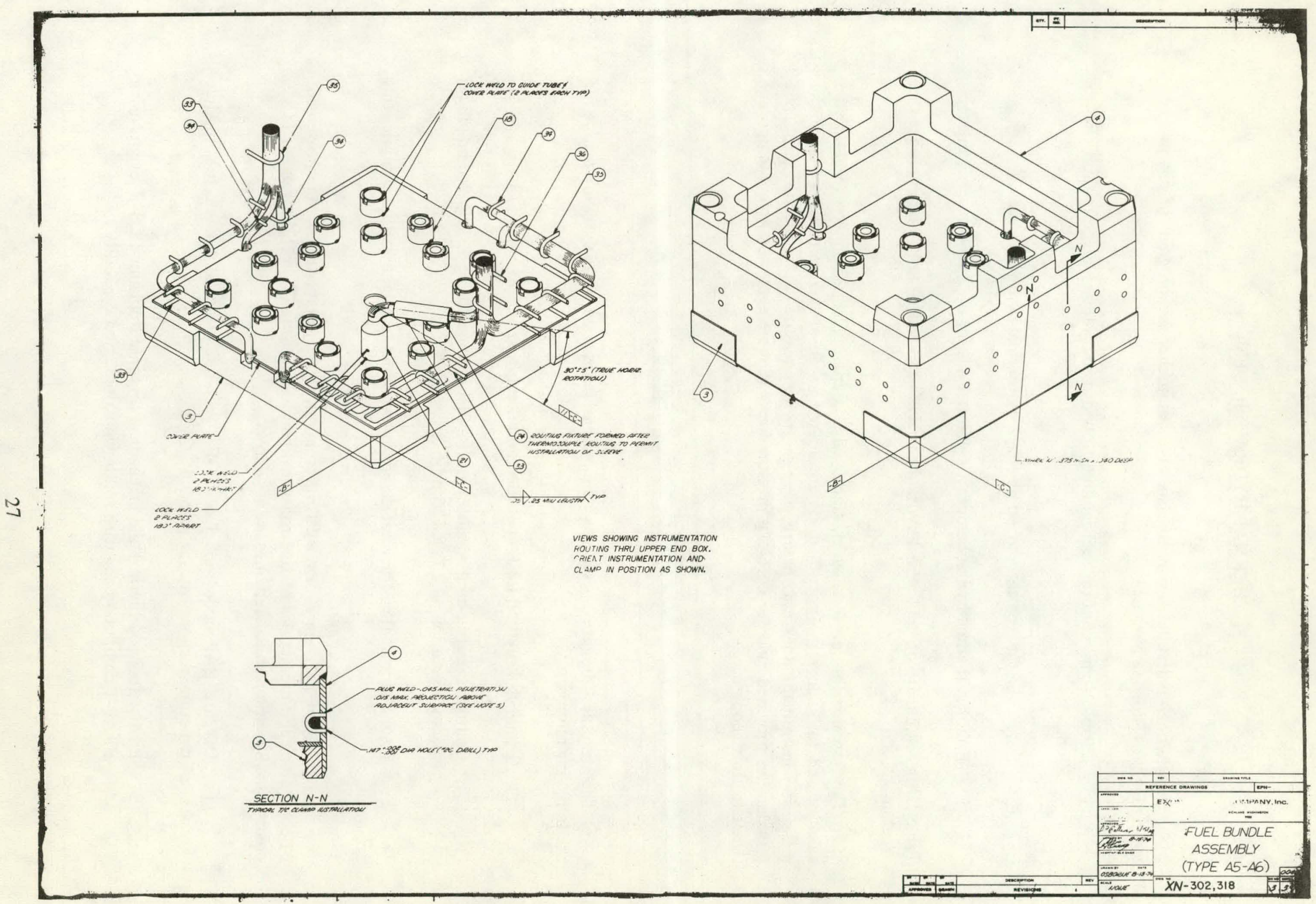

Fig. 16 LOFT instrumented fuel bundle instrumentation routing. 


\section{THERMAL-HYDRAULIC DESIGN}

The thermal-hydraulic design consists of a comprehensive program of analysis and testing for the following purposes:

(1) Establish and confirm fuel module flow distribution and pressure drop characteristics

(2) Determine fuel rod thermocouple effect on thermal-hydraulic behavior

(3) Estahlish thermal-hydraulic operating limitations for the LOFT fuel modules.

Table III is a summary of the thermal-hydraulic analysis and testing tasks that comprise this program.

The flow distribution test, which employed a laser-Doppler velocimeter to obtain the velocity and turbulence intensity data, is considered an advance in technology since the measuring instrument does not disturb the flow being measured. The pressure drop test program has provided data for core exit pressure losses that are applicable to contemporary core exit flow geometries.

\section{STRUCTURAL DESIGN}

The structural design consists of a comprehensive program of analysis and testing for the following purposes:

(1) Establish structural loading of fuel modules during LOCEs

(2) Confirm the structural adequacy of the fuel module during anticipated handling, reactor operation, and LOCE conditions.

Table IV is a summary of the struclural design analysis and testing tasks that comprise this program.

A continuing program is planned for development, use, evaluation, and improvement . of computer code predictions of fuel rod and fuel module structural behavior under LOCE conditions. Specific planned activities are as follows:

(1) Develop SAP code modcl of LOFT fuel modules and predict fuel module structural response during planned LOCE events

(2) Predict fuel rod thermal and mechanical response to planned LOCE events using FRAP-T computer code with rod bowing prediction capability 
TABLE III

LJFT FUEL NODULE THERMAL-HYDRAULIC DESIGN PROGRAM

\section{Purpose}

\section{A. Pressure Drop}

1. Preliminary predictions of LOFT fuel bundle pressure trop for use in LOFT primary system and fuel module upper support structure design.

2. Prediction of upper strusture pressure drop for use in LOFT primary system desiçn.

3. Jressure drop test data from flow distritution test.

\section{Pressure drop test data from} Type A \& C fretting corrosion test. 5. Pressure drop test data from ified Type $A$ \& $C$ fretting corrosion test bundles.

\section{Performing}

Organization

ENC

MPR

ENC

(Battelle

Nortrwest

Laboratories)

ENC

EMC
Results

The analysis predicted total fuel bundle flow loss coefficient of 6.62 (14.6 psi flow loss coefficient of 6.62 ( 14.6
at $2.45 \times 10^{6} \mathrm{lb} / \mathrm{hr}^{-\mathrm{ft}^{2}}$ flow rate).

The analysis predicted upper structure pressure drop of 5.5 psi at $3.1 \times 10^{6}$ $1 \mathrm{~J} / \mathrm{hr}-\mathrm{ft}^{2}$.

Testing results indicated spacer grids flow loss coefficient to be 3.65 (5 grids) compared to the predicted value of 3.53 .

Test results indicated significant pressure drop mismatch between Type A \& C fuel bundles at core exit and total fuel bundle flow loss coefficient of 8.55 for Type A and 9.74 for Type B.

Test results indicated acceptable improvement in core exit pressure drop provement in. core exit pressure drop mismatch of Type $A, B$, and $C$ fuel bundles after the design changes to Type A \& $C$ components. Measured flow loss coefficients were:

\begin{tabular}{|c|c|c|c|}
\hline & $\begin{array}{l}\text { Inlet } \\
\text { Flow* }\end{array}$ & $\begin{array}{c}\text { Fuel } \\
\text { Burdie }\end{array}$ & $\begin{array}{c}\text { Upper } \\
\text { Structure }\end{array}$ \\
\hline $\begin{array}{c}\text { Type A } \\
\text { Type B } \\
\text { Type C } \\
\text { Core }\end{array}$ & $\begin{array}{l}3.00 \\
3.00 \\
3.41\end{array}$ & $\begin{array}{l}5.62 \\
5.62 \\
5.265\end{array}$ & $\begin{array}{l}7.35 \\
7.29 \\
8.20\end{array}$ \\
\hline Average & 3.105 & 5.53 & 7.55 \\
\hline
\end{tabular}

* Includes core mounting plate.
Documentation

Exxon report, "Preliminary Pressure Drop Calculations for Jersey Nuclear LOFT Fuel Assembly", January 6, 1971.

MPR report, "Upper Plenum Pressure Drop", MPR-316, Volume II, Appendix G, December $22,1971$.

Exxon report, "XN-74-53, Anaiys is of the LOFT Instrumented Fuel Assembly Flow Distribution Experiments", October 15 , 1974.

Exxon report, "XN-75-61, Hydraul ic Performance of LOFT Fuel Assemblies, Volumes I \& II, June 1976.

Same as above. 
TA3LE III (continued)

Performing

Organization

Purpose

B. Flow Distribution

1. Determine fuel bundle flow distribution characteristics in region of high therral flux (inle:)

2. Determine core inlet flow dis tribution from reactor vessel ower plenum flow tests using a $2 / 3-s c a l e$ model.

3. Prediction of maximum fidid velocities in the core and spper
C. Thermal Mixing - Determine LOFT thermal mixing coefficients.

\section{Departure from Nucleate Boiling (DNB):}

1. Preliminars prediction of LOF fuel bundle DNB behavior for use

in fuel bundle warranty limitations.

2. DNB test data to confirm that the LOFT fuel bundle with thermocousles provided the same DNE behavior as fuel bundles withcut thermocouples.
Results

Documentation

Test results provided velocity and

turbulence index factor maps of the center

fuel bundle obtained upstream and down-

stream of the first three spacer grids

and confirmed that the flow distribution

becomes uniform from the diffuser effects of spacer grids.

Test results indicated that the indivitual fuel bundle flow velocities at the botton of the fuel rods did not exceed $3 \%$ of average core flow velacity.

Th? evaluation concluded that $50 \mathrm{ft} / \mathrm{sec}$ was a conservative value after precicting maximum velocities as follows:
a. core regior $25.8 \mathrm{ft} / \mathrm{sec}$
b. upper plenum
c. upper plenum core flow 3.4 to 26.5
3.4 to
$\mathrm{ft} / \mathrm{sec}$
d. at $\rho v^{2}$ detector - center $11.4 \mathrm{ft} / \mathrm{sec}$ e. at $\rho v^{2}$ detector - corner $26.8 \mathrm{ft} / \mathrm{sec}$

ENC

University)

ENC

EVC

Columbia

Univarsity)
Test results confirmed that conventional bare-bundle interchannel thermal-mixing coefficiert correlations are appropriate for LOFT Fredictions.

The analysis predicted that the LOFT low flcw limitation was $2.77 \times 10^{6} \mathrm{lb} / \mathrm{hr}$ based on the $W-3$ correlation prediction and a mininum allo'wable DNB ratio of 1.30 .

Test results indicated that a trend existed in the subcooled region that departed (adversely) from the W-3 correlation orediction. Report": October 1974.
Exxon report, "XN-74-53, Analysis of the OFT Instrumented Fuel Assembly Flow Distribution Experiments", October 15, 1974, abstrac presented in "Water Reactor Safety Program - Experimental and Analytical Program Acisivities", Monthly Repart, December

Sombust: on Engineering report "CEND-369, LOFT Reactor Vessel =low Model Test Program Test

APR repart "MPR-509, Report of LOFT Fuel Jynamic Analyses", Volume III, Section B.l, March $1 \subseteq 76$.

Exxon report, "XN-74-40, Thermal Mixing

-n LOFT Fuel. Assemblies", Decenber 2, 1974. $\because$

Exxon rejort, "JN-72-14, Prel iminary ThermalFydrauli= Analysis for LOFT FuEl Assemblies", Apri1 24, 1972.

Exxon rezort, "NX-73-30, LOFT Fuel Departure =rom Nucleate Boiling Test Analysis and Results", December 1973. 
TABLE III (continued)

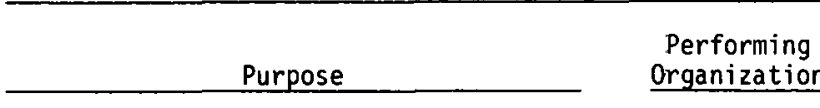

D. Departure from Nucleate Boiling (DNB) (continued)

\begin{abstract}
3. Additional DNB tes: data and evaluation to investigate and quantify adverse trend results of previous testing.
\end{abstract}

EG\&G
(Columbia
University)

E. Combined - Final prediction of LOFT fuei bundle thermal-hydraulic be-
havior based on evaluation of test program results.

\section{F. Conirol Rods}

1. Prediction of control ros poison temperatures and guide tube flow rates.

2. Prediction of control ros poison temperature during worst case planned LOCES to evaluate potential melting $\left(1425^{\circ} \mathrm{F}\right)$ of the $A G-I n-C d$ poison material.

G. Neutron Source - Prediction of heat generation and cooling requi rements.

ENC
Results

Documentation

Test data were obtained from 25 rod test bundles with and without thermocouple

simulation. The data evaluation indicated a DNB penalty (5 to $28 \%$ lower) caused by the LOFT fuel rod external thermocouple arrangement. A LOFT DNB correlation was developed which predicted a DNB ratio of 1.13 would satsify $95 \%$ confidence level safe operating criteria.

Analysis incomplete.

The analysis predicted that the worst case temperature of the poison material would be $803^{\circ} \mathrm{F}$ maximum and that the guide tube flow rate should not exceed $1.84 \%$ of the total fuel bundle flow rate at worst case (withdrawn control rod) conditions.

anc [a] The analysis which assumed both helium and argon fill gas conditions predicted that the melting temperature would not reach $1425^{\circ} \mathrm{F}$ until approximately $90 \mathrm{sec}$ after initiation of the pipe break which after initiation of the pipe break which perature above $2000^{\circ} \mathrm{F}$.

The analysis predicted an equivalent heat source of 0.008 watt which could raise the capsule temperature only $1^{\circ} \mathrm{F}$ assuming convection cooling of the outside guide tube surface only.
EG\&G report, TREE-NUREG- 1043, Evaluation and Results of LOFT Steady State Departure from Nucleate Boiling Tests, April 1977.

Exxon report, "JN-72-15, LOFT Contro Rod Cluster Design Report", July 18, 1972.

ANC LTR 1111-6, "LOFT Control Rod Poison Temperature History after a $100 \%$ Inlet LOCE with Delayed ECC Injection", June 27, 1972. and ANC letter report "Control Rod Poison Temperature History: Effect of Using Helium Instead of Argon in Control Rod Gas Space - HFR-5-72", July 11, 1972[a].

Exxon report, "XN-74-48, Design Report, LOFT Neutron Source Assembly", December 1974. 


\section{T.CBLE III (continued)}

\section{Purpose}

H. Fuel Module Thermal Expansi=n - Prediction of differential thermal growth between the fuel module and its end

supports during steady stat $\equiv$ and planned LOCE environments.

I. Fuel Bundle Irstrumentation Routing Prediction of guide tube instrumentation compionent temperatures during reactor operation.

[a] ANC is now EG\&G Idaho, In:.
Performing Organization

ANC [a]

Resuits

The analysis predicted a diffe-ential

tinermal expansion of 0.804 inc ? for fuel

mocules with stainless s.eel gride tubes

anc 0.252 inch with zircaloy gaide tubes.

EVC

The analysis predicted that the coolant

The analysi

flow through the instrumented guide tubes

satisfactorily maintains the iustrunent-

tation components at acceptable temper-

a :ure levels.
Documentation

ANC LTR 1111-7, "LOFT Fuel Assembly and Upper Support Structure Thermal Expansion Analys is" March 12, 1973[a].

ENC report, "JN-72-16, LOFT Instrumentation Routing Design Report", July 20, 1972. 
TABLE IV

LOFT FUEL MODULE STRUCTURAL DESIGN PROGRAM

Purpose

\section{A. General}

1. Preliminary prediction of fuel module axial loadings during representative expected LOCES assuming $1 \mathrm{msec}$ break time.

2. Prediction of LOFT fuel module axial loadings during representative expected LOCEs assumirg $1 \mathrm{msec}$ break time.

3. Latest prediction of LOFT fuel module axial loadings during representative expected LOCEs usirg an improved model and assiming both 1 -msec break of an $\varepsilon$-in. diameter pipe and 5 -msec brezk of a 5-in. diameter pipe.

4. -independent predic zion of LOFT fue: module axial loadings from Iten A. 2 data.

5. Prediction of LOFT fuel nodule axial loadings during earthquakes.
Performing Organization

ANC $^{[a]}$

ANC $^{[a]}$

$E G a ̊ a$

MPR

MPR
Results

Documentation

ANC LTR 1.1.1.3-1, "A Preliminary Dynamic Analysis of the LOFT Reactor Fuel Assemblies", January 28, 1971 [a].

ANC LTR 1115-25, "Dynamic Analysis of LOFT Reactor Flow Skirt-Core Filler Assembly for Nonnuclear and Nuclear Lossenvironment and a SHOCK code analysis using a lumped-mass-system response model resulted in a prediction of a worst case loading of 11,668 ib to a $15 \times 15$ size fuel bundle.

A WHAM code analysis of the hydraulic environment and a SHOCK cocie analysis using a lumped-mass-system response model resulted in prediction of a worst case loading to a $15 \times 15$ fuel worst case loading to a $15 x$ is fuel loduling 14,035 ib if comparison loading of $14,035 \mathrm{lb}$ if the energy absorption parameter is omitted in the WHAM hydraulic model. The slower (planned) break load was predicted to be $6248 \mathrm{lb}$ with the energy absorption parameter.

The evaluation predicted a worst case loading of $11,540 \mathrm{lb}$ to a $15 \times 15$ size fuel bundle.

The evaluation, using ANC ${ }^{[a]}$ generated reactor vessel seismic response spectra, predicted a vertical loading of $5.03 \mathrm{~g}$ compared to $4.15 \mathrm{~g}$ for bedrock response spectra and $10 \mathrm{~g}$ from subcooled blowdown loads.
EG\&G LTR 1111-31, "Dynamic Analys is of the LOFT Reactor Fuel Modules for Subcooled Blowdown Loads", December 21, 1976.

MPR report, "APR-509 Report of LOFT Fue Module Dynamic Analysis", Volume II, Section A.2, March 1976.

Same as above Volume II, Section A.3. 
TABLE IV (continued)

\begin{tabular}{c}
\hline$\cdot$ \\
Purpose \\
\hline
\end{tabular}

A. General (continued)

6. Prediction of -LOFT fuel module

lateral loadings during earthquakes.

7. Prediction of LOFi fue? bundle

guide tube and fuel rod locall forces and deflections when mid-spar: lateral deflection equals the availatile clearances.

8. Prediction of -OFT fue madule lateral loadings during $L=C E$.

9. Predicticn of LOFT fuel module axial loadirgs during reflood.

\section{B. Fuel Rods}

1. Predictian of fuel and sladding temperatures for use in oine

subsequent structural eva" dat"ons.
Performing

Organization

MPR

MPR

MPR

MPR

ENC .
Results

The evaluation, using ANC ${ }^{[a]}$ generated reactor vessel seismic response spectra, predicted a lateral loading of $6.7 \mathrm{~g}$ campared to $6.2 \mathrm{~g}$ for bedrock response spectra.

The evaiuation predicted worst case loadings as follows:

a. Fuel Rod

$\begin{array}{lr}\text { Shear load } & 1.7 \mathrm{lb} \\ \text { Axial load } & 5.7 \mathrm{ib} \\ \text { Bencing moment } & 12.6 \mathrm{in.}-1 \mathrm{~b}\end{array}$

Bencing moment 12.6 in. -1

b. Guice Tube Shear load $\quad 6.25 \mathrm{lb}$

Bencing noment 46.5 in $-1 \mathrm{~b}$

The evaulation predicted a lateral impact load of 922 lb assuming watermass damping of the core barrel motion (undamped loads were predicted to be $2090 \mathrm{lb}$ ).

The evaluation predicted an axial load of $6220 \mathrm{lb}$ at $1700^{\circ} \mathrm{F}$ guide tube tempera iure on the $15 \times 15$ fuel bundle $w^{-}$th stainless steel guide tubes and 3:00 10 at $1700^{\circ} \mathrm{F}$ guide tube temperature on the i5 $x 15$ fuel bundle with zircaloy guide tabes.

The anal/sis predicted a peak centerline fuel temperature of $4642^{\circ} \mathrm{F}$ assumir.g the linear heat generation rate of $19.0 \mathrm{~kW} / \mathrm{ft}$ and using the Lyons $\mathrm{UO}_{2}$ thermal conductivity correlation. The predicted maximum cladding temperature was $799^{\circ} \mathrm{F}$ at $19 \mathrm{~kW} / \mathrm{ft}$

\section{Documentation}

Same as above Volume II, Section A.4.

Same as above Volume II, Section A.5.

MPR report, "MPR-509, Report of the LOFT Fuel Module Dynamic Analysis", Volume II Section A.6, Appendix A, March 1976.

Same as above Volume II, Section A.7.

Exxon reports:

a. "JN-72-4, Standard LOFT Fuel Rod

Design Report", March 2, 1972.

b. "JN-72-5, Standard LOFT Fuel Rod Design Report Addendum 1", March 17, 1972. 


\section{TABLE IV (continued)}

Purpose

\section{B. Fuel Rods (continued;}

2. Prediction of cladding strains to corfirm that strain imitations of $1 \%$ are: not exceeded.

3. Prediction of fission gas release and resulting internal fuei rod pressure for use in subsequent structural evaluations.

\section{Analys is of fuel rod cladding} stresses to predict

. Instantaneous col apse pressure

b. Time to sreep coliapse

\section{c. Primary stresses}

d. Thermal-inechanica' effects (mechanical bending, thermal bowing, temperature gradient and flow-induced vibrations)

e. Axial loads from iuel bundle skeleton differential thermal expansion.

5. Prediction of pellet stack holddown spring force requirenent and spring characteristics.

6. Prediction of potential fuel densification effects oi fuel rod behavior. a. Pellet stack gap size and frequency
Performing

Organization

The analysis, which inclucied consider

ation of fuel swelling, thermal condi-

tions, and power history, indicated the

design satisfied the $1 \%$ strain limitation.

The analysis, which included temperaturezoned release of all or portions of the

volatile $\mathrm{UO}_{2}$ impurities and gaseous fis-

sion products to the fuel rod void volume, predicted a total EOL gas pressure of

2500 psi assuming a commercial PWR life-

time requirement of 30,000 MWd/MTU.

The analysis predicted the following:

a. An instantaneous collapse pressur

b. Time to creep collapse of approximately. 1800 hours.

c. Primary stresses slightly exceeding $1 / 3$

of the minimum specified ultimate strengt

d. (Results included in $c$ )

e. A total force of 24 lb (stress results included in $\mathrm{C}$ )

The analysis results determined, the geometrical requirements for an Inconel $X-750$ spring that would provide a nominal $4 \mathrm{~g}$ spring force.

The analysis which used the November 14 , 1972, USAEC fuel densification guidel ines 1972, USAEC

a. Cladding collapse could occur in 1050 hours
Documentation

Same as above.

Same as above.

Same as above (Item a).

Same as above.

Exxon report, "XN-73-28, LOFT Fuel Densification Study", October 22, 1973. 


\section{TABLE IV (continued)}

Purpose

Performirig
Organization

\section{B. Fuel Rods (continued)}
b. Cladding stresses
c. Creation of power spikes
d. Fuel centerline temperature
e. DNB behevior.

7. Analytical evaluation of fuel rod cladding stresses during worst case expected LCCES.

8. Prediction of stresses in the fise rod claddirg at spacer grid contact locations curing worst case _OCE a רd earthquake.

9. Prediction of fuel rod st ^esses under Item E.12 (towed guide tube) conditions.

\section{Control Rods}

1. Prediction af tuffer spring assembly characteristics required to absorb. the terminal kinetic energy of the cortrol rod cluster assembly.

2. Prediction of buffer soring stresses during absorption $0^{-}$ control rod cluster assenoly kinetic energy.

3. Prediction of spider àrm stresses during scran deceleration b. Centerliae fuel tenperature les; than melting at $19 \mathrm{~kW} / \mathrm{ft}$

c. Precautions are necessary to freserve the 1.30 DNB margin.

MPR

The evaluation predicted a $22 \%$ s-ress intensity increase during the LOCE and concluded primary stresses would be less than yield stresses as long as the cold worked material properties are maintained.

The evaluation predicted worst case load fuel cladding stress of 41,280 psi compared to 60,000 psi allowable.

The evaluation predicted no adverse (a) Thechanizal effects or (b) thermai effects based on FLECHT simulated flow biockage test results.

The analysis predicted stresses approximately $5 \%$ below allowable stresses.

The analysis determined that: two concentric Incone $1 \times-750$ springs would achieve the Jes.ign' Jbjective.
The analysis predicted stresses, approximately $10 \%$ bel.ow al.lowable stresises.
MPR report, "MPR-509, Report of LOFT Fue Module Dynamic Analysis", Volume II, Section B.4, March 1976.

MPR report, "PIPR-509, Report of LOFT Fue Module Dynamic Analysis", Volume III, Section C.6, March 1976.

MPR report, "Addendum No. 2 to MPR-509, Report of LOFT Fuel Modules Dynamic Analysis", Appendix B, Attachment 1 . December 1976.

Exxon report, "JN-72-15, LOFT Control Ro Cluster Design Report", July 18, 1972.

Same as above.

Same as above. 


\section{TABLE IV (continued)}

\section{Purpose}

c. Control Rods (continued)

\section{Prediction of control rod} elastic behavior under worst case misalignment conditions.

5. Prediction of control rod ciadding stresses and collapse characteristics.

6. Prediction of control rod vibration characteristics.

7. Prediction of control rod drop time to provide information for designing buffer springs and spider webs.

8. Experimental determination of control rod cluster drop time and confirmation of control rod cluster structural capabilities.
Performing

Organization

ENC

ENC

MPR

$\mathrm{ANC}^{[\mathrm{a}]}$ \&

ENC

ENC
Results

The analysis predicted the control

rods to be flexible and accommodating to

potential worst case misalignment conditions.

The analysis predicted that cladding stresses from external pressure, thermal gradients, and potential mechanical bending to be less than allowables. The internal $3140 / 2775$ psi at RT and $650^{\circ} \mathrm{F}$.

This analysis which included as-built material and dimensional characteristics and more accurate analytical techniques predicted internal collapse pressures to be $3989 / 3711 \mathrm{psi}$ at RT and $650^{\circ} \mathrm{F}$.

The analysis concluded that the control rod vibration within the guide tube would not be a problem.

The analysis predicted the control rod drop times to be $0.97 \mathrm{sec}$ for $75 \%$ insertion full insertion from full

thdrawal at reactor operating conditions.

The experimental data confirmed the LOFT and indicated 0.75 and $2.0 \mathrm{sec}$ to 75 and $100 \%$ insertion under expected alignment conditions, 0.95 and $2.15 \mathrm{sec}$ to 75 and $100 \%$ insertion under siaulated worst case misalignment conditions, and terminal velocity of $5.2 \mathrm{ft} / \mathrm{sec}$.
ANC LTR-1111-16, "LOFT Control Rod

Collapse Prediction", February 25, $1975^{[\mathrm{a}]}$

Exxon report, "JN-72-20, LOFT Fuel Design Report - Addenda", September 18, 1972.

ANC internal letter BVW-4-71, "LOET Scram Time Analysis", August 20, 1971[a]. ENC report (see C.i).

ENC report; "XN-74-57, LOFT. Reactor Control Cluster Insertion Tests", December 1974. 


\section{TABLE IV. (continued)}

\section{Purpose}

9. Prediction of mechanical laads and thermal conditions during LOCE and seismic events.

10. Prediction of stress under Iteni C.9 loading conditions for the

following coktrol rod compenents:

a. Spider

b. Control rad ciaddirg ens

fittings, absorber rod, an= spring

c. Shafts

e. Spring retaining bolt fastening.

11. Prediction of control cod stresses under Item E.12 (bowed gui.je tabe) conditions.

\section{Spacer Grids}

1. Establish spacer grid saring geometry to "force a node" when the fuel rod is vibrating, elastically accommedate manufacturing tolerances ard imposed assenbly ceflection, accommodate fuel rod diametral changes and prevent Jamage to the fuel rod cladding.

2. Predict stresses in spacer grid springs and welds cue to expecied vertical loads.

Performing

Organization

MPR

\section{Documentation}

MPR report, "IAPR-509, Report of LOFT Fuel Module Jynamic Analysis", Volume III, The eva
follows:

a. Vertical load $6.8 \mathrm{~g}$ (seismic event) Section A.1, March 1976.

c. Peak poison $6.7 \mathrm{~g}$ (seismic event)

$$
\text { temperature }
$$

Same as above Volume III Sections A.2 ditions below the allowable stresses. through A.6.
A combines analytical and experimental program was employed. The analytical program was based on a beam model and the experimental program consisted of deadweight loading a single spacer grid cell mo:kip. A spring configuration was developed that satisfied the design requirements.

The evaluation predicted no adverse the evaluation predic predicted the maximum stresses to

c.c sur at the intersection welds anc that the ncimum stresses would not exceed al lowable stresses.
MPR report, "Addendum 2 to MPR-509, Report of LOFT Fuel Modules Dynamic Analysis," B, Attachment 1, December 1976

Exxon report, "JN-72-9, LOFT Fuel Rod Irid Spacers, Design Report", Apri1 24, ing72.

jame as above. 


\section{TABLE IV (continued)}

Purpose

D. Spacer Grids (continued)

\section{Predict stresses in strip due to} possible unbalanced spring-todimple load.

4. Evaluate combined effects of vertical and unbalanced loads.

5. Predict the faticue betavior of the springs.
Performing

Organization

ENC

(n)

6. Determine the spacer grid weight.

7. Evaluation of spacer grid response to loadings during iuel loading (fuel assembly lower tie slate vertical velocity of $40 \mathrm{i}$. $/ \mathrm{min}$ ).

8. Evaluation of spzcer grid response to a lateral 6-g load a lis seismic load.

9. Experimental determination of intersection joint strength.

ENC

ENC
Results

Documentation.

Same as above.

A linear elastic analysis using a shell

model predicted a maximum stress intensity

al lowable yield stress of 150,000 psi.

The analytical evaluation predicted a maximum combined stress intensity of

101,200 psi.

The analytical evaluation predicted the fatigue life, based on an alternating

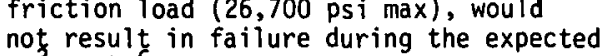
not result in failure during the expect
$10^{3}$ to $10^{6}$ number of cycles since the alternating stress limit for $10^{6}$ cycles is 110,000 psi.

The analysis predicted the weight to be 860 grams for the $15 \times 15$ spacer. Actual measured weights are 848.3 and $363.8 \mathrm{~g}$

for the $15 \times 15$ and corner spacer, respectively.

The analysis, which used a beam model and the STRESS-II code, predicted that in the abrupt stop situation the spacer strips, abrupt stop situation the under direct loadin but not fracture at the strips or in section joints.

The analysis predicted maximum stress in the strips of 55,000 psi (approximately $80 \%$ of the allowable load).
The experimental results indicated a strength of 387 ib in tension compared to a $141 \mathrm{~b}$ design requirement and $11351 \mathrm{~b}$ in shear.
Same as above.

Same as above.

Same as above (analysis only)

Exxon report, "JN-72-20, LOFT Fuel Design Report - Addenda", September 18, 1972.

Same as above.

Exxon report, "XN-104, Report of Experimental Determination of LOFT Grid Spacer Strength", February 1973. 


\section{TABLE IV (continued)}

\section{Purpose}

\section{Spacer Grids (continued)}

10. Experime.tal determinazior. of $s^{-d e}$ plate weld strength to evaluate shear resistance characteristics during the fuel loading ccndition of Item 7 above.

11. Experimental determination of spacer grid response to the fuel

loading condition of Item -.

12. Experimental confirmation tha: the spacer grid design damisens fuel rod vibration and prevents damage by the fretting corrosion prozess.

13. Predicticin of LOFT spacer grid lateral impact loads during LOSE and earthquake events.

14. Test of LOFT spacer grif lateral impact load capacity.

15. Prediction of moments and shear forces applied to spacer grid during fuel assembly lateral defle:tion.

16. Prediction of stresses in the spacer grid structure durirg werst case LOCE and seismic loads.
Performing

Orgenization

ENC

The experimental results indicated a

weld joint bending moment capability of

dicted load of 0.2 in.-lb.

ENC

The experimental results indicated the spacer grid would not fail catastrophisally (fracture) up to ioads of 4000 lb campared to the Item 7 loading condition of $35001 \mathrm{~b}$.

The experiments, which included 1500-hour flow environment test of full-size $15 x$ 15 and corner instrumented fuel bundle prototypes, demonstrated that the design was satisfactory.

the evaluation predictec worst case load ings or inpact velocities as follows:

a. LOCE $1.2 .1 \mathrm{in} . / \mathrm{sec}$

b. Earthquake $3630 \mathrm{lb}$.

ENC \& Westinghouse

The testing indicated the spacer grids could absiorb, without permanent distortion, the following lateral. impact loads:

$$
\begin{array}{ll}
\text { Westinghouse Test } & 4400 \mathrm{lb} \\
\text { Exxon Test } & 3600 \mathrm{lb} .
\end{array}
$$

The evaluation predicted worst case raments $0=4.4$ in. $-1 \mathrm{~b}$ and shear forces cf 1.31 lb at each fuel rod location.

The evaluation concluded that (a) the

spacer $g^{-} d s$ should be capable of withstanding LOCE subcooled blowdown vertical loads, ib: spacer strip and intersection welds (fuel rod locations) stresses do not exceec allowables during lateral fuel

\section{Documentation}

Same as above.

Same as above.

Exxon report, "XN-74-61, LOFT Frettin Corrosion Test Report", December 30, 1974

MPR report, "MPR-509, Report of LOFT Fuel Module Dynamic Analys is", Volume II Section A.6, March 1976.

Same as above.

Same as above volume II, Section B.3, Appendis $A$.

Same as above Volume II, Section B.3. 


\section{TABLE IV (continued)}

\section{Purpose}

D. Spacer Grids (contiาued)

17. Prediction of stresses in spacer grid springs and dimples during worst. case LOCE and earthquake.

\section{E. Skeleton}

1. Preliminary prediction of guide

LDFT fuel technical specifications.
Performing

Organization

2. Prediction of guide tube structural response to expected axial loads (maximum) of 5490 lb (for $15 \times 15$ bundle) at room temperature.

3. Prediction of stresses in the upper and lower tie plates.

4. Prediction of guide tube mechanical
Results

Documentation

assembly deflection (see Item A.7), (c) spacer strip intersection welds at guide tube locations exceed allowables, and (d) fatigue tests of the intersection weld joint should be run.

The evaluation concluded that neither LOCE or earthquake would result in adverse effects to the spacer grids.

The analysis, which considered the combined effects of bending and column instability, predicted the required guide tube wall thicknesses of $0.038 \mathrm{in}$. for 304 SS and 0.100 in. for $2 r-4$ compared to a desired 0.015 in.

This analysis predicted that the LOFT guide tube wall thickness should be 0.017 in. to satisfy the revised (com0.017 in. to satisfy the revised (comspecifications.

This analysis, which used a beam element analys is program, predicted the expected axial loading conditions would result in a maximum tie plate stress of 9000 ps compared to the allowable level of 14,000 psi. attachments stresses.
This analysis, which considered the attachment of the guide tube to sleeve, the guide tube to lower end cap, and upper sleeve to nut fastening system, indicated the attachments were capable of withstanding axial loads of $2000 \mathrm{lb}$.
Same as above Volume III, Section C.6.

Exxon report, "JN-72-7, LOFT Fuel Supply Guide Tube Strength", April 4, 1972.

Exxon report, "JN-72-10, LOFT Fuel Assembly Structural Design and Analysis", May 8, 1972.

Same as above.

Same as above for 304 SS. For $2 r-4$ see Exxan reports, "XN-74-47, LOFT Type F Fuel Assembly Structural Design and Analyses", December 1974 and "XN-74-41 Revision 1. LOFT Type F Fuel Assembly. Structural Design and Analysis", July 1976. 
TABLE IV (continued)

\section{Purpose}

\section{E. Skeleton (coritinued)}

5. Determination of guide tube to spacer grid locking ring

attachment (4 spot welds $p \equiv r$ ring) strength.

6. Experimental determination of fuel bundle strencth characteristics including sefarate determi iations of tie plate and empty skeleton characteristics and fuel bundle response to worst case misalign-

7. Experimental cetermination of LOFI guide tubes mechanical proxertíes in compressicn at high temperatures $\left(1000,1300\right.$, and $\left.1500^{\circ} \mathrm{F}\right)$ for use in evaluating LCFT fuel bundle re sponse durinc LOCEs.

8. Prediction of guide tube and end box maximum expected temperatures curing LOCE.

9. Prediction of stress under worst case LOCE and seismic loads (see Items A.4 through A..9) for the following fuel buncile skeleton components:

a. SS guide tubes
b. Zircaloy guide tubes

c. Upper end box

d. Lower end box

e. Instrumentation tub

Performing

Organization

ENC

The experimental results indicated the axial load capabilities to be 16201 for the 304 SS and 1170 ib for the $7 r-4$ compared to a design load of $200 \mathrm{lb}$.

ENC

The experimental results indicated: a. Tie plate (upper) yield stresses at 10,000 lb axial load

b. Guide tube-spacer grid (skeleton) load capabilities of $22,0007 \mathrm{~b}$

c. No significant deterioration of axial strength in the misaligned condition d. A fuel bundle naturai frequency $0^{-}$ 320 Hertz.

ENC

The experimental results indicate nechanical properties in compression at these ical properties in compression at these SS and $10 \%$ for $\mathrm{Zr}-4$ ) than published tensile mechanical properties data.

The evaluation concluded that the following maximum temperatures should be used for subsequent evaluations:
a. Guide tubes
$1700^{\circ} \mathrm{F}$
b. Upper end box
$1000^{\circ} \mathrm{F}$
c. Lower end box

$700^{\circ} \mathrm{F}$

MPR

The evaluation concluded that the following additional work should be accomplished:

a. Modification of several Type $F$ fastener connections

b. Fatigue life testing of the spacer grid intersection welds and tie-plate-to-upper intersection welds and tie-plate-to-upper

c. Elevated temperature load testirig of the

d. Reprediction of subccioled blowdcwn loads
Documentation

Exxon report, "XN-104, Report of Experimental Jetermination of LOFT Grid Spacer Strengt $7 "$, February 1973.

Exxon report, "xi்-74-28, LOFT Fuei Assembly Strength Test, Test Report", July 15, 1974.

Exxon report, "XN-74-50, Guide Tube Compression Tests - Test Report", November 1974.

MPR report "MPR-509, Report of LOFT Fue Module Dynamic Analyses", Volume III, section A.7, March 1976.

jame as above Volume I, Appendix $B$, and Jolume :I, Section II.B. 


\section{TABLE IV (continued)}

\section{Purpose}

\section{E. Skeleton (continued)}

f. Upper end box to tie plate connection

g. SS guide tube to tie plate connections

h. Zircaloy guide tube to tie

piate connections

i. Guide tube to spacer grid

connection

connection

$j$. Instrumentation tube to

lower tie plate connection

ti In plate connection

10. Reprediction of stress under worst case LOCE loads (see Item A.3, Appendix A) for the upper tie pliate to end box connection.

11. Additional prediction of guide tube thermal conditions and axial mechanical loads during worst case LOCE.

12. Prediction of stresses in stainless steel guide tutes considering the radial temperature gradients

predicted in Item E.Il.
Performing

Organization

Results

Documentation

. More accurate prediction of guide tube temperatures during LOCE.
The evaluation predicted that the dowel pin bearing stress was 18,600 psi compared to 15,200 psi allowable and 48,270 predicted in Item E.9.

The evaluation, which considered results from FLECHT and Semiscale tests, predicted the following:

a. Peak guide tube temperature

temperature

$1540^{\circ} \mathrm{F}$

c. Maximum rad

$1110^{\circ} \mathrm{F}$

c. Maximum radial guide tube

temperature variance from

temperature dur

blowdown

d. Maximum radial guide tube temperature variation in fuel

bundle during reflood

$1700^{\circ} \mathrm{F}$ guide tube temperature

$750^{\circ} \mathrm{F}$

$311 \mathrm{lb}$

The evaluation predicted bowing of the guide tubes contact, with fuel rods externally and control rods internally average bundle guide tube
Same as above Volume II, Section A.6, Appen$\operatorname{dix} A$.

MPR report, "Addendum 2 to MPR-509, Report of LOFT Fuel Module Dynamic Analysis", Appendix A, December 1976.

Same as above A.ppendix. $B$ 


\section{TABLE IV (continued)}

\section{Purpose}

E. Skeleton (continued)

13. Prediction of stresses in zircaloy cuide tubes considering the radial temperature gradients pred $^{-}=$ted in Item E.11.

\section{F. Neutron Source}

1. Prediction of hclddown spring assembly. characteristics required to provide a $65-1 \mathrm{~b}$ force of engagement.

2. Experimental corfirmation $0=$ design configuration durirg exposure =0 expected reactor oferating condition.:

\section{G. Upper Support Structure}
1. Prediction of LQIFT fuel nodule tupper structure axial loads during rorma T, LOCE, and LOCA conditions. The LOCE loads were prediciad assuming an instantaneous breat of an 8 in. Schedule $150 \mathrm{p}^{\circ}$ pe close to the reactor vessel. The $-O C A$ loads were predicted assum in an instantaneous break of an $1^{*}-$ in. ID pipe in the reactor vesse cutlet nozzle.

\section{Performing}

Organization

Results

(a) stresses within allowable values and (b) mechanicai load carrying capacities.

The evaluation predicted the guide tubes have sufficient strength to withstand the resulting axial loads up to about $1500^{\circ} \mathrm{F}$ and recomnended additional experimental investiga:ion of the guide tube buckling characteristics at elevated temperature.

The analysis determined that two concentric Inconel $X-750$ springs would ach"eve the design objective.

The experiment, which included a 1500hour flow environment test of a pretotype neutron source rod assembly demonstrated that the design was sat"sfactory.

The analysis predicted the following axial loads:

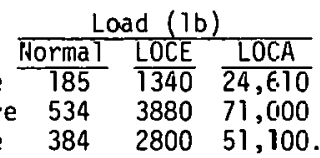

Same as above Appendix $\mathrm{C}$.

Documentation

Exxan report, "XN-74-48, Design Report LOFT Neutron Source Assembly", December i 974 .

Exxan report, "XN-74-61, LOFT Fretting Corrosion Test Report", December 30, 1974.

MPR report, "MPR-316, Design Report for LaFT Fuel Assembly Upper Support Structures", November 1971. 


\section{TABLE IV (continued)}

G. Upper Support Structure (continued)

2. Prediction of corner structure stress and fatigue conditions under normal, LOCE, and LOCA comditions for the following conponents:

a. Ma in support tube

a. Ma in support tube
b. Lower and intermediate support

pads

c. Core plate pins

d. Holddown spring

e. Spring deflector.

3. Prediction of center structure stress and fatigue condition under

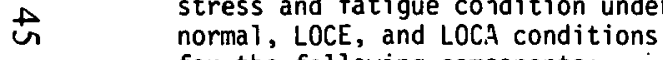

for the following comjonents:

a. Main support box structure

b. Ma in support corner bars (at

reactor vessel nozzle level)

c. Instrument channel

d. Lower, intermediate, and upper

support pads

e. Holddown spring

f. Adjusting nut

g. Orifice plate.

4. Prediction of contmol guide structure stress and fatigue conditions under normal, LOCE, and LOCA conditions for

the following componeits:

a. Drive shaft shroud

b. Control rod guide tubes

c. Alignment pads

d. Alignment pins.
MPR
MPR

PR

The analysis predicted that all structure components analyzed would have (a) stress conditions below the allowable stresses and in most cases substantially below (factor of 10) allowables, and (b) no

cumulative fatigue usage factor.

Same as above except I tem 4 (lower support pads) and Item 7 are reported in MPR letter report, "Analysis of Center Fuel Module

Orifice Modification", June 10, 1974.
Same as above.

\section{Documentation}

Same as G.1. 


\section{TABLE IV (continued)}

\section{Purpose}

G. Upper Support Structure (continued)

5. Prediction of control structure stress and atigue conditions under normal, LOCE, and LOCA CONditions for the following components:

a. Main support box structure b. Main support corner bars (at reactor vessel nozzle level)

c. Instrument channel

d. Lower and intermediate support pads pads
Performing

MPR

Same as abcre.
Orcanization

6. Preliminary prediction of therma stresses during $L O C E$ reflcoding (bottom injection) or deluging (top injection).

7. Additional prediction of effect of LOCE top ejection on upper support structures.
8. Prediction of natural irequency
for the fol:owing:
a. Control upper structures
b. Center upper structures
c. Corner upper siructures
e. Control rod guide struzture
9. Preliminary prediction of holddown spring design characteristics. This
analysis included prediction of the holddown force requir=ments.

Results

Results

\section{Documentation}

Same as above.
MPR

The analysis predicted that (a) stress

levels nould be acceptable during re

rloodinc, (b) stress levels during

seluginc could limit the number of cycles

to 37 , and (c) additional analysis should tie perfcrmed.

This analysis predicted that unsatisfactory cistortion could occur during top ejection.

MPR
The arialysis predicted the following ratural frequencies:

ratural frequencies: 270 to 2380 cps control structure - 270 to 2380 CPs center structure - 270 to $2330 \mathrm{cps}$ Shroud - 360 cps

Euide structure - 510 to $4100 \mathrm{cps}$.

The analysis preficted the holddown springs should provide a holddown force of $6500 \mathrm{lb}$ for $15 \times 15$ fuel modules and allow up to $0.70-i n c h$ differential crowth of the fuel module.
Sáme as above.

MPR letter report, "Effects of Upper Upper support Structures", May 10, 1973.

Same as G.1.

Same as above. 


\section{TABLE IV (continued)}

\section{Purpose}

G. Upper Support Structure (continued)

10. Additional prediction of holddown spring characteristics to provide

a holddown force of 1000 . $1 \mathrm{~b}$ for

$15 \times 15$ fuel modules and $500 \mathrm{lb}$ for

corner fuel modules and spring rate

of $2000 \mathrm{lb} / \mathrm{in}$.

11. Additional prediction of holddown spring characteristics to provide a

spring constant of $5 \mathrm{E} / \mathrm{b} / \mathrm{in}$.

12. Additional prediction of holddown spring characteristics to correct the differential growth requirement to 1.07 in. (ceriter bundle) and $1.02 \mathrm{in}$. for corrier and contro bundles.

13. Final prediction of holddown spring characteristics to correct a $\pi$ isunderstanding regarding the definition of "installed length" definition of "installed length" which had resulted in a higher

\section{H. Instrumentation Penetration}

1. Prediction of stresses during normal operating conditions for the following (5-in.-diameter perietration) pressure boundary components

a. Head bolts

b. Pressure tube

c. Pressure plate

d. Braze buttons.
Performing

Organization

Results

MPR

This analyses predicted a set of spring geometries to meet the specified re-

quirements. In addition, evaluations

were made of fuel bundle loading during

LOCE subcooled blowdown and core heatup phases and predictions of improved fuel bundle guide tube characteristics.

MBR

This analysis resulted in a recommendation to correct the holddown spring constant to $500 \mathrm{lb} / \mathrm{in}$. and predicted a sat of spring parameters that satisfied the of spring parameters that satisfied the
revised spring constant requirement.

AnC [a] The analysis predicted a set of spring arameters that satisfied. the requirement for holddown force and spring constant

Adic [a] This analysis resulted in the establishment of a set of spring design parameters that finally satisfied the recuirement for holddown force, spring rate and differential growth.

$\mathrm{AHC}^{[\mathrm{a}]}$

The analysis predicted that the design for all configuration analyzed was adequate (within ASME Section III, Class allowables) for the design conditions

with one exception, which was corrected

by increasing the quantity of heat bolts.

\section{Documentation}

MPR letter report, "Al ternate Holddown Spring Designs for LOFT Fuel Modules", August 22,1972 .

MPR letter report, "Spring Constant for Fuel Module Holddown Springs", August 29, 1972.

ANC letter report, "LOFT Reactor Fuel Assembly Holddown Springs-Saff-22-72", October 12, 1972 and "Type F Fuel Module Holddown Spring-Saff-26-72", November 27 1972 [a].

Unpuplished ANC analysis dated May 21, 1973[a].

ANC letter report, "LOFT Instrumentation Center Penetration, 5 in. - Fors-3-73", Apri1 4, 1973[a]. 


\section{TABLE IV (continued)}

Performing

Orgaization

\section{Purpose}

H. Instrumentation Penetratior (continuzd)

2. Predictior of stresses turing normal operating condition: for inconel-titarium upper and lower inconel-titarium upper and low buttons, 304 SS lower buttimn the follcwing weld designs: a. Pressure tube weld

b. Teleflux tube we

c. Connector weld

d. Lead seal weld

$\epsilon$. Mounting sleeve weld

f. Standoff weld.

expected loads for the following fivot arm components:

a. Lower pivat pin

b. Upper pivat pin

c. Support bracket (part $0=$

upper structure)

d. Arm (shoulder area).

4. Experimental determinat- on of titanium-tantalum-Inconel explosionbonded sandwich (Detaclad)

material mechanical character-

istics under the fcllowing zonditions:

a. Simple tensile laading:

b. Ram tensile loading

c. Braze cycling

d. Bending loading

e. Thermal cycling ( 100 cycles

135 to $650^{\circ} \mathrm{F}$ )

f. Stress-corrosion (1300 psi stress levels for 3000 hour; in $2500 \mathrm{psi}, 600^{\circ} \mathrm{F}$ borated water simulating LOFT coolant chenistry conditions.

AvC [a] The analysis predicted that the design, -or all configurations analyzed, wes adequate (within ASME Section III, Class - allowables) for the design conditions allowabiles) for the design conditions by increasing the lead seal weld leg to ay incea used a finite element model of the button.

The analysis predicted the design, for all configurations analyzed, was adequet

Iwithin A.JME Section III, Class I allow-

cbles) for vertical loadings up to $500 \mathrm{lb}$. Module Pivgt Arm Assembly - BVW-4-73", May 23, 1973[a].

ANC letter report, "Analysis of LOFT Instrumentation Penetrations - BVW-5-73",

Juljig 9, 1973[a].
The experiments indicated that the Detaclad mate-ial has (a) adequate loac-

cerrying capability for the LOFT service conditions, (b) satisfactory corrosion resistance, and (c) satisfactory dimensional and nechanical properties stability inder both brazing and normal operation thermal c: c ing.
ANC letter report, "Transmittal of Test Results Detaclad Composite Material, 


\section{TABLE IV (continued)}

\section{Purpose}

Organization

H. Instrumentation Pene-ration (continued)

\section{Experimental determination of the} center fuel bundle instrumentation penetration assembly response to four 500-hour cycles of exposure to

2500 psi, $600^{\circ} \mathrm{F}$ borated water

(simulating LOFT coolant cinemistry

condition) terminated by a blowdown

plus a preliminary hydrostatic test plus a prelimina
at 3125 psig.

\section{Prediction of strasses under worst} case LOCE and seismiz loads for the instrumentation penetration pressure

$\mathrm{AvC}^{[\mathrm{a}]}$

\section{Fuel Bundle Instrumentation Attachment}

1. Prediction of stresses in instrumented fuel rod-to-upper-tie-plate fastener arrangement.

\section{Prediction of stresses and} fatigue life in the coolant thermocouple hot-junction protrusion $(0.125$ in.) into the tie plate flow channel.

3. Prediction of stresses in the instrument cable unsupported spans including the guide tube instrumentation assembiy instrument cable coils.

The experimental results indicated satisfactory performance of the instrumentation assembiy.

The evaluation concluded that the pressure tube will not be adversely affected during LOCE or earthquakes.

The analysis predicted that allowable strength limitations would not be exceeded at an instrumented fuel rod cap screw torque of 8 in.-1b at ambient conditions.

The analysis predicted that the design configuration would withstand both normal operating and the specified LOCE design conditions.

The analysis, which included evaluation of flow-induced vibration, predicted that the design configuration was adequate (a) for a 300-psi transverse differential pressure except for the fuel rod themocouples where transverse loads of this magnitude were judged to be unappropriate, and (b) the specified temperature conditions.

\section{Documentation}

\section{Not available.}

MPR report, "MPR-509, Report of LOFT Fue Module Dynamic Analysis", Volume III, Section A.1, March 1976.

Exxon report, "JN-72-20, LOFT Fuel Design Report Addenda", September 13, 1972.

Exxon report, "JN-72-16, LOFT Instrumentation Routing Design Report", July 10 , 1972.

Same as above. 
TABLE IV.:(continued)

\begin{tabular}{|c|c|c|c|}
\hline ?urpose & $\begin{array}{l}\text { Performing } \\
\text { Organization } \\
\end{array}$ & Results & Documentation \\
\hline \multicolumn{4}{|l|}{ I. Fuel Bundle Instrumentation Attachment } \\
\hline $\begin{array}{l}\text { 4. Prediction of stresses in the } \\
\text { instrument cajle bundle tiejowns } \\
\text { (staples). }\end{array}$ & ENC & $\begin{array}{l}\text { The analysis predicted that the design } \\
\text { configura-ion could. Withstand the } 30 C_{-. p s i} \\
\text { trarisverse differential pressure. }\end{array}$ & $\begin{array}{l}\text { jane as above. } \\
\end{array}$ \\
\hline $\begin{array}{l}\text { 5. Prediction of stresses in the } \\
\text { liquid-level routing fixtur:. }\end{array}$ & ENC & $\begin{array}{l}\text { The analysis predicted that the design } \\
\text { configuration would withstand the 30G-psi } \\
\text { trarsverse differential pressure. }\end{array}$ & Jane as above. \\
\hline $\begin{array}{l}\text { 6. Experimental confirmatian of fuel } \\
\text { bundle instrunent attachmerit designs } \\
\text { to withstand expected normel reactor } \\
\text { flow conditions. }\end{array}$ & ENC & $\begin{array}{l}\text { The experiment consisted of } 1500 \text {-hour } \\
\text { flow environnent tests of a full-size } \\
\text { frototype and demonstrated that the design } \\
\text { was satis=actory for expected normal } \\
\text { reactor f ow conditions. }\end{array}$ & $\begin{array}{l}\text { Exxon rEports, "XN-74-61, LOFT Fretting } \\
\text { Corrosicn Test Report", December } 30,1974 \text {, } \\
\text { and "XN-75-12, LOFT Fretting Corrosion } \\
\text { iest ReFort, Addendum 1, Instrumentation } \\
\text { Examination Results", March } 1975 .\end{array}$ \\
\hline $\begin{array}{l}\text { 7. Experimental confirmation of fuel } \\
\text { rod thermocouple attachment response } \\
\text { to a series of temperature syciing } \\
\text { programs representing reactior con- } \\
\text { ditions as follows: } \\
\text { a. Cycle program consisting of } 1 \\
\text { cycle, } 400 \text { to } 1100^{\circ} \mathrm{F} \text {; } 5 \text { cycles, } \\
400 \text { to } 1500^{\circ} \mathrm{F} \text {; and } 5 \text { cycles, } 400 \\
\text { to } 1700^{\circ} \mathrm{F} \\
\text { b. Cycle program consisting of } \\
20 \text { cycles, } 40 \mathrm{~J} \text { to } 745^{\circ} \mathrm{F} \text {; aris } 1.5 \text { cycles, } \\
400 \text { to } 1400^{\circ} \mathrm{F} \text {. }\end{array}$ & ENC & $\begin{array}{l}\text { The exper: ment results indicated that } \\
\text { improvements could be made in the weld } \\
\text { design since some weld failures occurred } \\
\text { during testing. }\end{array}$ & $\begin{array}{l}\text { "xxon report, "XN-74-62, LOFT Instrumented } \\
\text { =uel Roc and Guide Tube Thermal Cycling and } \\
\text { Corrosicn Test", December 31, 1974. }\end{array}$ \\
\hline $\begin{array}{l}\text { 8. Experimental confirmation of guide } \\
\text { tube instrumentation assemt.ly } 14 \\
\text { guide tube } T / 2 \text { models) resfonse to } \\
\text { a temperature cycling program } 120 \\
\text { cycles, } 400 \text { to } 675^{\circ} \mathrm{F} \text {; and } 15 \text { cycles, } \\
400 \text { to } 1400^{\circ} \mathrm{F} \text { ) representing normal } \\
\text { reactor operating and LOCE sonditions. }\end{array}$ & ENC & $\begin{array}{l}\text { The exper ment results indicate that the } \\
\text { design is satisfactory. }\end{array}$ & Jane as above. \\
\hline
\end{tabular}




\section{TABLE IV (continued)}

\section{Purpose}

\section{Performing}

Grganization I. Fue Bundle Instrumentation Attachment

9. Experimental confirmation of fuel rod thermocouple attachment response to a combination thermal and hydraulic loading cyclic program representing expected LOCE conditions as follows: a. $d$ three-cycle test consisting of heating to 1400,1600 , and $190 J^{\circ} \mathrm{F}$. $\mathrm{cladd}$ ing temperature and blowing dowr (4-joule weld characteristics)

b. A nine-cycle test consisting b. A nine-cycle test consisting of neating to $1300^{\circ} \mathrm{F}$ (1 cycle) $1400 \mathrm{~F}$ (5 cjcles), $1600 \mathrm{c}$ (6.5-joule weld characteristics) Test specimens include full-length samples.

10. Experimental confirmation of fuel rod thermocouple attachment response to a combination thermal and hydraulic loading cycle program consisting of 21-thermal cycles by heating in steam to $1100^{\circ} \mathrm{F}$ ( 1 cycle), $1400^{\circ} \mathrm{F}$ (5 cycles), $1500^{\circ} \mathrm{F}$ ( 5 cycles), $1600^{\circ} \mathrm{F}$ (5 cycles), and $1700^{\circ} \mathrm{F}$ ( 5 cycles); each cycle followed by bottom flooding. the rocin. test sample has 4 simulated rarige of acceptable weld characteristics.

11. Experimental confirmation of fuel rod thermocouple attachment corrosion behavior under the expected LOFT environment (borated water at 2500 psia and $650^{\circ} \mathrm{F}$ ) conditions.
Results

$\operatorname{ANC}^{[a]}$

The experiment results indicated that the weld characteristics of the 6.5-joule weld were satisfactory and the weld characteristics of the 4.0-joule welds were likely satisfactory based on the results of the abbreviated program.

Anc $^{[a]}$

This is a routine experimental progran to confirm the stress and corrosion capabilities of the weld design. Recent results indicated that a new weld design based on 4.0 joules, 275 spot size, and 40 aperature was unsatisfactory.

A.rc $[\mathrm{a}]$ This is a routine test of the long-term weld corrosion characteristics. Recent results indicated that the expected lifetime of the welds in the LOFT reactor would be about 6000 hours. . .
ANC LTR-141-6, "LOFT Heater Pin Tpermocouple Attachment Testing", May 17, 1973[a]].

ANC letter report, "Tube Furnace Thermal Cycle Tests, Mes-1-73", January 5, $1973[a]$ Recent test results to be published.
ANC LTR 1.4.1-29, "Autoclave Life Tests of LOFT Fuel Rpd Thermocouple Welds", March 13,1975 [a] 


\section{TA.BLE IV (continued)}

\begin{tabular}{|c|c|c|c|c|}
\hline Purpose. & & $\begin{array}{c}\text { Performing } \\
\text { Organization }\end{array}$ & $\cdot \cdot \cdot$ & Documentation \\
\hline \multicolumn{5}{|c|}{$\begin{array}{l}\text { 1. Fuel Bundle Instrumentatizn Attachment } \\
\text { (continued) }\end{array}$} \\
\hline $\begin{array}{l}\text { 12. Predict the maximum stresses } \\
\text { under Items } B .3 \text { anc C. } 9 \text {. loading } \\
\text { conditions for the following } \\
\text { components: } \\
\text { a. Coolant thermocciuple hot } \\
\text { junction } \\
\text { b. Guide tute } T / C \text { cable spans } \\
\text { c. Fuel rod } T / C \text { catile spans. }\end{array}$ & - & MPR & $\begin{array}{l}\text { The study concludes thet the compenents } \\
\text { evaluated meet ASME roc.s requirements } \\
\text { under tha worst case LCICE and seigmic } \\
\text { loading zonditions. }\end{array}$ & $\begin{array}{l}\text { MPR report, "MPR-509, Report of LOFT Fuel } \\
\text { Module Dynamic Analyses", Volume III, } \\
\text { Section B.6, March 1976." } \\
.\end{array}$ \\
\hline \multicolumn{5}{|l|}{ J. Upper Structure Instrumenzation } \\
\hline $\begin{array}{l}\text { 1. Predictians of stresses, during } \\
\text { normal operating, LOCE, and LOCA } \\
\text { conditions for the following } \\
\text { components: } \\
\text { a. Density-velocity detec-or } \\
\text { mounting bracket } \\
\text { b. Dens ity-velocity detec-or } \\
\text { mounting flange (including: } \\
\text { fastener counter bare) } \\
\text { c. Type } C \text { upper structure } \\
\text { window-frame cutout for } \\
\text { density-velocity cetector } \\
\text { bracket } \\
\text { d. Type A upper structure } \\
\text { window-frame cutout for } \\
\text { density-velocity detector } \\
\text { e. Type A density-velocity } \\
\text { detector cable conduit } \\
\text { f. Type A density-velocity } \\
\text { detector cable conduit stésles } \\
\text { g. Free-field pressure det?ctor } \\
\text { mounting flange } \\
\text { h. Displacement transducer } \\
\text { bolt preload } \\
\text { i. l/4-in. cap screw } \\
\text { j. l/4-, 3/8-, and } 3 / 4-i n \text {. } \\
\text { capscrew locking cups. }\end{array}$ & & MPR & $\begin{array}{l}\text { The analyses predicted that the des:ign } \\
\text { of all components was adequate for normal } \\
\text { operating, LOCE, and LCCA conditions with } \\
\text { one excejtion which was corrected by addin } \\
\text { a stratejicaily locatec Type A dens ty- } \\
\text { velocity detector cable conduct support. } \\
\qquad \begin{array}{c}\text { : } \\
\text { : }\end{array}\end{array}$ & $\begin{array}{l}\text { MPR letter report, "Design Analysis for Up- } \\
\text { per Core Support Structure Replaceable In- } \\
\text { struments", May } 21 \text {, 1973. }\end{array}$ \\
\hline
\end{tabular}




\section{TABLE IV (continued)}

Purpose

Performing

Organization

MPR

2. Predict the maximum stresses

uncer Item $C .9$ loading condi-

tions for the center fuel module

derisity-velocity detector cable

conduit, conduit clips, and

3. Predict the maximum stresses

under Item C. 9 loadira condi-

tians for the following com-

ponents:

1. Center fuel module

a. Flux scan tube

blux scan tube bracket and fasteners.

2. Corner fuel module

a. Pressure tubes

b. Pressure and cable con-

duit tube clips and welds

c. Flux scan tube, tube

brackets, and fasteners.

[a] ANC is now EG\&G Idaho, Inc.

Results

Documentation

The study concluded the components evaluated meet the applicable ASME stress requirements.

MPR report, "MPR-509, Report of LOFT Fuel Module Dynanic Analysis", Volume III, Section B.4. Narch 1976 .

The study concluded that the components meet the applicable ASME code stress requirements except for:

a. Corner fuel module flux scan tube fasteners

b. Center fuel module flux scan tube. Recommendations were made to reduce the fastener torque to $3.5 \mathrm{ft}-1 \mathrm{~b}(8.1 \mathrm{ft}-1 \mathrm{~b}$ specified) and raise the flux scan tube natural frequency of vibration by improvement in the support arrangement. 
(3) Predict worst case LOCE event guide tube temperature conditions with MOXY computer code

(4). Incorporate FRAP-T features into MOXY computer code and predict core-wide region of fuel rod damage during planned LOCE events with MOXY/SCORE computer codes

(5) Predict fuel rod cladding mechanical response to planned LOCE events at local worst case fuel rod positions with existing computer code.

The LOFT test data will be compared to the analytically predicted responses and appropriate code adjustments made for improved prediction capability.

\section{MISCELLANEOUS DESIGN}

The total design program effort also included some design activities classified as miscellaneous. These activities are of interest since the purposes of some were to determine fundamental material properties at high temperatures. Table V is a summary of these design activities. 


\section{TABLE V}

LOFT FUEL MODULE MISCELLANEOUS DESIGN ACTIVITIES

\section{Purpose}

A. Fuel Rod Cladding -- Determine the rat and amount of annealing of LOFT coldworked zircaloy cladding when exposed to temperatures $\left(800\right.$ to $\left.1800^{\circ} \mathrm{F}\right)$ exprected in LOCES.

B. Cor.trol Rod Poison -- Determine the furdamental material properties of melting temperature, and coefficient of expansion near the melting temperature of the LOFT $80 \mathrm{hg}-15 \mathrm{In}-5 \mathrm{Cd}$ poison material.

C. Coritrol Rod Poison -- Determine the compatibility of the $80 \mathrm{Ag}-15 \mathrm{In}-5 \mathrm{Cd}$ LOFT poison material with Type 304 SS at expected LOCE temperatures $\left(1400\right.$ to $\left.2000^{\circ} \mathrm{F}\right)$

D. Fuel Bundle Components -- Evaluate electrical discharge machining (EDM) as a technique for machining in-core components.
Performing Organization

ANC [a]

BMI

EUC
Results

The experimental results indicated that rapid annealing would occur in the 1100 to $1200^{\circ} \mathrm{F}$ range with more rapid rates up to $7500^{\circ}$ where instantaneous (less than $1 \mathrm{sec}$ ) annealing was indicated.

The experimental results indicated the following properties:

Melting temperature -- 1472 to. $1562^{\circ} \mathrm{F}$

Volume expansion in melting -- 5.4\%

Thermal expansion coefficient after melting - $3.83 \times 10-2$ in./in.

$\left(1562\right.$ to $\left.1859^{\circ} \mathrm{F}\right)$

Thermal expansion below melting tem-

perature - $13.3 \times 10^{6} \mathrm{in./in.}{ }^{\circ} \mathrm{F}$.

The experimental results indicated that the poison rod alloy and 304 SS are compatible.

The combined literature information evaluation, corrosion tests and metallurgical investigation indicated the EDM is an acceptable machining technique.

\section{Documentation}

ANC LTR 1.1.1.1-4, "Zircaloy-4 Annealing Study", October 29, 1974[a].

ANC LTR 1.1.1.1-15, "Experimental Determination of Behavior of the $\mathrm{Ag}-\mathrm{In}-\mathrm{Cd}$ Poison Rod Alloy at Expected LOCE Temperatures", February 1975[a].

Same as above.

Exxon report "JN-72-21, Evaluation of Electrical Discharge as a Te:chnique for Machining In-Core Components", September 8,1972 .

[a] ANC is now EG\&G Ideho, Iric. 


\section{FABRICATION PROGRAM}

The fabrication for the LOFT fuel modules is based on the following objectives:

(1) Preproduction process demonstration of all difficult fabrication processes and measurement techniques

(2) Characterization of the fuel module with emphasis on characteristics that could influence the fuel bundle response during the LOCE

(3) Fabrication program based on the quality assurance requirements of RDT Slanilaid $\Gamma 2-2$.

\section{PREPRODUCTION PROCESS DEMONSTRATION PROGRAM}

The preproduction process demonstration program for fabrication processes was comprehensive and thorough. The program performed for fuel bundle fabrication at Exxon is summarized in Table VI. Similar comprehensive programs were performed -- for the upper support structures by L\&S Machine Co. and for the instrumentation penetration assemblies and fuel module assembly by EG\&G Idaho, Inc.

The process demonstration programs were effective in identification of unsatisfactory design and fabrication conditions and confirming that the corrective action was satisfactory.

The qualification/demonstration programs for measurement techniques were also comprehensive and thorough. Table VII is a summary of some of these qualification activities which are of special interest because of the unique character of the inspection. All equipment and inspection equipment operators are covered by a comprehensive program to maintain equipment accuracy and operator skills.

\section{CHARACTERI7.ATION}

The fuel module characterization is designed to provide (a) traceability to raw materials, fabrication processes, inspection techniques, and participating personnel, (b) measurement of characteristics which could influence the fuel bundle response during its use in the LOFT experimental program, and (c) measurement of characteristics required to demonstrate that the components satisfy the agreed upon specifications. Table VIII is a summary of some of the more important fuel bundle characteristics which have been or will be determined and recorded. The laser-Doppler determination of the fuel bundle flow 
TABLE VI

LOFT FUEL BUNDLE FABRICATION PROCESS QUALIFICATIONS/DEMONSTRATIONS PROGRAM

\begin{tabular}{|c|c|c|c|}
\hline Purpose & $\begin{array}{c}\text { Performing } \\
\text { Organization } \\
\end{array}$ & Results & Documentation \\
\hline $\begin{array}{l}\text { 1. Fuel rods } \\
\text { a. End cap welds (WP-27 and }-61 \\
\text { b. Rotary fuel pelle } \\
\text { c. Fuel rod assembly } \\
\text { d. Fuel rod pressurization }\end{array}$ & $\begin{array}{l}\text { ENC } \\
\text { ENC } \\
\text { ENC } \\
\text { ENC }\end{array}$ & $\begin{array}{l}\text { Satisfactory ( } 40 \text { welds each) } \\
\text { Satisfactory ( } 507 \text { pellets) } \\
\text { Satisfactory ( } 6 \text { rods) } \\
\text { Satisfactory after a design modification } \\
\text { to prevent contamination of the seal weld } \\
\text { with spatter from the Inconel pellet } \\
\text { holddown spring. }\end{array}$ & $\begin{array}{l}\text { Exxon reports, } 7 / 8 / 72(\text { WP-27) and } 9 / 17 / 73 \\
\text { (WF-61). } \\
\text { Exxor report, } 6 / 2 / 72 \text {. } \\
\text { No report ava ilable. } \\
\text { Exxon report, "XN-145, LOFT Prepres- } \\
\text { surization Process Demonstration", } \\
\text { August } 1973 \text {. }\end{array}$ \\
\hline $\begin{array}{l}\text { 2. Fuel Bundle Skeleton } \\
\text { a. Guide tube sleeve weld (WP-39) } \\
\text { b. Guide tube sleeve edge weld (WP-40) } \\
\text { c. Guide tube lower end weld (WP-41) } \\
\text { d. } 15 \times 15 \text { spacer grid intersection } \\
\text { joint welds, end tab weld, and } \\
\text { corner overlap weld (SP-114) } \\
\text { e. } 15 \times 15 \text { spacer grid assembly } \\
\text { (SP-114) } \\
\text { f. Corner spacer grid assembly } \\
\text { (SP-117) } \\
\text { g. Spacer grid locking ring weld } \\
\text { (WP-50) } \\
\text { h. Instrumentation tsbe plug weld } \\
\text { (WP-42) }\end{array}$ & $\begin{array}{l}\text { ENC } \\
\text { ENC } \\
\text { ENC } \\
\text { CARAN } \\
\text { CARAN } \\
\text { CARAN } \\
\text { ENC } \\
\text { ENC }\end{array}$ & $\begin{array}{l}\text { Satisfactory ( } 6 \text { samples) with rework to } \\
\text { correct alignment } \\
\text { Satisfactory ( } 6 \text { samples) } \\
\text { Satisfactory ( } 16 \text { samples) with rework to } \\
\text { correct alignment } \\
\text { Satisfactory ( } 10 \text { samples each) after } \\
\text { changes were made to eliminate porosity } \\
\text { in weld centers } \\
\text { Satisfactory ( } 1 \text { assembly) after design } \\
\text { changes were made to center strips in } \\
\text { slots during welding } \\
\text { Satisfactory. (one) } \\
\text { Satisfactory ( } 6 \text { samples) } \\
\text { Satisfactory ( } 6 \text { samples) }\end{array}$ & $\begin{array}{l}\text { Exxon report, } 2 / 20 / 73 \text {. } \\
\text { Exxon report, } 1 / 30 / 73 \\
\text { Exxon report, } 2 / 20 / 73 \text {. } \\
\text { Caran report, } 8 / 19 / 72 \\
\text { Caran report, } 8 / 19 / 72 \\
\text { No report available. } \\
\text { Exxon report, } 9 / 3 / 74 \\
\text { Exxon report, } 2 / 5 / 73 \text {. }\end{array}$ \\
\hline $\begin{array}{l}\text { 3. Fuel Bundle End Boxes } \\
\text { a. Upper ( } 15 \times 15 \text { ) e.7d box 90-degree } \\
\text { corner weld (LSWP-1) } \\
\text { b. Upper (corner) end box 45-degree } \\
\text { corner weld (LSWP-3) }\end{array}$ & $\begin{array}{l}\text { L\&S } \\
\text { L\&S }\end{array}$ & $\begin{array}{l}\text { Satisfactory (2 samples) } \\
\text { Satisfactory (2 samples) } \\
\begin{array}{cc}\because & \because \therefore:\end{array}\end{array}$ & $\begin{array}{l}\text { L\&S report, March } 1973 . \\
\text { L\&S report, March } 1973 .\end{array}$ \\
\hline
\end{tabular}




\section{TABLE VI (continuedi}

Performing

\section{Purpose}

3. Fuel Bundle End Boxes (continued) c. Upper end box side plate to collar weld (LSWP-2)

4. Fuel Bundle instrumentatior Attaciment a. Guide tube thermoccuple to guide

- tube attachment laser weld (WP-ICl)

b. Guide tube assembly suprort to tube weld (WP-44) ring weld (WP-45)

Liquid level routing fi>ture gusset and lock velds (WP-46)

e. Coolant thermocouple hot junction attachment to tie filate (metal urset)

. Instrument cable bindle staple weld (WP-59)

g. Lower tie plate to $T / C$ cover plate weld (WP-52)

$h$. Thermocouple seai weld (WP-56)

$i$. Fuel rod thermocouple attachment laser weld

$j$. Fuel rod/tie piaze fasterer system (including metal ups $\equiv t$ )

k. Guide tube instrumentati $=n$ assembly

\section{Organization}

L8S

ENC

ENC

ENC

[NC

INC

ENC

ENC

ENC

ENC

ENC

ENC
Results

jétisfäctory (1 sample)

כ̇atisfactory (12 samples)

jettisfactory ( 16 welds)

jetisfactory ( 8 welds)

jEtisfactory ( 6 samples)

j三tisfactory (4 samples)

$\vdots \equiv$ tisfactory ( 6 samples! afte- improvenents for minimizing instrume 7 cable ieating

jEtisfactory (14 samples)

j三tisfactory (12 samples)

jEtisfactory ( 7 full length, A $T / C$ samples JEr machine) after numerous a $T / C$ sample erovements over a 3 -year period. Jrovements over a 3-year perisd. To date, afproximately 6 full-length $p{ }^{2}$ units, many - inch Frocess requalification units and J prototypes have been fabri sated as part Jr the tctal process denonstration program s:tisfactory ( 3 samples

Jre satisfactory assembiy per model
Exxon report, $3 / 73$.

Documentation

L\&S report, March 1973.

Exxon report, 3/12/73

Exxon report, 2/5/73.

Exxon report, 3/1/73.

Exxon report, 3/19/73

Exxon report, $4 / 73$.

Exxon report, 3/22/74

Exxon report, $2 / 13 / 73$

Exxon report, $2 / 8 / 73$.

Exxon reports: 


\section{TABLE VI (continued)}

\section{Purpose \\ Performing \\ Organization}

4. Fuel Bundle Instrumentation Attachment (continued) (1) Type $B$ instrumentation tube model

(2) Two coolant thermocsuple models

(3) Four coolant thermocouple models

(4) Fixed flux detector mode 1

(5) One guide tube $T / C$ node 1

(6) Four guide tube $T / C$ models.

5. Fuel Bundle Assembly

a. Upper tie plate to end box weld ENC (WP-49)
ENC (WP-88)

c. Fuel burdle assembly plug weld (in- ENC cluding pins and Jowels) (WP-89) ENC

d. Center $(15 \times 15)$ fuel bundle prototype

e. Corner instrumented fue] bundle ENC prototype
Results

\section{Documentation}

(1) To be published

(2) $2 / 8 / 75$
(3) $2 / 8 / 75$
(4) No report available
(5) $2 / 8 / 75$
(6) To be publ ished.

Satisfactory (8 samples)

Satisfactory (approximately 8)

Satisfactory (approximately 8)

Successful (l complete unit) -- The result indicated the following improvements were necessary or desirable:

. ANC[a] furnished titanium-sheathed thermocouple quality

2. Fuel rod thermocouple attachment technique

3. Instrument cable bundle attachment to upper end box

4. Liquid level detector alignment

5. Lower end box thermocouple positioning

6. Skeleton alignment

7. Guide tube locking ring welding

Successful (l complete unit) -- The results Exxon monthly report for July 1973.

indicated satisfactory improvement of I tems

through 5 above and indicated the following

through 5 above and indicated the following

1. Guide tube locking ring welding

2. Assembly shop management

3. Skeleton alignment tilt (caused by

inherent triangular shaped sensitivity)
Exxon report, 3/1/73.

Exxon report, $1 / 22 / 75$

Exxon report, $10 / 7 / 74$

Exxon monthly report for January 1973. 
TABLE V: (continued)

\section{Purpose}

5. Fuel Bundle Assembly (cont" ined)

\section{f. Control $(15 \times 15)$ fuel bund e} prototype.

6. Control Rod Assembly
Per=orming Organization

\section{$-$}

a. Control rod end fitting sea: weld

b. Control rod to spider piug veld (WP-55)

c. Extension shaft weld (WP-58,

d. Control rod assembly.

7. Neutron Source Assembly.

8. Fuel Bundle Packaging and Shipoing.

ENC
Results

Documentation

4. Skeleton alignment twist (causec by guide sube residual torque introduced by, nut torquing)

5. Cleara ice and access to lower end box guide : tube nuts

6. Weldin.j head access to peripherál spacer grid locking rings

ENC Suzcessful 1 noninstrumented unit mock-

up) -- The results indicated satisfactory

imoroveme it of Items 5.d. 6 and $?$ end 5.e. end 4 above.

Satisfactory (14 samples)

Exxon report $6 / 10 / 74$.

Satisfact.ory (10 welds)

Satisfactiory (3 samples)

Suzcessful (2 prototypes) -- The results

inficated that improvements were desir-

abie in roducing porosity in the spider

ab-ie in roducing porosity in the spider
raw material and spider surface finish.

Suzcessful (1 complete prototype) --

The results indicated improvenents were desirable for positioning the tube-toshaft crimping tool.

vo report available.

Successful 11 instrumented $(15 \times 15)$ control vo report available.

fuei bundle mockup] -- The results indicated

improveme its were desirable in shipping

container cleanliness: inside (before

pazkaging) and outside (during transport);

and assuring all support equipment was

installed.
Exxon report $4 / 3 / 74$

Exxon report $6 / 13 / 73$.

\section{jame, as Item 5.e.}

[a] ANC is now EG\&G Idaho, Ine. 


\section{TABLE VII}

LOFT FUEL MODULE SPECIAL INSPECTION TECHNIQUE PROCESS DEMONSTRATIONS

Inspection Device;'Technique

A. LOFT fuel bundle and RCC alignment vertical gaje

B. LOFT fuel bundle rod-to-rod inspection gace

C. Fue 1 peliet diameter automatic inspection instrument

D. Fuel rod thermocouple attachment weld torque tests

[a] ANC is now EG\&G Idaho, Inc.
Performing

Organization

EVC

ENC

ENC

ENC $[a]$

\section{Results}

Satisfactory demonstration of repeatability ENC report, March 1973. on a center fuel bundle prototype.

Satisfactory comparison of measured versus ENC report, March 1973. actual dimensions in a typical. $15 \times 15$ configuration.

Satisfactory rejection of 10 oversize and 10 undersize pellets mixed into a batch

of acceptable pellets.

Numerous test results developed a meaning

ful correlation between the torque test

results and the thermal-cycling (strength)

capabilities of the weld.
ENC report, $5 / 2 z / 71$

No report available. 


\section{TABLE VIII}

AS-BUILT LCFT FUEL BLNCLE CHARACTERISTICS TO BE DOCUMENTED

\begin{tabular}{|c|c|c|c|}
\hline Item & Characteristics & Values & Notes \\
\hline \multirow[t]{15}{*}{ A. Fuel Bundle } & 1. Weight & $N A$ & Actual value \\
\hline & 2. Length & $78.568 \pm 0.060$ in. & Tabulate actual dimension \\
\hline & 3. Envelope & & \\
\hline & a. Square & 8.449 in. square & $\begin{array}{l}\text { Must fit full length with bottom } \\
\text { centered }\end{array}$ \\
\hline & b. Corner & $\begin{array}{l}7.429 \text { in. legs } x \\
.10 .506 \text { in. hypotenuse }\end{array}$ & $\begin{array}{l}\text { Must fit full length with bottom } \\
\text { centered }\end{array}$ \\
\hline & $\begin{array}{l}\text { 4. End surface } \\
\text { squareness }\end{array}$ & Parallel to 0.005 in. & Certification of compliance \\
\hline & $\begin{array}{l}\text { 5. Spacer grid } \\
\text { spacing }\end{array}$ & $16.60 \pm 0.06$ in & Certification of compliance \\
\hline & 6. Pressure drop & Determined by test & Actual test data. \\
\hline & 7. Flow distributior & Determined by test & Actual test data \\
\hline & 8. Strength & Determined by test & Actual test data \\
\hline & $\begin{array}{l}\text { 9. Flow vibration } \\
\text { sensitivity }\end{array}$ & Determined by test & Actual test data \\
\hline & 10. DNB & Determined by test & Actual test data \\
\hline & 11. Flow mixing & Determined by test & Actual test data \\
\hline & $\begin{array}{l}\text { 12. Control rod drop } \\
\text { time }\end{array}$ & $\begin{array}{l}75 \% \text { of travel in } 2 \mathrm{sec} \\
100 \% \text { of travel in } 3 \mathrm{sec}\end{array}$ & $\begin{array}{l}\text { Determined by test, actual test } \\
\text { data }\end{array}$ \\
\hline & 13. Rod-to-rod spacing & 0.120 in. min & $\begin{array}{l}\text { Determined with electronic device, } \\
\text { Certification of compliance }\end{array}$ \\
\hline
\end{tabular}


TABLE VIII (continued)

\begin{tabular}{|c|c|c|c|}
\hline Item & Characteristics & Values & Notes \\
\hline \multirow[t]{13}{*}{ B. Each Component } & $\begin{array}{l}\text { 1. Chemical Composition: } \\
\text { a. Fuel pellet }\left(\mathrm{UO}_{2}\right)\end{array}$ & $\begin{array}{l}\text { Stoichiometric } 2.00 \text { to } \\
2.02 \text { oxygen to uranium } \\
\text { ratio, } 4.00 \% \text { enrichment }\end{array}$ & Actual value per lot \\
\hline & b. Fuel rod cladding & $\begin{array}{l}\text { ASTM B } 351 \text { GR RA-2 } \\
(2 r-4)\end{array}$ & Actual value per lot \\
\hline & $\begin{array}{l}\text { c. Fuel rod } n- \\
\text { sulating washer }\end{array}$ & $99.3 \%$ pure $\mathrm{Al}_{2} \mathrm{O}_{3}$ & Actual value per lot \\
\hline & $\begin{array}{l}\text { d. Fuel rod spring } \\
\text { (Inconel } x-750 \text { ) }\end{array}$ & AMS-5698B or $5699 B$ & Actual value per lot \\
\hline & $\begin{array}{l}\text { e. Fuel rod end } \\
\text { fittings }\end{array}$ & $\begin{array}{l}\text { ASTM B351 GR RA-2 } \\
(2 r-4)\end{array}$ & Actual value per lot \\
\hline & $\begin{array}{l}\text { f. Spacer grid } \\
\text { straps }\end{array}$ & AMS 5596 C (Inconel 718) & Actual value per lot \\
\hline & g. Locking rings & ASTM A 213 (304 L SS) & Actual value per lot \\
\hline & h. Guide tube & ASTM A 213 (304 L SS) & Actual value per lot \\
\hline & i. Guide tube fitting & ASTM A 276-70 (304 L SS) & Actual value per lot \\
\hline & j. End boxes & ASTM A $240-70(304 \cdot L$ SS) & Actual value per lot \\
\hline & $\begin{array}{l}\text { k. Miscellaneous fuel } \\
\text { bundle components }\end{array}$ & Mostly 304 L SS & Actual value per lot \\
\hline & $\begin{array}{l}\text { 1. Control rod } \\
\text { poison }\end{array}$ & $80 \% \mathrm{Ag}, 15 \%$ In, $5 \% \mathrm{Cd}$ & Actual value per lot \\
\hline & $\begin{array}{l}\text { m. Control rod } \\
\text { cladding }\end{array}$ & ASTM A-213 (304 L SS) & Actual value per lot \\
\hline
\end{tabular}


TABLE VIII (continued)

\begin{tabular}{|c|c|c|c|}
\hline Item & Characteristics & Values & Notes \\
\hline \multirow{4}{*}{$\begin{array}{l}\text { B. Each Comsonent } \\
\text { (continued) }\end{array}$} & n. Control rod spring & AMS -5698 or $5699 B$ & Actual value per lot \\
\hline & $\begin{array}{l}\text { D. Control rod end } \\
\text { f-tting }\end{array}$ & ASTM A 276-70 (304 L SS) & Actual value per lot \\
\hline & p. Control rod spider & ASTN A $240-70$ (304 L SS) & Actual value per lot \\
\hline & $\begin{array}{l}\text { q. M- scellaneous con- } \\
\text { trol rod components }\end{array}$ & Mostly 304 L SS & Actual value per lot \\
\hline \multirow[t]{9}{*}{$\begin{array}{l}\text { C. Fuel Pellet } \\
\text { Drawing No. } \\
\text { JN } 300343\end{array}$} & $\begin{array}{l}\therefore \text { [mpurities: } \\
\text { Individual } \\
\text { Tota: gasecus }\end{array}$ & $\begin{array}{l}\text { JN } \subseteq 30061, \text { Appendix }: B \\
0.1 \mathrm{C} \mathrm{cc} / \mathrm{g}\end{array}$ & $\begin{array}{l}\text { Value for each lot } \\
\text { vacuum outgassing at } 3000^{\circ} \mathrm{F} \text {, } \\
\text { value for each lot }\end{array}$ \\
\hline & $\begin{array}{l}\text { Moiszure } \\
\text { Boron equivalent }\end{array}$ & $\begin{array}{l}20 \text { fpm max } \\
3 \text { ppm max }\end{array}$ & $\begin{array}{l}\text { Value for each lot } \\
\text { Value for each lot }\end{array}$ \\
\hline & 2. Jiameter & $0.36 .59 \pm 0.0005$ in. & Certification of compliance \\
\hline & 3. - eng $=h$ & $0.600 \pm 0.025 \mathrm{in}$ & Certification of compliance \\
\hline & 4. Perpendicularity & End surface $\perp 0.005$ in. & Certification of compliance \\
\hline & 5. Jish geometry & $\begin{array}{l}0.4 \hat{c} 0 \text { in. spherical } \\
\text { (both ends) }\end{array}$ & Certification of compliance \\
\hline & $\begin{array}{l}\text { E. Jefects (chips, } \\
\text { zracks) }\end{array}$ & $\begin{array}{l}\text { See JN-S30061, } \\
\text { Paragraph } 3.5 .3\end{array}$ & Certification of compliance \\
\hline & ?. Jensity & $93 \pm 1.5 \%$ thecretical & Certification of compliance \\
\hline & c. Surface finish & $\sqrt[63]{ }(\mathrm{RMS})$ & Certification of compliance \\
\hline $\begin{array}{l}\text { D. Fuel Rod } \\
\text { Cladding } \\
\text { JN } 300336\end{array}$ & $\begin{array}{l}\text { 1. Impurities: } \\
\text { Indi vidual } \\
\text { Fini shed product } \\
\text { Boron equivalent }\end{array}$ & $\begin{array}{l}\mathrm{JN}-\$ 30084, \text { ApFendix C } \\
\mathrm{N}_{2}, \mathrm{H}_{2}, \mathrm{O}_{2}, \mathrm{C} \\
40 \mathrm{ppm} \max \end{array}$ & $\begin{array}{l}\text { Value for each lot } \\
\text { Value for each lot } \\
\text { Value for each lot }\end{array}$ \\
\hline
\end{tabular}


TABLE VIII (continued)

\begin{tabular}{|c|c|c|c|}
\hline Item & Characteristics & Values & Notes \\
\hline \multirow{10}{*}{$\begin{array}{l}\text { D. Fuel Rod } \\
\text { Cladding } \\
\text { JN } 300336 \\
\text { (continued) }\end{array}$} & $\begin{array}{l}\text { 2. Tensile properties } \\
\text { ambient to } 650^{\circ} \mathrm{F}\end{array}$ & $\begin{array}{l}\text { JN S30084, Paragraph } \\
3.5 .2\end{array}$ & Value for each lot \\
\hline & 3. Flare & $\begin{array}{l}\text { JN S30084, Paragraph } \\
3.5 .3\end{array}$ & Value for each lot \\
\hline & 4. Burst & $\begin{array}{l}\text { JN S30084, Paragraph } \\
3.5 .4\end{array}$ & Value for each lot \\
\hline & 5. Defects & $\begin{array}{l}0.002 \text { in. deep } \times 0.004 \\
\text { in. wide } x 0.125 \text { in. } \\
\text { long } \max \end{array}$ & $\begin{array}{l}\text { Certification of compliance } \\
\text { (test on each tube) }\end{array}$ \\
\hline & 6. Grain size & $\begin{array}{l}\text { Size } 7 \text { longitudinal, } \\
8 \text { transverse (max) }\end{array}$ & Value for each lot \\
\hline & 7. Hydride orientation & $F_{N}$ less than 0.30 & Value for each lot \\
\hline & $\begin{array}{l}\text { 8. Corrosion } \\
\text { resistance }\end{array}$ & $\begin{array}{l}\text { Weight gain per } \\
\text { ASTM B } 353\end{array}$ & Value for each lot \\
\hline & 9. Wall thickness & 0.0228 in. $\min$ & $\begin{array}{l}\text { Value for each center assembly } \\
\text { tube. Certification of compli- } \\
\text { ance for others }\end{array}$ \\
\hline & 10. Inside diameter & $0.3734 \pm 0.0015 \mathrm{in}$. & $\begin{array}{l}\text { Value for each center assembly } \\
\text { tube. Certification of compli- } \\
\text { ance for others }\end{array}$ \\
\hline & 11. Outside diámeter & $0.4240 \pm 0.0015 \mathrm{in}$. & $\begin{array}{l}\text { Value for each center assembly } \\
\text { tube. Certification of compli- } \\
\text { ance for others }\end{array}$ \\
\hline
\end{tabular}


TA3LE VIII (continued)

\begin{tabular}{|c|c|c|c|}
\hline Item & Characteristics & Values & Notes \\
\hline $\begin{array}{l}\text { D. Fuel Rod } \\
\text { Cladding } \\
\text { JN } 300335^{5} \\
\text { (continued) }\end{array}$ & $\begin{array}{l}\text { 12. Stréightness } \\
\text { 13. Surface finish }\end{array}$ & $\begin{array}{l}0.015 \text { in. in } 12 \text { in. } \\
32 \sqrt{\max }\end{array}$ & $\begin{array}{l}\text { Certification of compliance } \\
\text { Certification of compliance }\end{array}$ \\
\hline \multirow[t]{7}{*}{$\begin{array}{l}\text { E. Fuel Rod End } \\
\text { Caps }\end{array}$} & $\begin{array}{l}\text { 1. Impurities: } \\
\text { Ind:vidual } \\
\text { Finished Froduct } \\
\text { Boron equivalent }\end{array}$ & $\begin{array}{l}\text { JN } \leqq 30085, \text { Appendix C } \\
N, \vdash, 0 \\
40 \mathrm{Fpm} \max \end{array}$ & $\begin{array}{l}\text { Value for each lot } \\
\text { Value for each lot } \\
\text { Value for each lot }\end{array}$ \\
\hline & $\begin{array}{l}\text { 2. Tensile properties } \\
\text { ambient and } 650^{\circ} \mathrm{F}\end{array}$ & $\begin{array}{l}\text { JN } \subseteq 30085 \text {, Paragraph } \\
3.5 .3\end{array}$ & Value for each lot \\
\hline & 3. Hardness & Rockwell $392 \max$ & Value for each lot \\
\hline & 4. Defects & $\begin{array}{l}0.005 \text { in. deep } \times 0.004 \\
\text { in. wide } \times 0.125 \text { in. } \\
\text { long max }\end{array}$ & $\begin{array}{l}\text { Also } 0.0136-\text { in: diameter hole } \\
\text { Value for each rod or bar }\end{array}$ \\
\hline & 5: Grain size & $\begin{array}{l}\text { Size } 7 \text { max longitudina } \\
\text { and transverse }\end{array}$ & Value for each lot \\
\hline & 6. Corrosion resistance & $\begin{array}{l}\text { Weight gain per ASTM } \\
\text { B } 351\end{array}$ & Value for each lot \\
\hline & 7. Dimensions & $\begin{array}{l}\text { Drawings JN-300460 and } \\
\text { JN-300436 }\end{array}$ & Certification of compliance \\
\hline $\begin{array}{l}\text { F. Fuel Rod In- } \\
\text { sulating } \\
\text { Washer } \\
\text { JN } 300337\end{array}$ & $\begin{array}{l}\text { 1. Impurities: } \\
\text { Individual } \\
\text { Total gases } \\
\text { Moisture content } \\
\text { Boron equivalent }\end{array}$ & $\begin{array}{l}\text { JN } \$ 30067 \text { Paragraph } 3.22 \\
0.05 \mathrm{cc} / \mathrm{g} \\
35 \text { ppm max } \\
76 \text { Ppm max }\end{array}$ & $\begin{array}{l}\text { Value for each lot } \\
\text { Vacuum outgas at } 3000^{\circ} \mathrm{F} \text {, value for } \\
\text { each lot } \\
\text { Value for each lot } \\
\text { Value for each lot }\end{array}$ \\
\hline
\end{tabular}


TABLE VIII (continued)

\begin{tabular}{|c|c|c|c|c|}
\hline & Item & Characteristics & Values & Notes \\
\hline \multirow{3}{*}{ F. } & \multirow{3}{*}{$\begin{array}{l}\text { Fuel Rod In- } \\
\text { sulating Washer } \\
\text { J.V } 300337 \\
\text { (continued) }\end{array}$} & 2. Compressive strength & $250,000 \mathrm{psi}$ & Value for each lot \\
\hline & & $\begin{array}{l}\text { 3. Pits, chips, and } \\
\text { cracks }\end{array}$ & $\begin{array}{l}\text { JN } \$ 30067 \text {, Paragraphs } \\
3.3 .3 \text { and } 3.3 .4\end{array}$ & Certification of compliance \\
\hline & & 4. Dimensions & Drawing JN 300337 & Certification of compliance \\
\hline \multirow{4}{*}{ G. } & \multirow{4}{*}{$\begin{array}{l}\text { Fijel Rod } \\
\text { Plenum Spring } \\
\text { JN } 300338\end{array}$} & $\begin{array}{l}\text { 1. Boron equivalent } \\
\text { (impurities) }\end{array}$ & $1300 \mathrm{ppm} \max$ & Value for each lot \\
\hline & & $\begin{array}{l}\text { 2. Tensile properties } \\
\text { (wire) }\end{array}$ & $\begin{array}{l}\text { AMS } 5698 \text { B or AMS } \\
5699 \mathrm{~B}\end{array}$ & Value for each lot \\
\hline & & 3. Spring constant & $\begin{array}{l}10.4 \pm 1.4 \text { 1b/in. at } \\
3 \text { in. }\end{array}$ & Certification of compliance \\
\hline & & $\begin{array}{l}\text { 4. Dimensions (free } \\
\text { length, diameter, } \\
\text { etc.) }\end{array}$ & Drawing JN 300339 & $\begin{array}{l}\text { Certification of compliance } \\
(0.360 \pm 0.004 \text { in. dia, } 3.64 \pm \\
0.020 \text { in. free length) }\end{array}$ \\
\hline \multirow{7}{*}{\multicolumn{2}{|c|}{$\begin{array}{l}\text { H. Fuel Rod } \\
\text { Assembly } \\
\text { JN } 300453\end{array}$}} & $\begin{array}{l}\text { 1. Fi11 gas purity } \\
(99.9 \% \text { pure })\end{array}$ & $95 \%$ He min ( $5 \%$ Argon) & $\begin{array}{l}\text { Verify by process qualification, } \\
\text { certification of compliance }\end{array}$ \\
\hline & & 2. Pellet stack weight & $1134 \mathrm{~g} \max$ to $1112 \mathrm{~g} \min$ & Value for each stack \\
\hline & & 3. Pellet stack length & $66.000 \pm 0.125 \mathrm{in}$. & Value for each stack \\
\hline & & $\begin{array}{l}\text { 4. End cap weld } \\
\text { quality }\end{array}$ & $\begin{array}{l}\text { JN S30106, Paragraph } \\
3.3\end{array}$ & $\begin{array}{l}\text { Certification of compliance with } \\
100 \% \text { radiograph }\end{array}$ \\
\hline & & $\begin{array}{l}\text { 5. End cap weld } \\
\text { strength }\end{array}$ & $\begin{array}{l}\text { Joint efficiency } 80 \% \\
\text { clad strength }\end{array}$ & Verifý by process qualification \\
\hline & & 6. Plenum length & 3.00 in. & $\begin{array}{l}\text { Certification of compliance } \\
\text { w/radiographs on samples }\end{array}$ \\
\hline & & 7. Pellet seating & No space & $\begin{array}{l}\text { Certification of compliance } \\
\text { W/radiographs on samples }\end{array}$ \\
\hline
\end{tabular}


TABLE VIII (continued)

\begin{tabular}{|c|c|c|c|}
\hline Item & Chanacteristics & Values & Notes \\
\hline \multirow{5}{*}{$\begin{array}{l}\text { H. Fuel Roc } \\
\text { Assembly' } \\
\text { JN } 300463 \\
\text { (continued) }\end{array}$} & 8. Corrosion test & $\begin{array}{l}\text { Free of white and brown } \\
\text { corrosion }\end{array}$ & Ečcur rod \\
\hline & $\begin{array}{l}\text { 9. Pressure boundary } \\
\text { defects }\end{array}$ & $\underset{\mathrm{hr} / \max }{1 \times 10^{-8}}$ cc He/sec & (5C-micron vacuum) each rod \\
\hline & i0. Straightness & 0.015 in. in 12 in. & Certification of compliance \\
\hline & 1. Diameter & $0.4220 \pm 0.002$ in. & Certification of compliance \\
\hline & i2. Length & $70.380 \mathrm{in}$. & Value for each rod \\
\hline \multirow[t]{8}{*}{$\begin{array}{l}\text { I. Spacer Grid } \\
\text { JN } 300443 \\
\text { JN } 300440\end{array}$} & $\begin{array}{l}\text { 1. Boron equivalent } \\
\text { 2. Welds: }\end{array}$ & $1250 \mathrm{ppm} \max$ & Valce for each lot \\
\hline & a. Quality & $\begin{array}{l}\text { JN } 530154 \text {, Paragraph } \\
3.2 .2\end{array}$ & Certification of compliance \\
\hline & $\begin{array}{l}\text { b. Intersaction } \\
\text { weld l lad } \\
\text { capacity }\end{array}$ & Determined by test & Actual test data \\
\hline & 3. Tersile properties & Prozess control & S:eE JN S30154, Paragraph 3.2.3 \\
\hline & $\begin{array}{l}\text { 4. Assembly bearing } \\
\text { loc d capacity }\end{array}$ & Determined by tes: & $A=$ ival test data \\
\hline & $\begin{array}{l}\text { 5. Fuel rod spring } \\
\text { coristant }\end{array}$ & $\begin{array}{l}2.5 \text { lb at } 0.020-\text { in. } \\
\text { deflection }\end{array}$ & Cərtification of compliance \\
\hline & $\begin{array}{l}\text { 6. Guide tube spring } \\
\text { constant }\end{array}$ & $\begin{array}{l}2 \text { lb at } 0.10-i n . \\
\text { deflection }\end{array}$ & Car-ification of compliance \\
\hline & 7. Dimensions & See drawings & $\begin{array}{l}\text { Ce-ifications of compliance for } \\
\text { each spacer }\end{array}$ \\
\hline
\end{tabular}


TABLE VIII (continued)

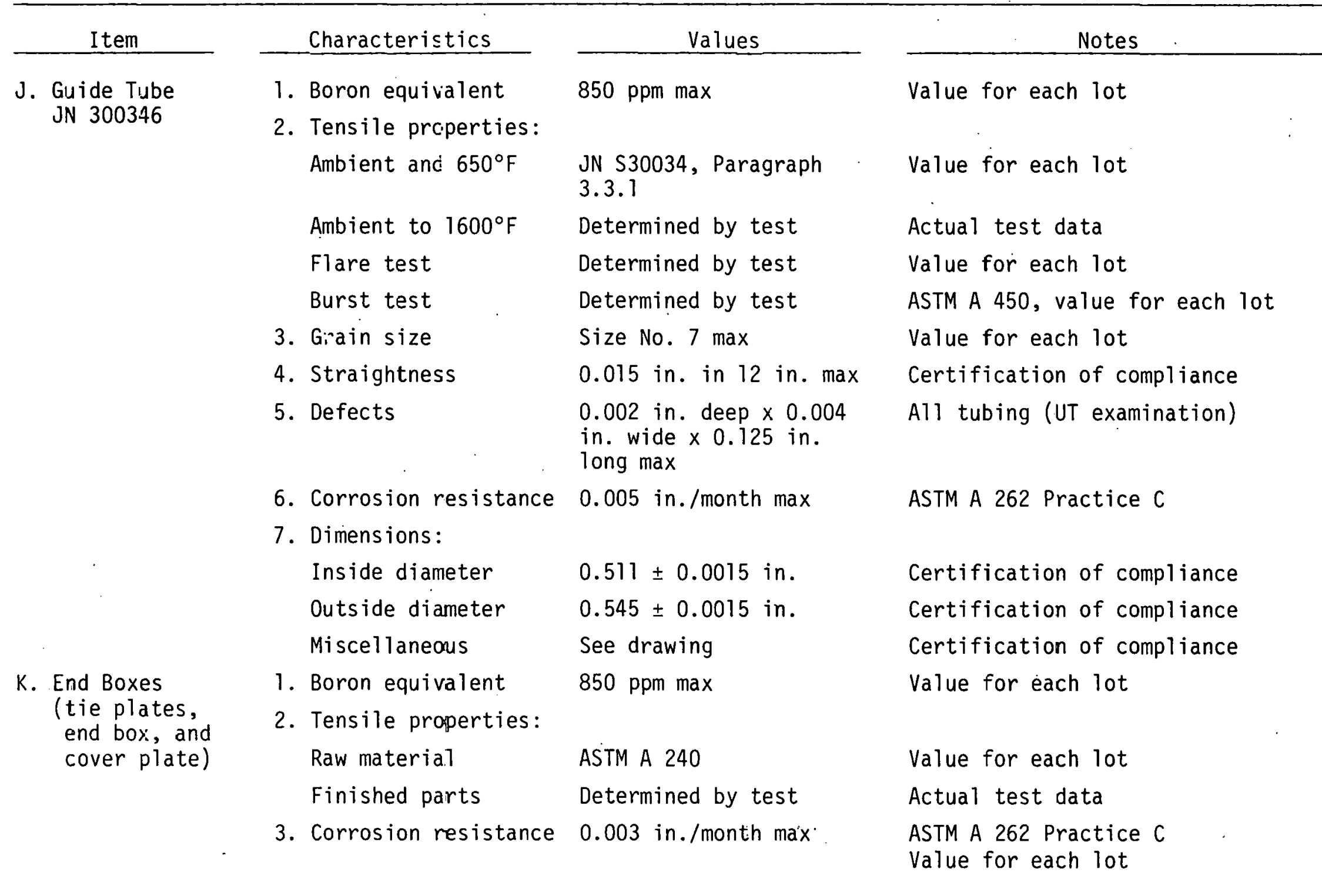


TABLE VIII (continued)

\begin{tabular}{|c|c|c|c|}
\hline Item & Characteristics & Values & Notes \\
\hline \multirow{3}{*}{$\begin{array}{l}\text { K. End Boxes } \\
\text { (tie plates, } \\
\text { end box, and } \\
\text { cover p ate) } \\
\text { (continued) }\end{array}$} & 4. Defects & $\begin{array}{l}\text { Max holes } 0.032-\text { in. dia- } \\
\text { meter at } 0.5 \text { in. from sur- } \\
\text { face and } 0.047-\text { in.-dia- } \\
\text { meter hole at } 3 \text { in. from } \\
\text { surface }\end{array}$ & Certification of compliance \\
\hline & 5. Weld quality & See dráwings & Certification of compliance \\
\hline & 6. Dimensions & See drawings & Certification of compliance \\
\hline \multirow{3}{*}{$\begin{array}{l}\text { L. Control Rod } \\
\text { Poison } \\
\text { JN } 300373\end{array}$} & 1. Impurities & JN S30220, Appendix B & Value for each lot \\
\hline & 2. Density & 9.5 to $10.3 \mathrm{~g} / \mathrm{cm}^{3}$ & Value for each lot \\
\hline & $\begin{array}{l}\text { 3. Dimensions (lengtר, } \\
\text { diameter, etc.) }\end{array}$ & See drawing & $\begin{array}{l}\text { Certification of compliance } \\
(66 \pm 0.030 \text { in. long } \times 0.398 \pm \\
0.001 \text { in. diameter })\end{array}$ \\
\hline $\begin{array}{l}\text { M. Control Rod } \\
\text { Assembly }\end{array}$ & $\begin{array}{l}\text { 1. Fit-up with fuel } \\
\text { buncle }\end{array}$ & $10-1 b$ drag force $\max$ & Each assembly \\
\hline $\begin{array}{l}\text { N. Control Rod } \\
\text { Assembly } \\
\text { Hardware }\end{array}$ & $\begin{array}{l}\text { The component characteri } \\
\text { pieces. }\end{array}$ & tics will be documented in & the same manner as fuel bundle \\
\hline
\end{tabular}


distribution characteristics, the fuel bundle strength test, the DNB and thermal-mixing test, the control rod drop tests, and the pressure drop test (see Tables III and IV) are also components of the characterization program and demonstrate the emphasis given to fuel module characterization.

\section{FABRICATION}

The fabrication program is based on the quality assurance requirements of RDT Standard F2-2. All manufacturing and inspection operations are performed in accordance with detailed procedures and under facility conditions that assure cleanliness requirements are satisfied. Deviations from approved specifications of components or processes are formally reported and dispositioned by the appropriate technical agencies. The fuel bundle and upper structure fabrication programs at Exxon Nuclear Co. in Richland, Washington, and L\&S Machine Co. in Latrobe, Pennsylvania, have been performed under a policy of full-time EG\&G Idaho Quality Division surveillance and periodic technical audits by EG\&G Idaho, MPR Associates, Inc. (Exxon only), and ERDA (Exxon only). Table IX is a summary list of the fabricators of the fuel module components. The performance of the principal fabricators was exemplary; each demonstrated skill, efficiency, pride in their product and corporate image, and responsiveness to frequent design changes and requests for technical assistance. The success of this fabrication program is indebted to these suppliers. Some interesting information from the fabrication program is as follows.

\subsection{Laser Welding}

This part of the fabrication program is of special interest because of the experience and limited success in performing an extremely difficult welding task. LOFT fuel rods require the welded attachment of fragile thermocouples having a sheath thickness of only 0.009 inch to the fuel rod. Up to four thermocouples are attached over virtually the entire fuel rod length. In some cases this required approximately 5000 weld spots that had to be (a) positioned on the filler wire between the thermocouple and fuel rod cladding within \pm 0.002 inch and (b) identical in size and thermal intensity. The welding equipment includes two identical units each consisting of a basic Korad (Korad Division of Hedron, Inc., Santa Monica, California) laser-driller model KWD which uses a YAG (Yttrium-Aluminum-Garnet) laser rod and a specially designed pneumatically controlled positioning and indexing tool provided by S/P Product Design of Costa Mesa, California.

This laser welding system has been in a continuous improvement status since late 1971. Equipment improvements include:

(1) Shutter positioning

(2) Power supply component shock mounting

(3) Power supply instrumentation

(4) Binocular sight reticle

(5) Optic alignment techniques 


\section{TABLE IX}

LOFT FUEL MODULE FABRICATORS

Component

1. Fuel pellets $\left(\mathrm{UO}_{2}\right)$

2. Fuel rod cladding. $(\mathrm{Zr}-4)$

3. Fuel rods

4. Spacer grids (Inconel)

5. Guide tubes: $S S$

$$
\mathrm{Zr}-4
$$

6. End boxes
Fabricator

Exxon ruclear Co.

Sandril Special Metals Co.

Exxon fluclear Co.

Caran Precision Eng'g Mfg'g Co.

Superior Tube Co.

Sandrik Special Metals Co.

L\&S Machine Co.

Exxon Nuclear Co.

Handy and Harman

Allied Pacific Manufacturing Co.

Exxon Nuslear Co.

Exxon Nu:lear Co.

Duer Soring Co.

L\&S Machine Co.

United Precision Machine Works

EI. Dupont deNemours \& Co.

EG\&G I Jaho, Inc.

Monsanto Research Co.

EG\&G Idaho, . Inc.
Address

Richl and, Washington

Kennewick, Washingtọn

Ricrlanc, Washington

Paramourt, California

Morristciwn, Pennsylvania

Kenriewick, Washington

Latrobe: Pennsylvania

Richland, Washington

New York:, New York

Compton: California

Richliand, Washington

Richland, Washington

Coraapois, Pennsylvania

Latrabe, Pennsylvania

Salt Lake City, Utah

Wilnington, Delaware

Idahc National Engineering Lab.

Daytcn, Ohio

Idahc National Engineering Lab.

18. Fuel Module Assembly 
(6) Flash lamp support

(7) Tooling alignment techniques

(8) Preventive maintenance program

(9) Optical and pneumatic system cleanliness

(10) Laser beam intensity pattern measurement and adjustment techniques

(11) Laser room temperature stability.

The laser system production record is of interest because of an evalution of significant improvement in efficiency. A production record summary is shown.in Table X.

The first core and spares compaign peak production period was preceded by development of techniques for measuring and adjusting the laser spot energy intensity pattern which solved a chronic problem of nonuniformity between the "frontside" and "backside" welds (see Figure 10). The reload core compaign was preceded by several process and equipment improvements designed to increase equipment reliability and reduce operator errors.

The complexity of the operation is very demanding on the operators, and operator errors accounted for approximately $5 \%$ of the rejected rods during the first core and spares production campaign. The system is capable of producing a four-thermocouple fuel rod in approximately 10 hours per machine.

\subsection{Fuel Bundle Assembly}

This activity has also undergone an evolutionary process to achieve the specified alignment objectives. The assembly is accomplished in a horizontal position for instrumentation handling purposes. Fuel bundle alignment objectives were achieved after several technical problems were solved. Some of the highlights are as follows:

(1) The skeleton assembly involves spacer grid attachment to the guide tubes by split rings positioned above and below the spacer grids and welded to the guide tubes. The locking-ring-to-spacer-grid separation was discovered to be important to spacer grid parallelism characteristics, and welding process improvements were required. It was later discovered that shrinkage from the locking-ring-toguide-tube welding also contributed to the spacer grid parallelism, and welding sequence improvements were made.

(2) The upper end box is attached to the guide tubes by mechanical (threaded) techniques. The torquing of the nuts results in residual torque in the guide tubes which causes the free-standing skeleton or fuel bundle to twist. Process improvements were made to minimize residual torque in the guide tubes.

\subsection{Fuel Module Assembly}

The assemhly of the LOFT instrumented fuel modules involves a complcx process consisting of parallel (two fuel modules) assembly processes requiring coordinated, 


\section{TABLE X}

LOFT FUEL RCI THERNOCOUPLE ATTACHMENT HISTORY

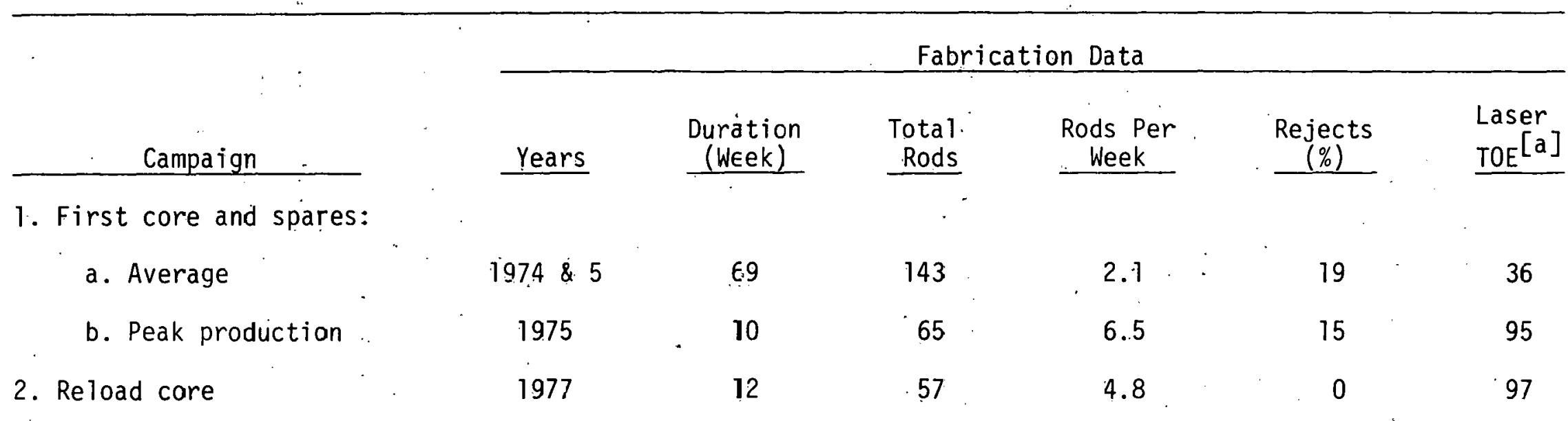

[a] Equipment time-oferating effiçiency. 
sequenced, highly skilled participation by pipe fitters, mechanics, welders, equipment operators, and instrument cable brazing, splicing, and terminating technicians. Errors in the fuel module final assembly stages are especially serious, because the instrumentation is generally not replaceable and the completed instrumented fuel module value is approximately $\$ 500,000$.

A program for management risk appraisal and correction was implemented using the results of the prototype assembly activities, a committee review of facility readiness, and the production activities. Improvements in fuel module quality and reductions in the fuel module assembly time, which were experienced during the assembly campaign, indicate the risk appraisal program was effective. Also fuel module damage was avoided during a flooding incident while the assembly facility was unattended by prior recognition of the risk and implementation of mitigating safeguards.

Technical highlights of the fuel module assembly program include the following:

(1) The brazing and welding process for sealing the instrument cable to the reactor pressure boundary was performed without instrument cable drainage. Special control of component dimensional and cleanliness characteristics likely contributed to process reliability. A technician-developed brazing-process sequence change resulted in an improvement in reproducibility.

(2) The hard-to-soft sheath instrument cable splice reliability and reproducibility was improved by development of (a) a stronger splice design (see Appendix A, Figure A-12 drawing zone -7C) and (b) a method for confirming the correct splice lead matchups (heat splice and measure detector output). The only instrument loss (one thermocouple) occurred at this assembly step.

(3) The development of a technique for confirming the function and location of each thermocouple. The technique consists of applying a focused stream of hot inert gas (argon) to the thermocouple hot junction and measuring the thermocouple output. Several location irregularities were discovered. 


\section{CONCLUSION}

The total program for the design, characterization, and fabrication of the LOFT fuel modules has achieved an objective of technical activity documentation and component characterization in a manner that (a) indicates an effort to provide a fuel module that will credibly represent an LPWR fuel bundle during a LOCA and (b) determines the representative characteristics of the LOFT fuel bundles. The achievement of design objectives and success of the total fuel module design, characterization, and fabrication program will be determined by the performance of the fuel modules in the LOFT testing program. The planning and preparation activities for the interim fuel bundle inspection (requalification) and final fuel bundle examination (posttest autopsy) components of the LOFT testing program are procccding. 
APPENDIX A

LOFT FUEL MODULE ASSEMBLY DRAWINGS 
THIS PAGE

\section{WAS INTENTIONALLY \\ LEFT BLANK}


" 2 WELD PER ASME GCLLER \& PRESSURE VESSE CODE

3) INSTRJMENT LEADS TO BE BRAZEC INTO BUYTON
ASSYS PER ANC BRAZE PROCEDURE BR $1.2-465$ \& 461 .

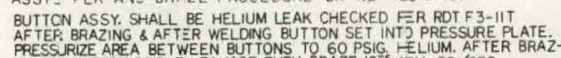

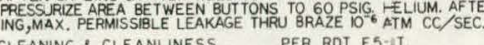

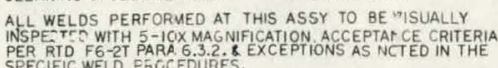

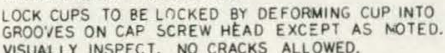

LUBRLATE UNDER HEADS \& ON THREADS OF ALL
THEADED FASTEEERS PER RDT FB-IT WITH 2 COATS OF NEOL JBE B, DAG 155 OR EQ

TORQUUE FASTENERS PER ROT F8.IT TO VALUE SHCWN IN TORQUE
TABLE. TIGHTEN TO INITIAL TORQUE VALUE, REL AX VALUE \& LOCK IN PLACE AS SHOWN OR NOTED. REFFS,

10 MARK PER RDT FT-3T USING VIBRATING MAREING

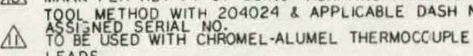

18. TO BE USED WITH PLATINUM-RHODIUM THERMOCOUPLE

13. LEADS. SUPPLED AS PART OF INSTRUMENT BY

A4 INSTRUMENTATON BRANCH. CLASS

(15) THESE PARTS FURNISHED AS LOOSE PIECE ITEMS ON SHOWN IN L/M TO ASSIST IN PROCUREMEN AN FABRICATION ONLY. SEPARATE ORDEFING IS NOT REQD UNLESS PARTS ARE NOT INCI

16. INSTALL FITTING PER VENDOR'S INSTRUCTIONS EXCEPT
TORZUE $1 / 4$ TO I/2 TURN BEYOND FINGER TISHT

10. Welo to be PERformed after final ins allation

OF FASTENER.

19. LIQUID PENETRANT INSPECT PER RDT F3-6T.
ACCEPTANCE CRITERIA PER RDT FE-2T PARA 63.3

-20 Denotes torque requirements. SEe table

3. W-X DENOTES WELD IDENTTFICATION NO.
WEL TO BE PERFORMED IN UPPER .50 INCHES
OF CHANNEL ONLY,

23 CAUTION: WELDS TO BE PERFORMED ALTERNTTELY ON TEMPERATURE BETWEEN WEI OS TO MINIMIIZE
DSTORTION CAUSEO BY WELDING

29. ANY INSTRUMENT WHCH ORIGINATES BELOW PLANE DM-

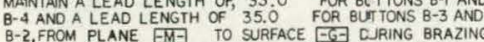
OF BUTTONS, TO INSURE ADEQUATE LEAO LENGTH DURING

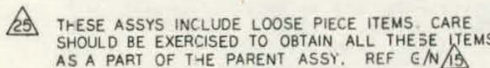

66 Thread Length Shall be 1.12 Min.

20. THIS ASSY MODIFIED BY 204614-I ASSY

28 TO BE USED WITH FLOWMETER COL LEADS.

THESE PARTS ARE NOT INTERCHANGE ABLE AND ARE
TD BE SRRALIZED AND MANTANNED AS, MATCHED

ASSEM SEOUEMCE FOR THE FUEL MOU CAM

30 ASSEMBLY SEQUENCE FOR THE FUEL MOIULE ASS
SHAL BE IN ACEORDANCE WTIH THE APP LABLE
SECTIONS OF THE LOFT FUEL HANDLING MANUAL.

31. DATUM -A- IS DEFINED AS THE VERTICAL REFERENCE
CENTERLINE PASSING THROUGH THE CENTER OF BOUNDARY PLASES F FRMED BY A REGGT TRIANGLE HAVING
2 ADACENT T.55O SIDES. THE CENTER OF THE RIGHI TRIANGLE IS DETERMINED BY THE INTERSECTION OF

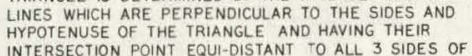
INTERSECCION POINT EQUI-DISTANT TO ALL 3 SIDES OF
THE TRIANGLE. 2 DATUM M-B- 15 DEF FNED AS THE VERTICAL REFERENCE
CENTERLINE PASSING THROUGH THE CENTERS OF THE TRIANGULAR SECTIONS OF THE UPPER SUPPORT
STRUCTURE LOCATING PAD AT STA 278.46 AND THE STRUCTURE LOCATING PAD AT STA 278.46 AND THE
UPPER SUPPORT STIUCTURE LOWER END BOX AT STA
191.82. THE CENTER OF THE TRIANGULAR SECTIONS IS DETERMINED BY THE INTERSECTION OF LINES WHICH
ARE PERPENDICUA AR TO THE SIDES S HYPOTENUSE EACH TRIANGULAR SECTION AND HAVING THERIRITERSECTION
POINT EQUIDISTANT TO ALL 3 SIDES OF THE TRIANGUUA POINT EQUI-DISTANT TO ALL 3 SIDES OF THE TRIANGULA
SECTION.

33 DURING ASSY. HANDLING \& STORAGE OF THE FUEL TOINSURE THAT THE FINAL FUEL MODULE ALGGMENT IS MAINTANED. MODULE ASSY
BE ROTATED BEYOND THE HORIZOLL NOT AND AN ANY FUE INVERTED ATTITUDE

35 THE UPPER SUPPORT STRUCTURE (4) OR $99 \%$ FUEL BY MACCHING THE LOWER END BOX FLANGE
OF (4) OR (9) AND UPPER ENO BOX OF THE FUEL ASSY

36 SPECIAL INSTRUMEETATION ASSY REQUIREMENTS, POREPAATON REOU, PREPARATION REQUIREMENTS SHALL BE
WITH LMP 306 EXCEPT AS NOTED.

3. ASSY TO BE GAGED AFTER INSTALLATION WELLING

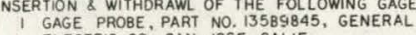

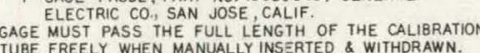

8 DATUM -B. SHALL BE COINCIDENTAL WITH DATUM EA-
DURING ALIGNMENT. REF GN 39 .

39 THE ASSEMBLED ALIGNED FUEL MODULE IN THE VERTICAL

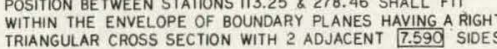
a $c-x$ DENOTES CONNECTOR REFERENCE DESIGNATION

41 DURING ASSY, HANDLLNG, STORAGE \& SHIPPING ACTIVITIES
THE FUEL MODULE, ASSY SHALL NOT BE SUBJECTED THE FUEL MODULE ASSY
TO LOADS GREATER THAN 36 .

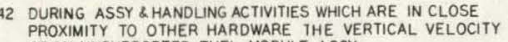
OF AN UNSUPPORTED FUEL MODLLE ASSY
SHALL NOT EXCEED 40 INCHES MINUTE.

43 DURING ASSY \& HANDLING ACTNITTES WHICH ARE IN CLOSE PROXIMITY TO OTRER HARDWARE THE HORIZ
OF AN UNSUPPORED FUEL MODULE ASS
SHALL NOT EXCEED 40 INCHES IMINUTE.

44 RECORDS SHALL BE MAINTAINED FOR EACH FUEL
MOOULE ASSY SO THAT ALARTS PARS SUASSEMBLES

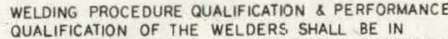
AULLFICATION OF THE WELEERS SHALL BE IN
ACORANEE WTITH ROT FG-2T WITH THE EXCEPTION
OF PARAGRAPH 6.2.1.

A6. HARD TO SOFT CABLE SPLICE JOINTS AND FINAL
CONNECTOR ASSEMBLY SHALL EE MADE IN ACCORDANCE WITH LMP 224 \& LMP 046.

A7 INDIVIDUAL LEAD IDENTIFI I ATION TO BE TRANSFERRED
FOM THE MI CABLE TO TAE POTTING CUP AT THE

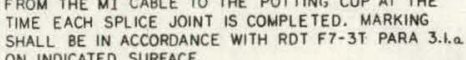

Fig. A-1.
A8 PRIOR TO ASSEMBEY OF THF UPPER SUPPORT STRUCTURE

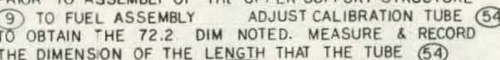
EXTENOS ABDVE SURFACE -JA- THATRING FINAL A5SY OF PRESURE PLATE (5) TO THE TUBE (54) AND PERFORMANCE
OF W-25 MAINTAN THE RECORDED DIMENSION TO INSUE E THE
PROPER POSITION OF THE CALLBRATION TUBE (54) IN THE PEL ASSY

49. THE YOTAL LENGTH OF THE FUEL ASSY AND ONGER THAN THE AS BUILT ENVELOPE DIMENSION (IB6.718) FROM THE BOT TOM SURFACE OF THE UPPER CORE SUPPORT
PLATE ASSY REF DWG 204098 TO THE TOP SURFACE OF THE LOWER CORE SUPPORT STRUCTURE MOUNTING LLATE REF DWG 204065 . THE REQUIRED TOTAL LENGTH
SHALL BE OBTAINED BY MACHINING THE UPPER END OF

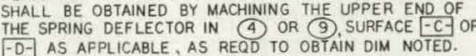

CAUTION: SPRING DEFLECTOR IS TO BE REMOVED FROM
ASSY FOR SUBSEQUENT MACHINING PER AS9. THIS REMCVAL ASSY FOR SUBSEQUENT MACHINING PER A9. THIS REMCVI
SHALL BE PERFORMED BY THE USE OF AN IB-8 SST BOLT 750-10UNC-2AX 24.0 LONG WITH 2.25 MIN CHROME
PLATE THREA LENGH AAD AN 18.8 SST FLAT 67 SPRING TRAVEL FROM THE INSTALLED PRELOAD OF 386-427 L LS. BOLT \& WASHER MAY BE USEE FOR COMPRES SING SPRING \& DEFLECTOR DURRING PG.
OF FLANGE AND DEFLECTOR ONTO HOUSING.

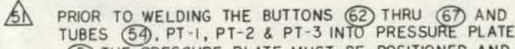

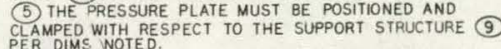

PER DDMS NOTED
PROTECTIVE CLOSURES REQURED FOR ALL TUBING ENDS
PER RRT FT-2T. PLUGS OR CAPS SHALL CONFORM TO PER RDT F7-2T. PLUGS OR CAPS SHALL CONFORM TO
RDT F 7-2T, PARA 6.5. A COPLLEEE LISTING OF PROTECTIVE

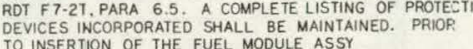
TO INSERTION OF THE FUEL MODULE ASSY
INTO THE REACTOR VESEL AN INVETORY OF THESE
DEVICES SHALL BE MADE TO INSURE THEIR PROPER

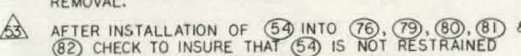
IN2 CHECK TO INSURE TH

54. BUTTONS TO BE VISUALIY INSPECTED AFFER INSTALLATION E BRAZINE OF INSTRUMENT LEADS TO INSURE THAT PRESENCE OF A BRAZE FELLET FORMED AROUND EACH
LEAD AT LOCATON SHOWN.

(55) WHEN 2 OR MORE FASTENERS ARE REOD TO ASSEMBLE

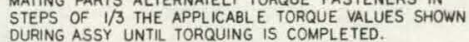

56 B-X DENOTES INSTRUMENTATION BUTTON REFERENCE

7 DATUM KK- IS DEFINED AS THE VERTICAL REFERENCE
PLANE FORMED BY THE EDEE SHOWN OF THE THE TRLANGLAR CROSS SECTTON ON THE UPPER SUPPORT
STRUCTURE LOWER FLANGE LOCATED AT STA III.82.

58 DATUM I-LA IS DEFINED AS THE VERTICAL REFERENCE
CENTERLINE PASSING THROGGH THE CENTERS OF THE UPPER CORE SUPPORT PLATE LOCATING PIN HOLES IN
THE ASSEBLED UPPER FLANGE OE THE UPPER SUPPORT 59. REM IV:D

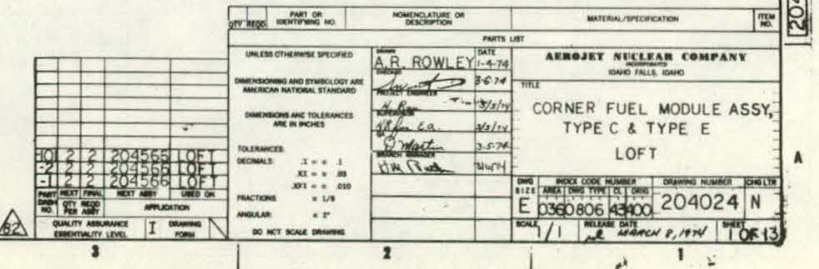

Q THE DIM NOTED SHALL BE OBTANED BY PERFORMING THE AS BUILT DIM FROM THE TOP SURFACE OF REACTOR VESSEL INSTRUMENT
NOZZLES DESIGNATED H.\& P REF DWG 20514 2 SUBTRACT .25O FROM 46.820 .

3 SUBTRACT. 25 FROM THE RESULTANT DIM OF STEP 2. THIS WILL GIVE THE MAXIMUM
ALLOWABLE DIM NOTED ON THIS DWG.

4 IF THE AS BUIT TOTAL DIM NOTED RESULTING
FROM THE ASSY OF (5). (10) \& (17) EXCEEDS THE DIM DETERMINED IN STEP 3, MACHINE
SURFACE TF- TO MAKE DIM NOTED AS RESULT OF ASSY BE WITHMN THE LMIT SPECIFIED IN
STEP 3 PLUS 0.000 MINUS 0.060

61. AFTER MACHINING SPRING DEFLECTOR PER GNA AO FLANGE ONTO THE UPPER SUPPORT STRUCTURE ASSY,

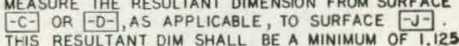
62 INSTRUMENT LEAD ROUTING \& HOOKUP SHALL BE IN
ACCORDANCE WITH LMP 317 FIGI 6. REMOVED

64 PI-X DENOTES PRESSURE TUBE REFERENCE
DESIGNATION.

6S TO BE USED WITH PRESSURE TRANSDUCER LEADS. SLAEW HEAD TO HAVE. O4O DIA HOLE THRU TO ACCOMOOAE

$6 \triangle$ COOLANT TEMPERATURE THERMOCOUPLE TO BE INSTALLED

CA STAKE OR DEFORM CHANNEL DOVE TAIL EDGE ON 12.0
CENTERS TO PREVENT COVER VIBRATION.

69) DURING ASSY \& HANDLING ACTIVITIES SUPPORT SHALL
BE PROVIDED FOR THE INSTRUMENTATION PENETRATION ASSY ABOEE DATUM-G-WHICH MAINTAINS ASSY AND/OR
ANDIVIDUA COMPONENTS WITHIN.I25 OF DIM NOTED

70 OURING ASSY HANDLING S STORAGE WHLLE INA
HORIZONTA POSITION THE FUEL MOOULE ASSY

MUST BE SUPPORTED AT THE FOLLOWING LOCATIONS MAINTANED:

THE UPPER END BOX AT STA 191.82 AND LOWER
END BOX AT STA II3.25 OF THE. FUEL ASSYS.

G/N CONTINUED ON SHT 2 ZONE BH

, TO THE BOT TOM OF THE PINOT ARM SLOT IN
THE CORE BAREL REF STA 293.40 ON DWG
204059 IS 46.820 .
6

I

5

$\uparrow$

4 
NOTES
70 CONTINUED:
2 THEE CENTRALYY LOCATED FUEL SPACER ASSYS
BETWEEN STATTONS 13.25 AND 191.82 .
3 THE LOWER END BOX AT STA 91.82 .

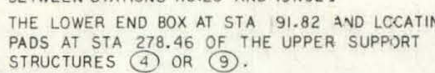
A. REMOVED

12. THIS ASSY MODIFIED BY 206807-1 ASSY RA

IO BO BE USED WITH LLUD
INSTRUMENT LEADS.

- A4. CUSTOM FIT CLIP BY GRINCING LENGTH OF CLIP

WELD THROAT THICKNESS SHALL $8 \equiv .040$ MIN

76 THE ASSIGNED SERIAL Na SHALL CONSIST OF -

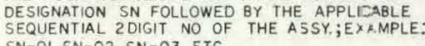

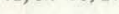

17. CUSTOM FIT CLIP BY REAMING CLP P ID. UNTLL
LEADS ARE A SLIP FIT WITHIN CLIP PRICF TO
WELDING CLIPS TO FUEL ASSY

78. WLL HARD TO SOF SPLLCE JOINTS TO BE MADE
WITHNSPACE NOTED

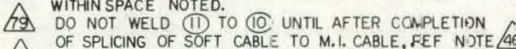

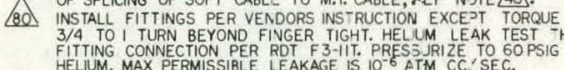

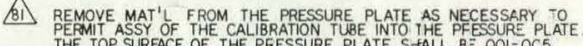

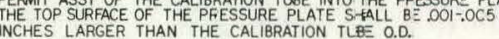

62. REFER TO THE INDIVIDULL COMPONENT DWGS. FOR THE

(33) REMOVED

fod gualti LeVel II

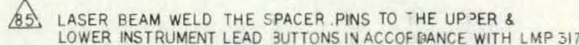
TOTAL RUNOUT BETWEEN THE UPPER G LOWER BUTTON
OUTSIDE DIAMETERS SHALL NOT EXCEED. ODZ AFTER WED DING.

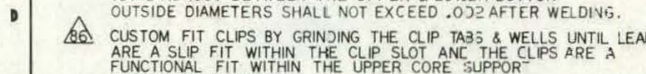
FUNCTIONAL FIT WWTANN THE UPPER CORE SUPPOR
STRUCTURE CHANNEL. 8. THE ANGE OF THE CLPS SHALL CONFOPA TO THE
INSTRUMENT ROUTING AT THE LOCATION NOTEO. 60 MODIFY LENGH OF ITEM 53 TO PERMIT FLUSH FIT WITH GENERAL NOTES CONTINUED ON SHEET 3 ZONE $5 D$

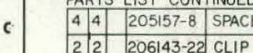

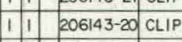
\begin{tabular}{|l|l|l|}
\hline 11 & $206143-18$ CLIP & IITCONE FUBBER RTV 102 \\
\hline 12
\end{tabular} SERAG

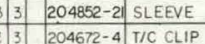
11 204614-32 TUBE CLIP \begin{tabular}{|c|c|c|c|}
\hline 1116 & REMOVED \\
\hline 1 & $206875-1$ & DUMMY FOWMETER \\
\hline
\end{tabular}

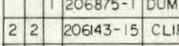
23 2 $206143-11$ CLIP

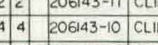
\begin{tabular}{|l|l|l|}
\hline 1515 & $204389-17$ CLIP \\
\hline 15 & 20438925 CLIP \\
\hline
\end{tabular}

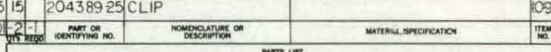
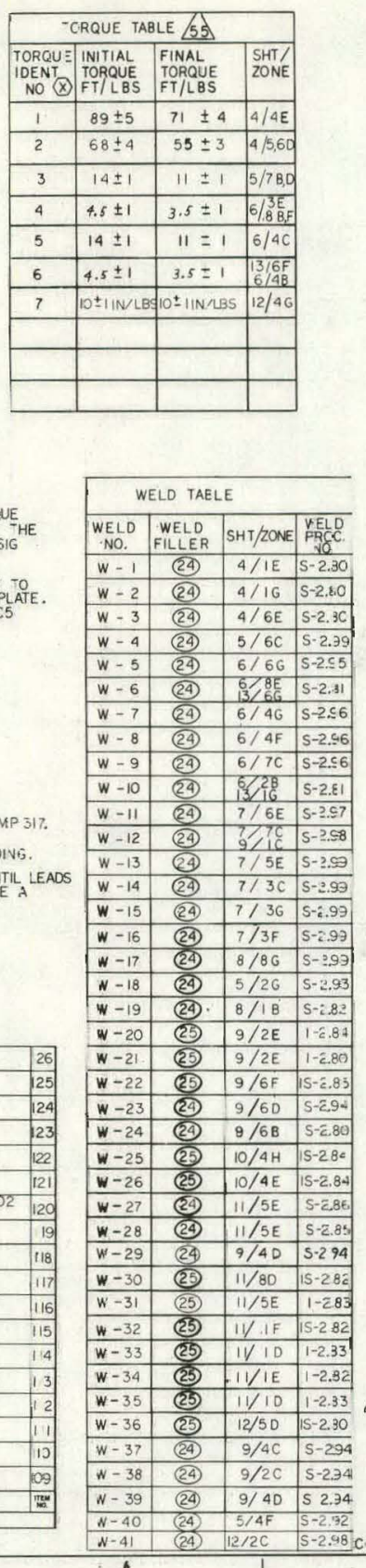

CONTINUEO ZONE A-7 THIS OWG.

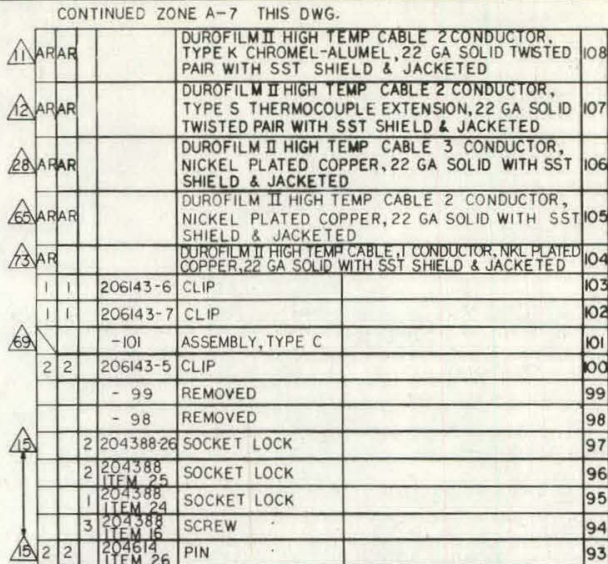

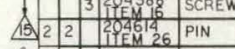

1 1 204-I-316 FERRULE, BACK CERAFFORD FITTING CO.

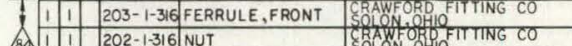

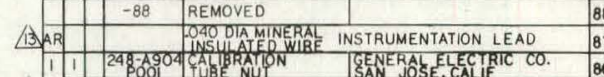

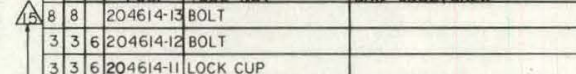

1 .

1. 204614-10BRACKET

\begin{tabular}{|l|l|l|l|}
\hline & 1 & $204614-8$ & BRACKET \\
\hline 5 & 5 & $20164-5$ & TUE GCIP \\
\hline & &
\end{tabular}

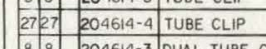

\begin{tabular}{l|l|l|l|l|l|l|}
\hline 8 & 8 & $204614-3$ & DUAL TUBE C \\
\hline 1 & 1 & $204614-31$ \\
\hline
\end{tabular}

\begin{tabular}{l|l|l|l}
3 & 3 & $205157-9$ & SPACER \\
\hline & 1 & $206807-2$ & BPACKEI ASSY
\end{tabular}

\begin{tabular}{|l|l|l}
\hline 1 & XN300,331 FUEL ASSY, TYPE C & EXXON NUCLEAR CO \\
\hline
\end{tabular}

1 205557-1 BUTTON-LOWER

\begin{tabular}{l}
1 \\
$205157-3$ BUT TON-UPPER \\
\hline $206137-37$ BUTTON-LOWER
\end{tabular}

206137-37 BUTTON-LOWER

206137-36 BUTTON-UPPER

206137-16 BUT TON-UPPER

\begin{tabular}{l|l}
7 & $206137-15$ BUTTON-UPPER \\
\hline 1 & $206137-17$ BUT TON-LOWER
\end{tabular}

206137-17 BUT TON-LOWER
$206137-20$ BUT TON-LOWER

\begin{tabular}{l|l}
11 & $206137-19$ BUTTON-UPPER \\
\hline
\end{tabular}

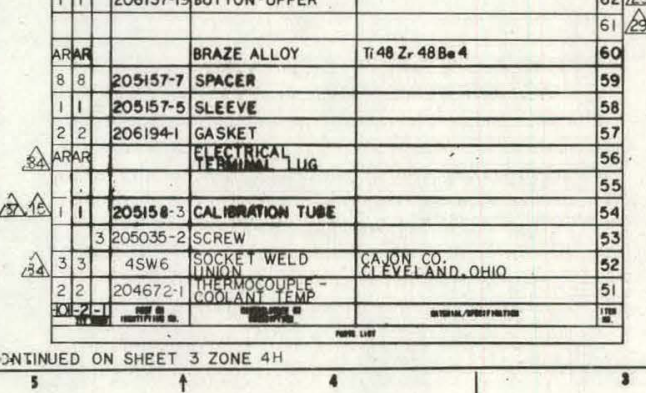

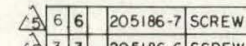

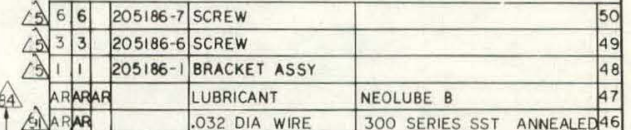

SST ANNEALED

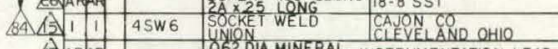

STARAR O NELUA MINERAL INSTRUMENTATION LEAD

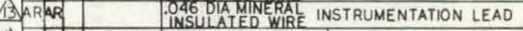

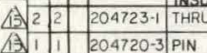

\begin{tabular}{l|l|l|}
\hline 1.1 & $205185-1$ \\
\hline
\end{tabular}

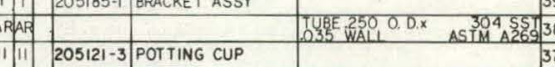

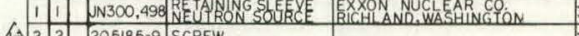

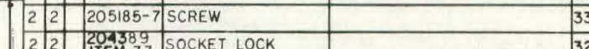

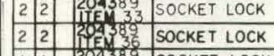

3,205389 SOCKET LOCK

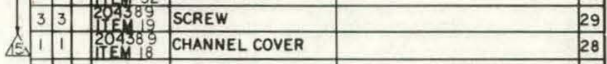

\begin{tabular}{|l|l|l|}
\hline ARAP & & 27 \\
\hline
\end{tabular}

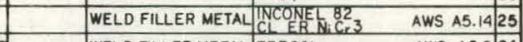

W. 2042 WELD FILLER METAL ER308L AWS A5.924 24

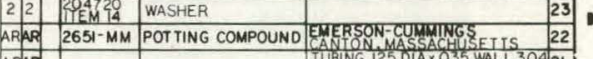

8). Aियनि

\begin{tabular}{lll}
.020 DIA WIRE & 300 SERIES SST \\
\hline
\end{tabular}

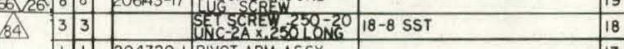

$1004720-1$ PINOT ARM ASST

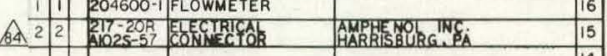

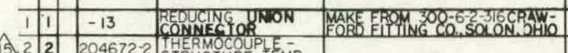

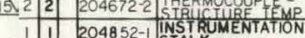

1 204852-1 STAKK

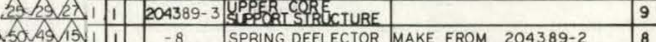
A. A $14-7$ SPANG Def.

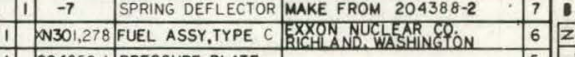

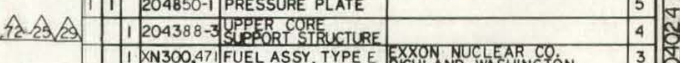

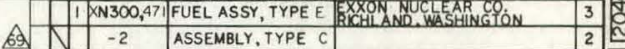

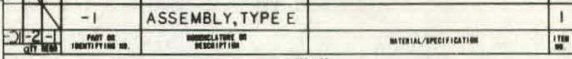

Fig. A-2.

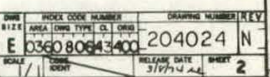

,

1 


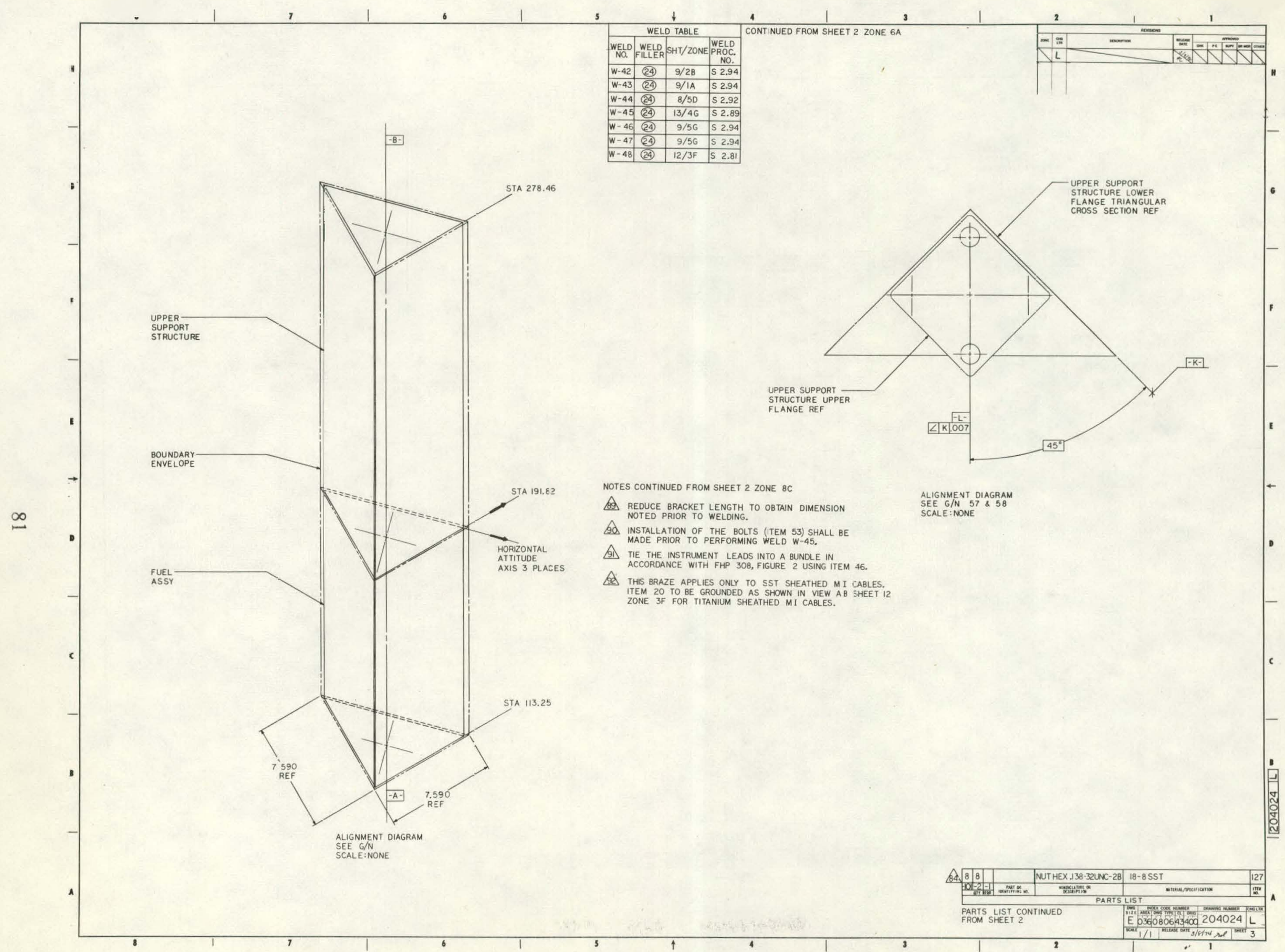

Fig. A-3. 


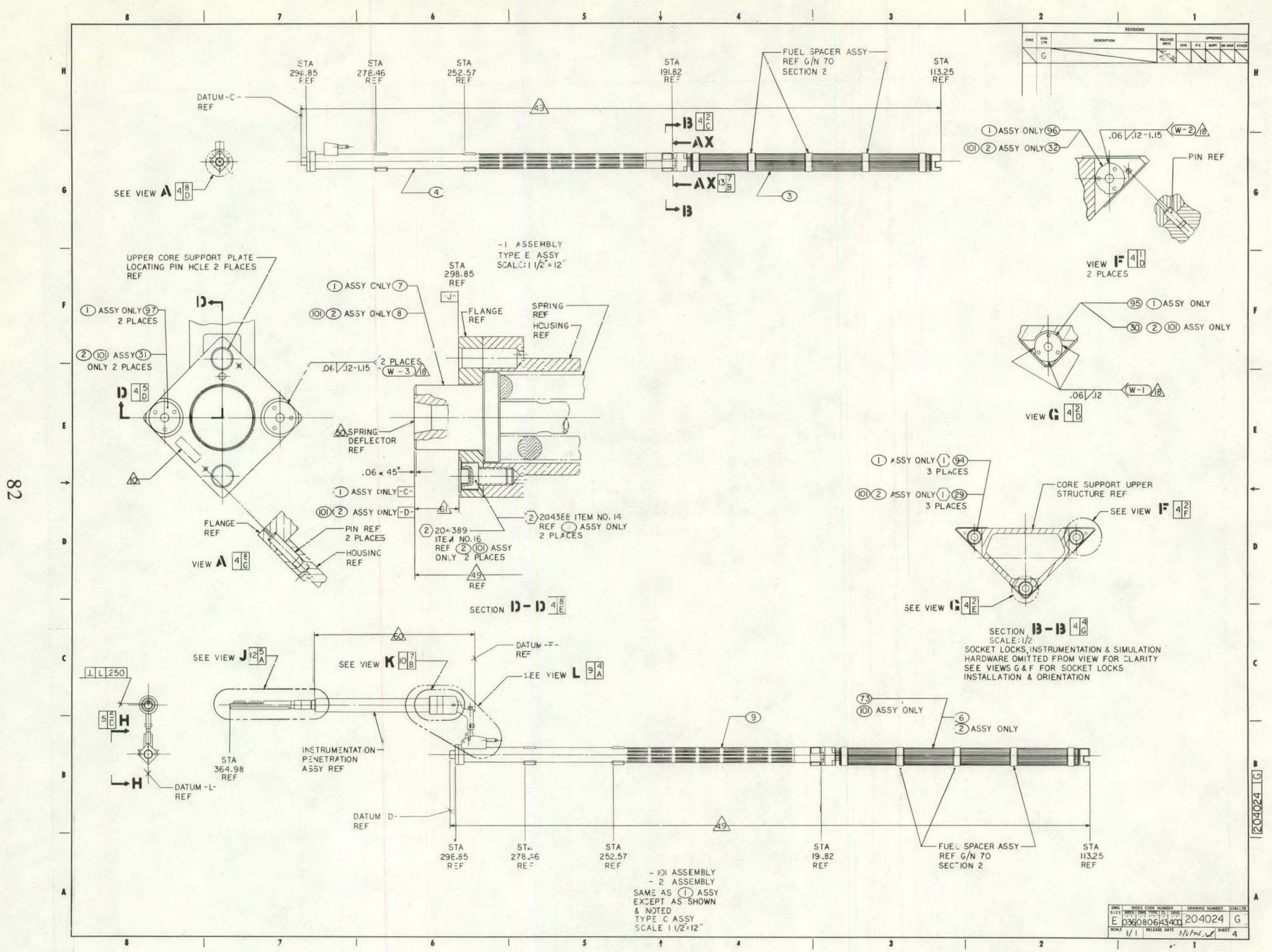

Fig. A-4. 


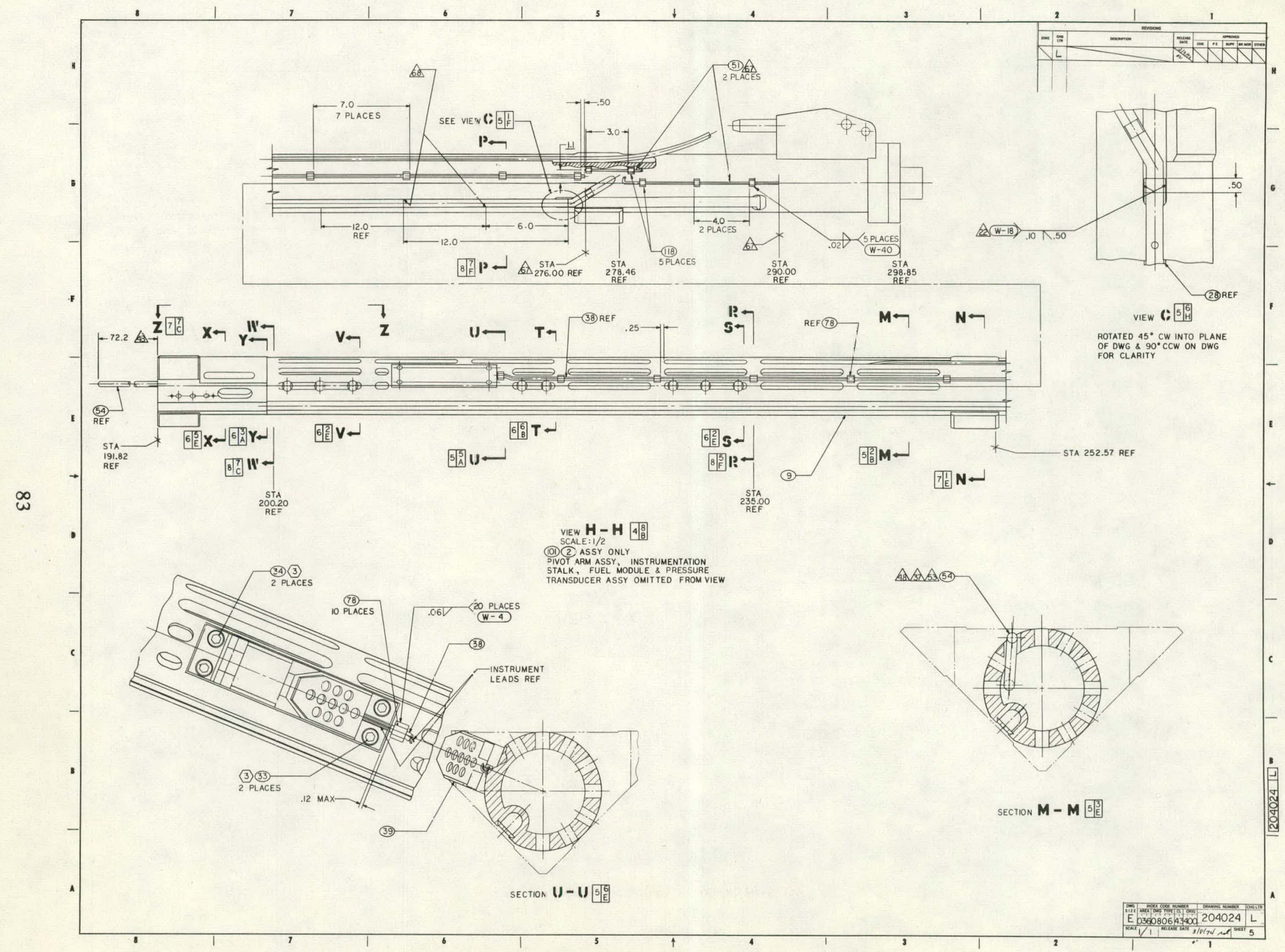

Fig. A-5 


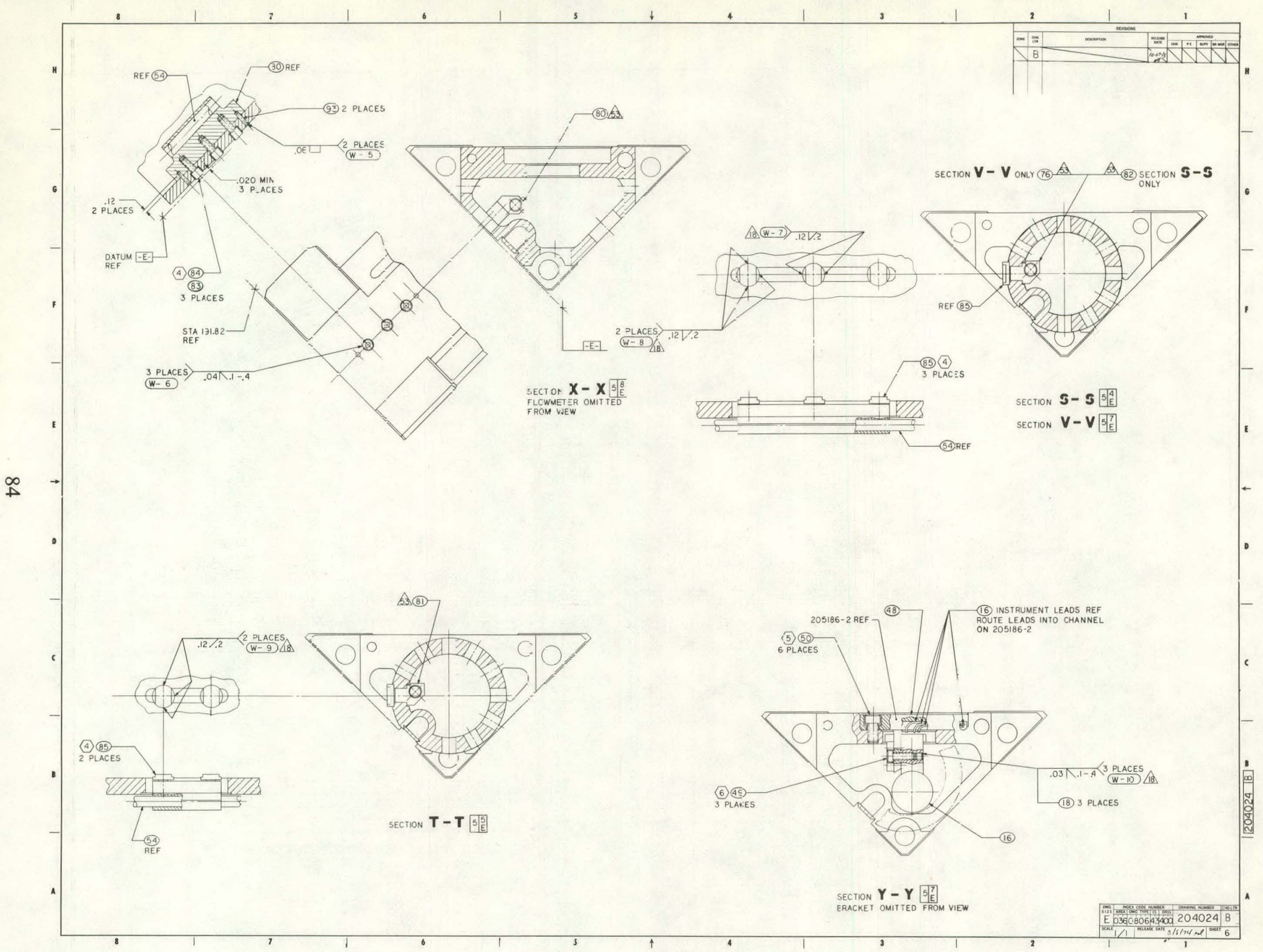

Fig. A-6. 


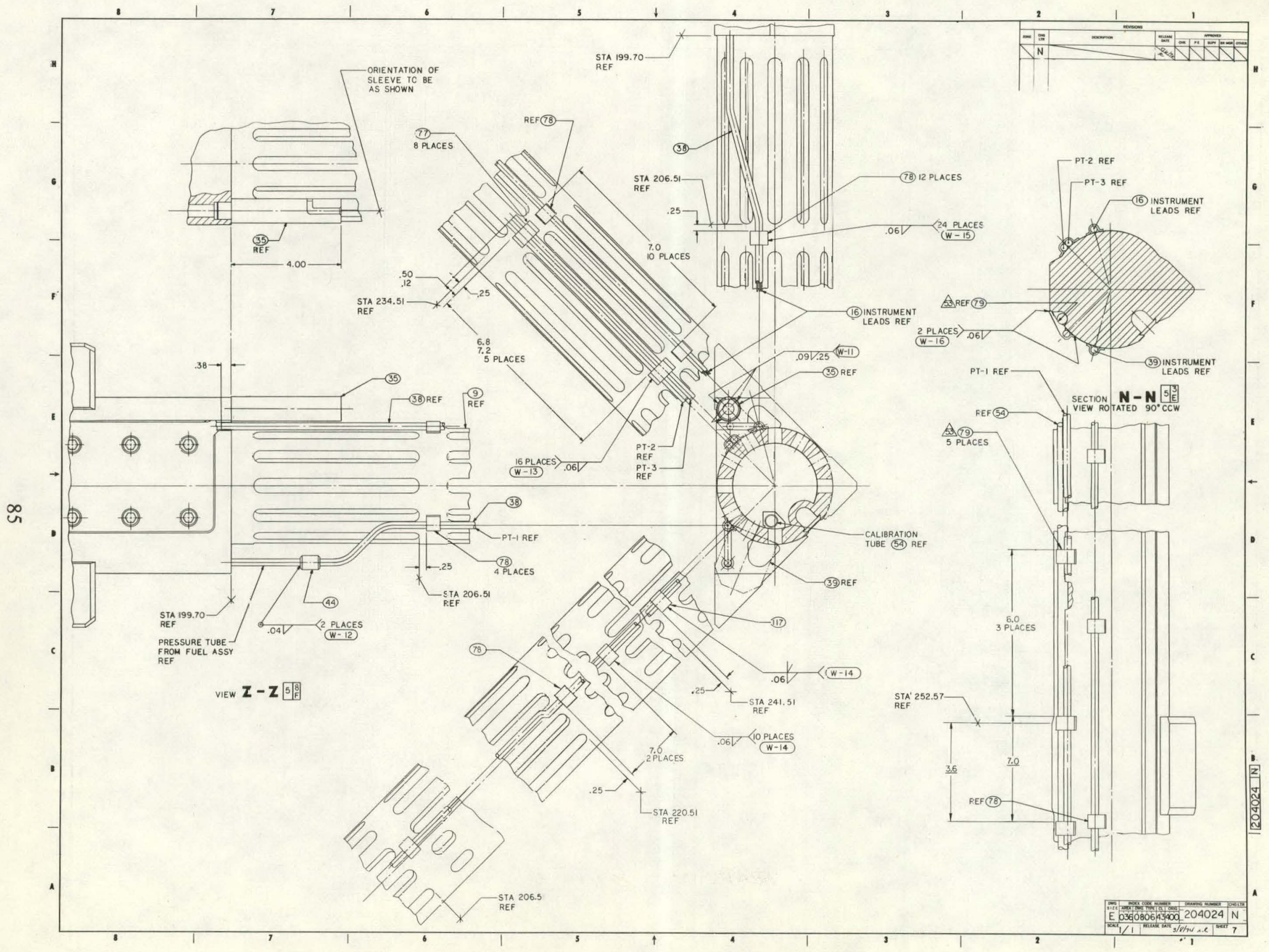

Fig. A-7. 


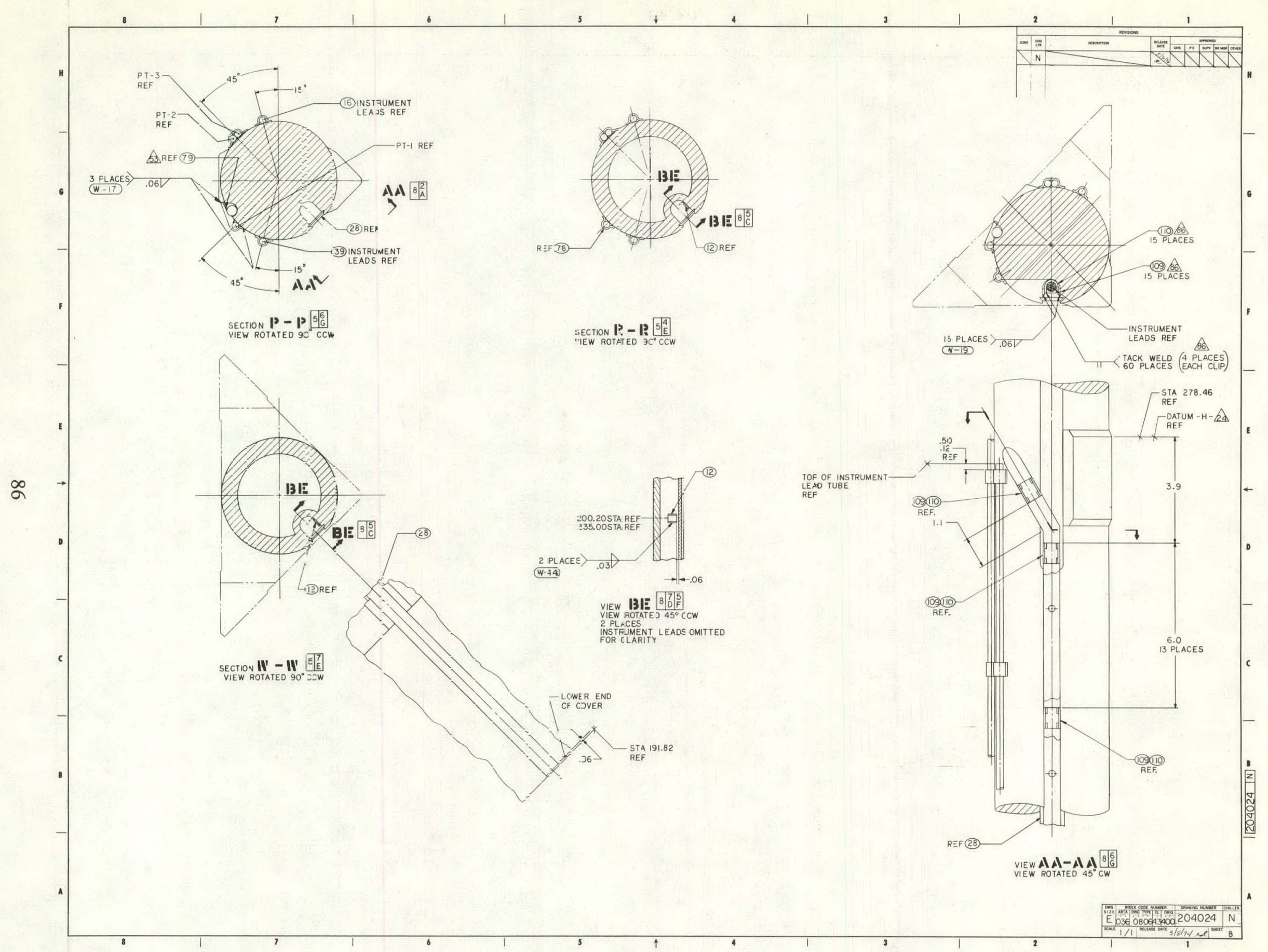

Fig. A-8. 


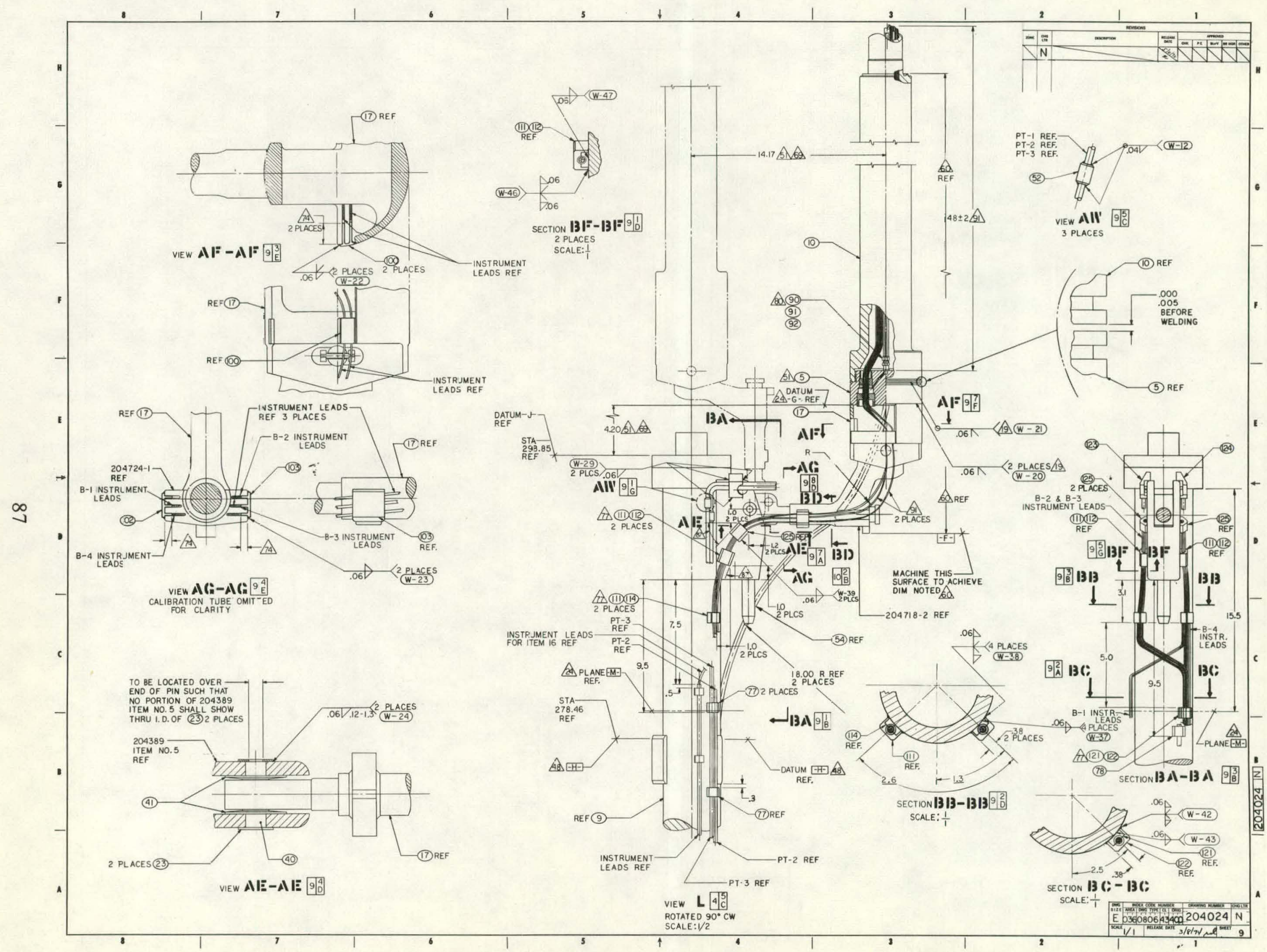

Fig. A-9. 


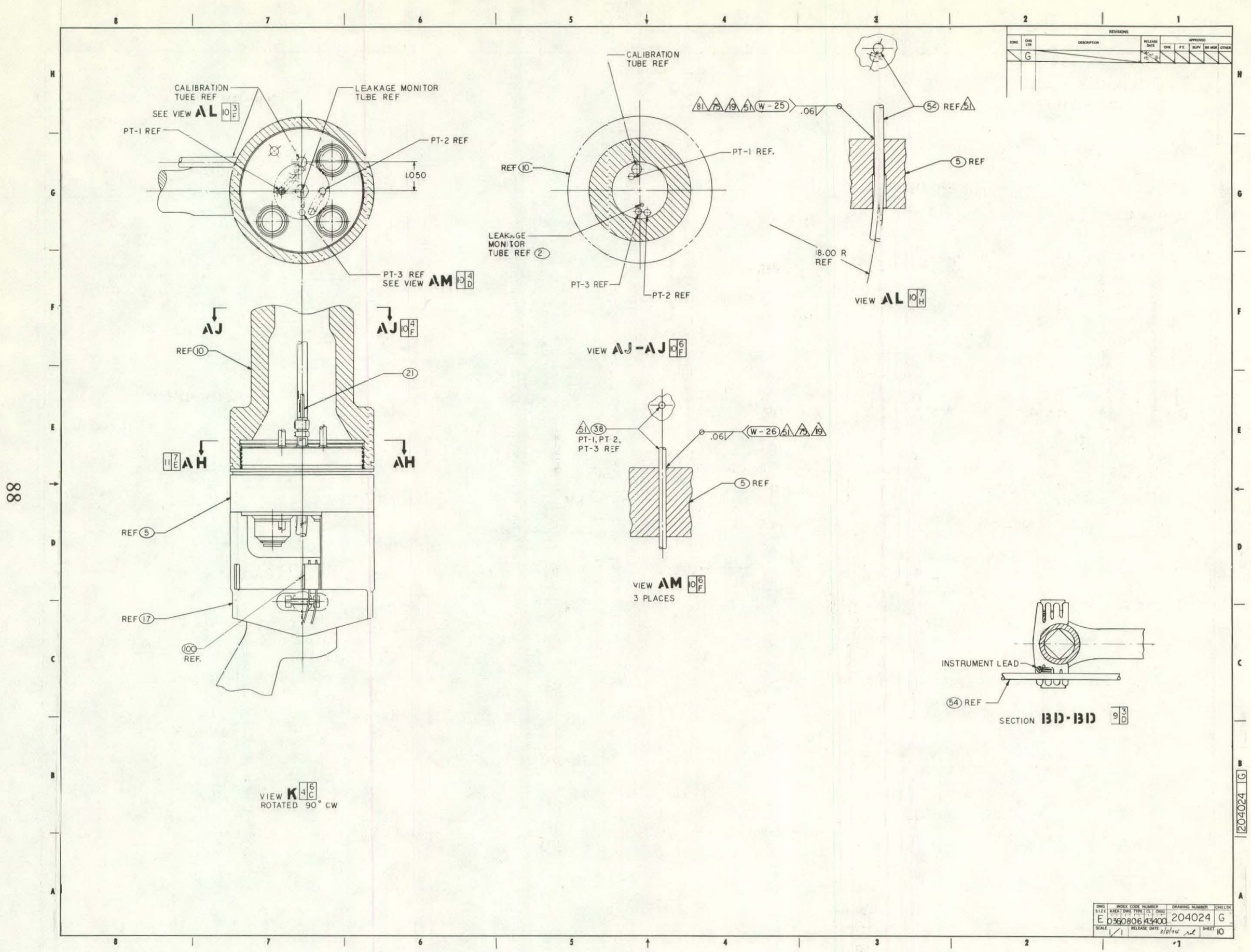

Fig. A-10. 


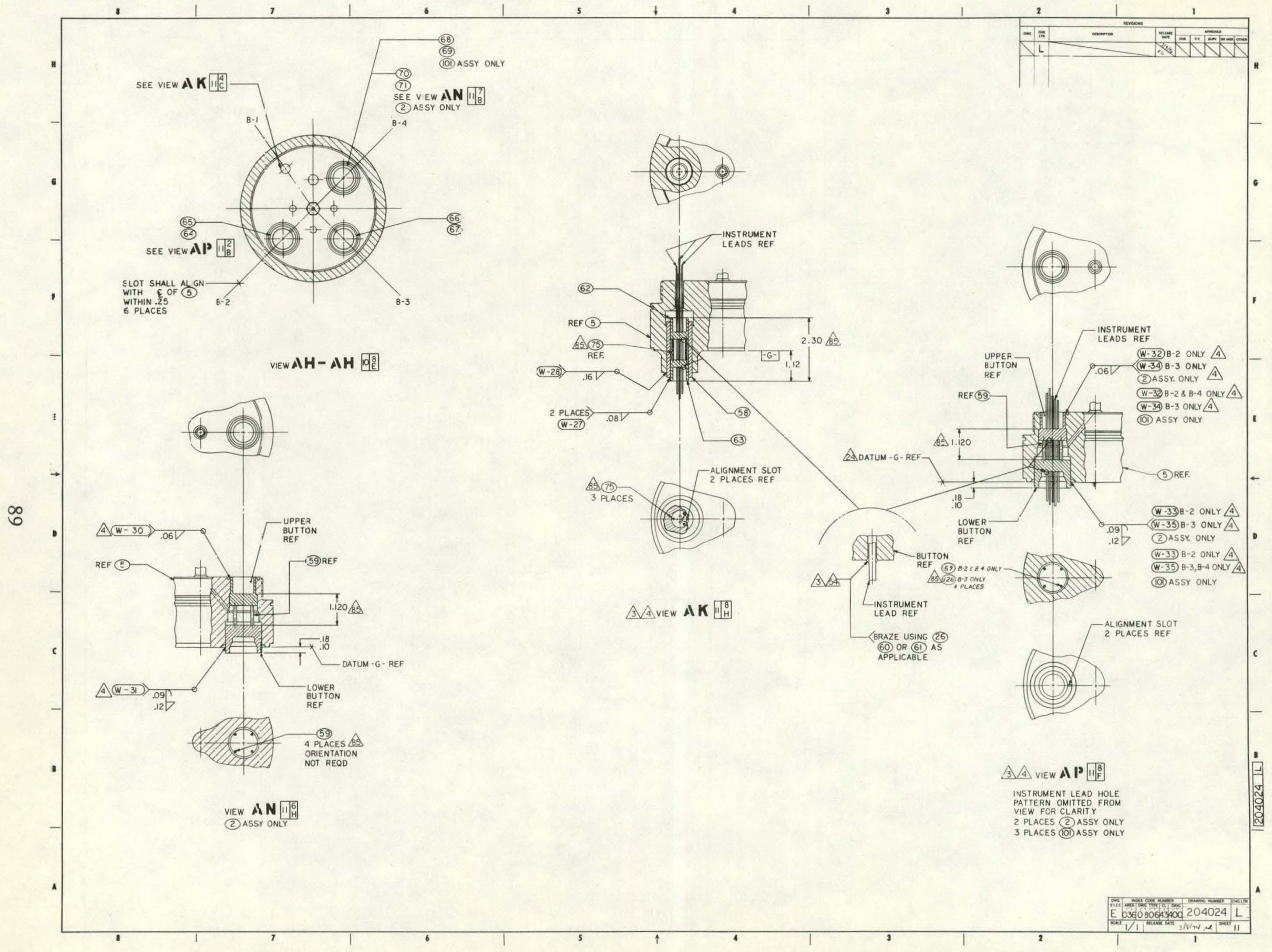

Fig. A-11. 


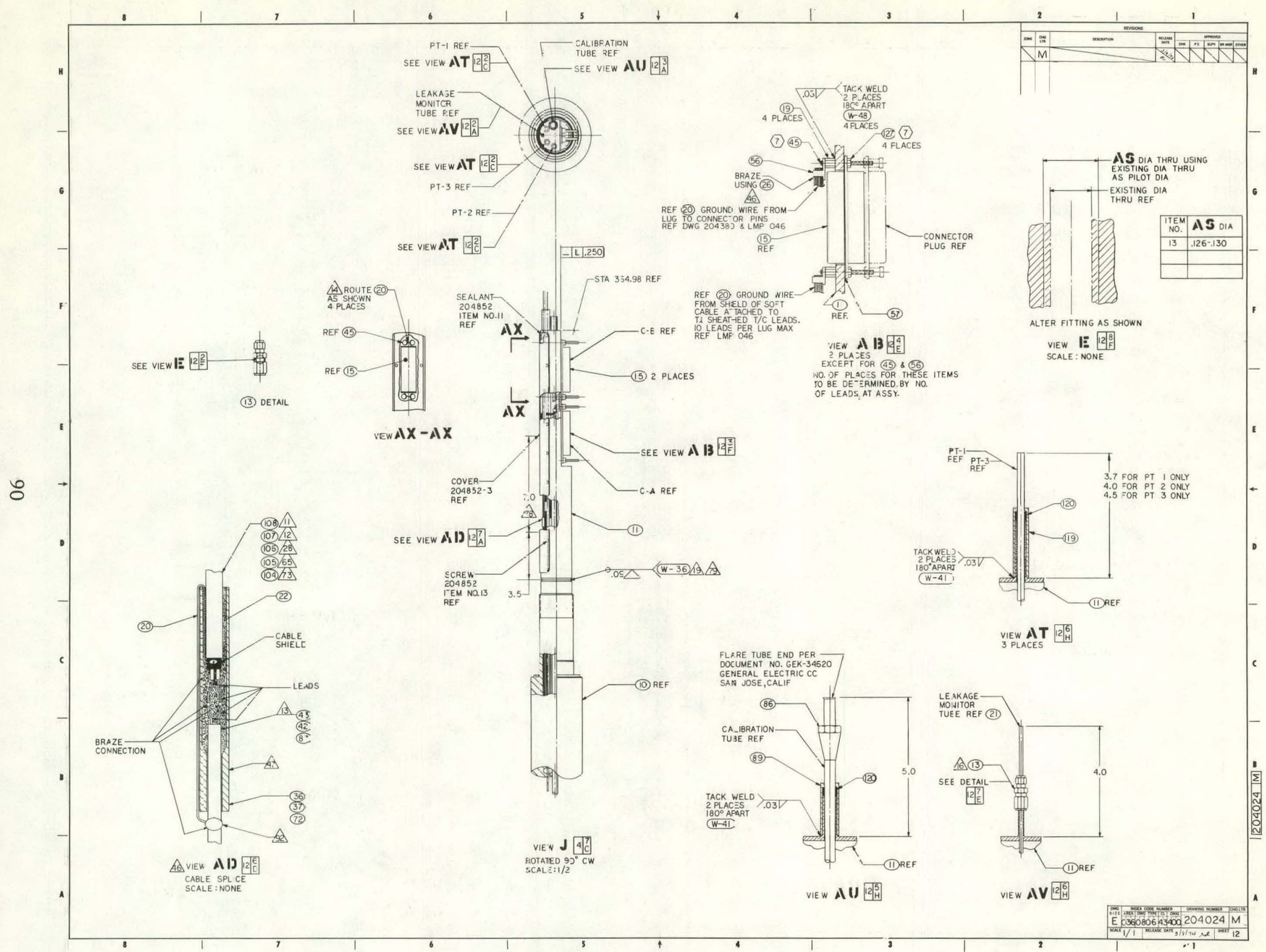

Fig. A-12. 


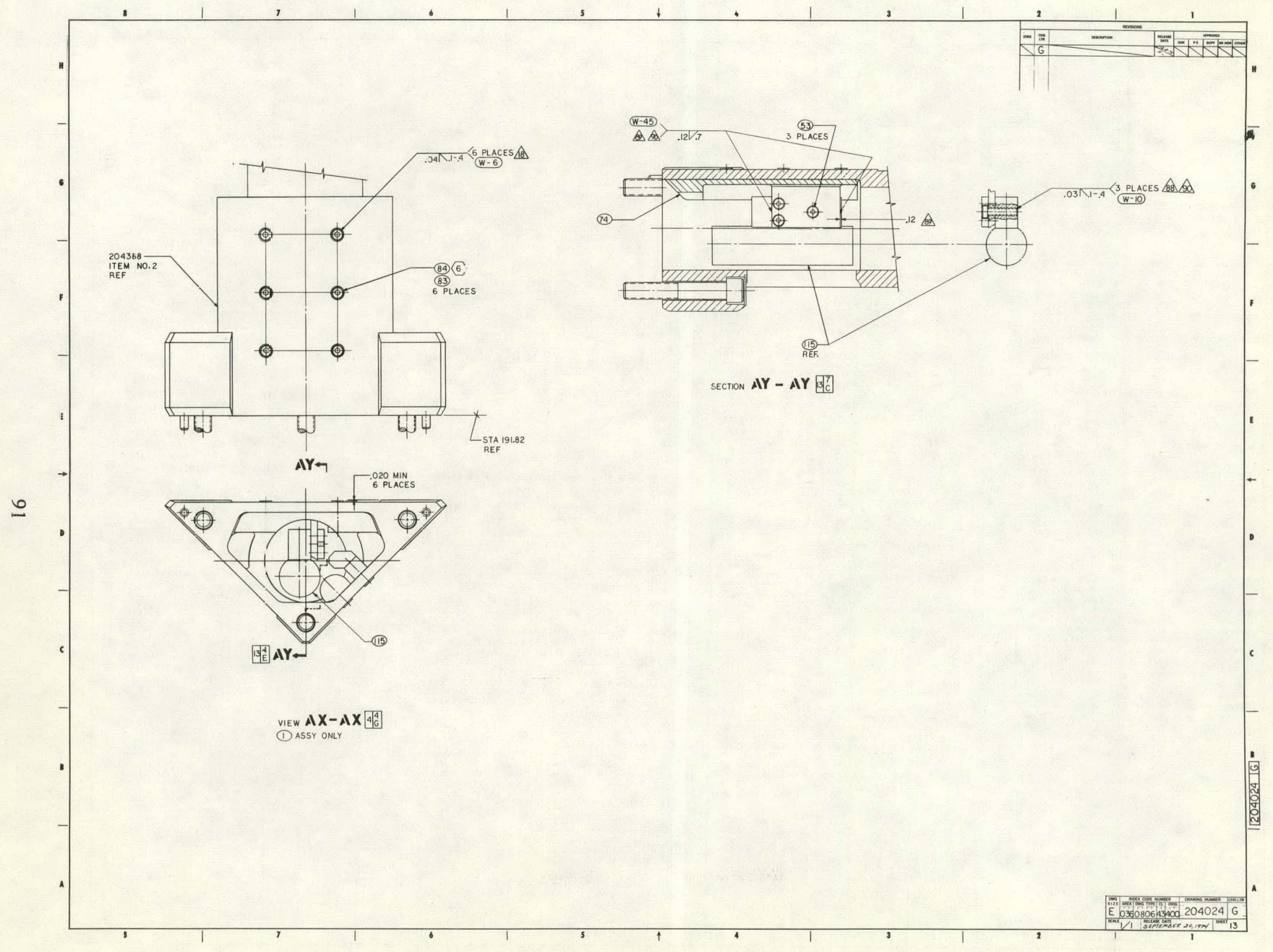

Fig. A-13. 
(1)

1

|

-

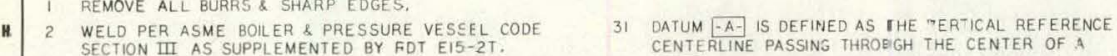

(3) INSTR III AS SUPPLLEMENTED BY FDT E15-2T.

ANC BRAZE PROCEDURE BR I.2 460 OR 461 AS APPLLACALL. 32 DATUM -B- IS DEFIMED AS THE VERTICAL REFERENCE

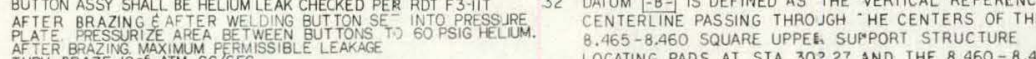

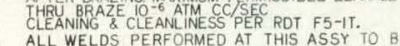

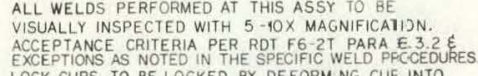
LOCK CPS TO BE LOCED BY DEFRM NG CUF IITO
GROOES ON CAD LCREW HEAD EXCEP AS WTED.
VISUALLY INSPET. NO CRACKS ALLOWED.

B. LUBRICATE UNOER HEADS \& ON THREADS OF A-L
THREADED FASTENERS PER RDT FB-IT WITH 2 COATS

TORQUE FASTENERSS PER RDT F8.IT TO VELUE SHEWN IN TORQUE
TABLE. TIGHTEN TO INITIAL TORQUE VALUE, ZELAX

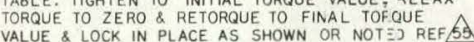

10 MARK PER RDT F7-3T USING VIBRATING

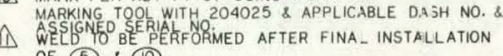

12. TO BE INSTALLED AfTER INSTALLATION OF (5) \& (10)

1. INTO Be SUPPLIED AS PART OF INSTRUMENT BY

13. TO BE SUPPLIED AS PART OF INSTRUMENT
INSTRMETATON BANCH. LOCKWIRE PER RDT MG-2T CLASS B.

44. LOCKWIRE PER RDT MG-2T CLASS B.
C.5 AFTER MOUNTING (12) ONTO UPPER STRUCTUFE ASSY (4) OR (9), HOLD $205188-1$ IN PLACE \& ADJUSTT
$205188-8$ TO OBTAIN DIM NOTED. WELO TO BE MADE AFTER ADJUSTMENT IS COMPLETED. REMOVE 205188-2

6 ReMoved

$$
17 \text { SURFACE ROUGHNESS 125/ UNLESS OTHERWISE NOTED. }
$$

(8) WELD TO BE PERFormed after final installation
OF FASTENER.

19 LIQUID PENETRANT INSPECT PER RDT F3-6T.
ACCEPTANCE CRITERIA PER RDT F6-2T PARA 5.3 .3$.

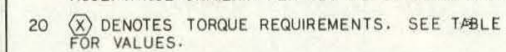

21 (W-X) DENOTES WELD IDENTIFICATION NO.

22 REMOVED

23 REMOVED

c 24. ANY INSTRUMENT WHICH ORIGINATES BELOW SLFFACE

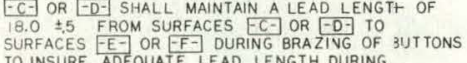
SURFACES FET OR FFA DURING BRAZIIG OF 3 GUT TONS
TO INUSERE ADEQUATE LEAD LENGTH DURING
FINA ASSY.

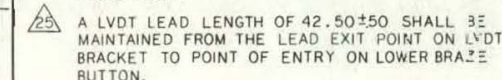

- 26 Removed

28. THIS ASSY MODIFIED BY 204613-1 ASSY

208 THIS ASSY MODIFIED BY 204613-15 ASSY

29. THESE PARTS ARE NOT INTERCHANGEAELE AND ARE

ASSEMBLY SEQUENCE FOR THE FUEL MODULE ASSY
SHALL BE IN ACCORDANCE WITH FUEL HANOLING
PROCEDURE FHP 302 .

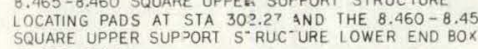

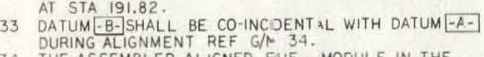
VERTICAL POSITION SHALL IT KITHIN THE ENVELOP OF PARALLEL BOUNDARY PL ANES HAVING AN 8.590$]$
SQUARE CROSS SECTION. 35 REMOVED

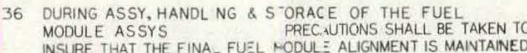
INSURT THAT THE FINA_ FUEL RODUL: ALLGNMENT IS MAINTA
CAUTON: THE FUEL ASSY FND/CR FUEL MODULE ASSY AST AST SHAL HOT AT ANY TME
BE ROATED BEYOND THE HORIZONTA. ATTITUDE - O
AN INVERTED ATTITUDE

3) THE UPPER SUPPORT STRUETLR: (9) OR (9) \& FUEL

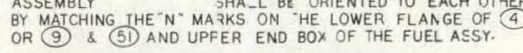

39 SPECIAL INSTRUMENTATION ASSYY REQUIREMENTS,

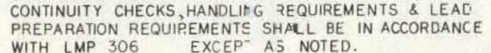

AQ ASSY TO BE GAGED AFTER INSTA LATION \& WELDING QY
INSERTION \& WITHDRAWL OF THE EOLLOWING GAGE :

GAGE PROBE, PAAT NC. 13539845 , GENERAL
ELECTRIC CO., SAN JOJE, C9LIF.

GAGE MUST PASS THE FUL- LEMGTH OF THE CALIBRATION
TUBE FREELY WHEN MANUALLY INSERTED \& WITHDRAWN.

DUAING ASSY, HANDLING STCZAGE \& SHIPPING ACTINTIES
THE FUEL MODU.E ASS SHELL NOT BE SUBJECTED TO LOADS GREATER THAN : G.

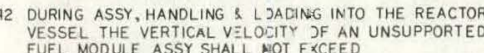

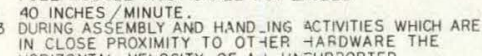

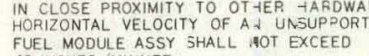
40 INCHES / MINU

44 MARK PER RDT F7-3T USING REMJVABLE TAG WITH
$204025 \&$ APPLICABLE DASE NJ.

45 WELDING PROCEDURE QUALIF EATION \& PERFORMANCE

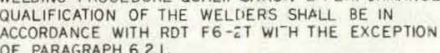

A6 HARD TO SOFT CABLE SPLICE JCINTS AND FINAL
CONNECTOR ASSEMBLY SHAL BE MADE IN ACCORDANCE

4. INDIVIDUAL LEAD IDENTIFICA ION JO BE TRANGFERED
FROM THE MI CABLE TO THE POBETINIS CUP IN FROOROANCE WITH ITP 224 .

AS. PRIOR TO ASSEMELY OF THE UPPER SUPPORT STRUCTURE

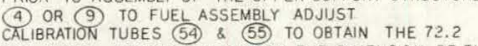
DIM NOTED. MEASURE \& RECORD THE DIMENSION JF TH LENGTH THAT THE TUBES (59) \& (5) EXTEND ABO/E
SURFACES T-C. OR T-D. AS APPLITABLE. DURING FINA AST OF PRESSURE PLATE (5) TO TALES (59) \& 55 \& 8
PERFORMANCE OF WELO W-3 NAINTAN THIS RECORDED DRENSAN TO INSURE THE PROPER POSITION OF TTE
DAMLIBRATION TUBES (59) \& (55) IN THE FUEL MODULE

Asst.

49. THE TOTAL LENGTH OF THE FUEL ASSY AND
UPPER SUPPORT STRUCTURE (4. SHALA BE

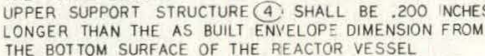
THE BOT TOM SURFACE OF THE REACTOR VESSEL
GLOSURE HEA REF DW $794-E-O 62$ CE NEWING TON, N.H. TO THE TOP SURFACE OF THE LOWE 204065. SUPORT STEQCUTURE MOUTHNG PLATE REF DWG OBTAINED BY MACHINING THE LONER END REF SURFACE

50. THE TOTAL LENGTH OF THE FUE ASSY AND
UPPER SUPPORT STRUCTURE (9) SHALL BE OBTAINED JPPER SUPPORT STRUCTURE (9) SHALL BE OBTAINED
BY PERFORMING THE FOLLOWING: 1 REMOVE SHIM (8) FROM ASSY (9).
2 PROEEED IN THE SAME MANNER NOTED IN A9, EXCEPT REF SURFACE E-DA AND OMIT SHIM 8
THICKNESS WHEN DETERMINING THE LENGTH TO MACHINE (7). (8) INTO (9) ASSY AFTER MACHINING. 51. PRIOR TO WELDING THE BUTTONS (62) THRU (75) AND
TUBES (5) 8 (5) INTO PRESSURE PLATE (5) THE PRESSURE PLATE MUST BE POSITIONEC AND LLAMPED
WTH RESECT TO THE SUPPORT STRUCTURE (4) OR (9)
AS FOLOWS. AFTER MACHINING (7) PER AQ OR OQ MEASURE

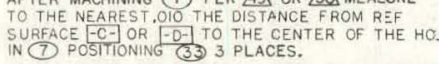
2 TO DETERMINE THE DIMENSION FROM REF SURFACE
-CE OR LD- TO THE BOT OM SURFACE OF 5 (5)
REF $204844-2$ SUBTRACT. 750 FROM THIS MEASURED DIMENSION.
AUTTOON: CHEK CENERLNENATATION OF (5) PRESSURE PLATE PRIOR TO WELDING TO INSURE THAT
IT ALIGNS WITH THE CENTERLINE OF THE (4) OR (9)
UPPER SUPPORT STRUCTURE WIT-IIN .062.

52 C-X DENOTES CONNECTOR REFERENCE DESIGNATION.

DESIGNATION.
DSTRUMENTATION BUTTON REFERENCE

59. BUTTONS TO BE VISUALYY INSPECTED AFTE INSTALLATIO
\& BRAZING OF INSTRUMENT IEADS TO INSURE THAT

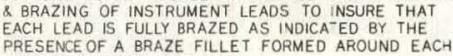
ENCE OF A BRAZE FILLLE
AT LOCATION SHOWN.

55. WHEN 2 OR MORE FASTENERS AFE REQD TO AS SEMBLE

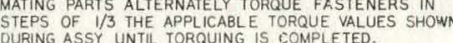

Af ACCEPTABLE SUBSTITUTE FOR 206/44-I IS 206/44-3.

5X BRACKET SHALL BE POSITONEO ON (5) SO THAT NO
PORTION OF BRACKET OR ATTACHING WELOS SHALL

S8) AFTER INSTALLATION OF BO CHECK TO INSURE THAT ATTITDE.

59) TO BE USED WITH CHROMEL-ALUMEL THERMOCOUPLE LEADS OC TO BE USED WITH PLATINUM-RHODINM TIERMOCOUPLE LEAD. SO BE USED WITH LVDT INSTR CIMEVT LEADS.

63 PRRTECTIVE CLLSURES REQUIRED FOR ALL TUBING ENDS
PER RDT F7-2T. PLUGS OR CAPS SHALL CONFORM TO RDT F7-2T. PAAA 6.5. A COMPLETE
LISTING OF PROTECTIVE DEVICES INCORPOARTED SHAL BEEMANAANED.
PRIOR TO INSERTION OF THE FUEL.

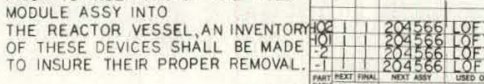

A

64 RECORDS SHALL BE MAINTANNED FOR EACH FUEL
MODULE ASSY SO THAT ALL PARTS \& SUBASEMBLES CAN BE TRACEABLE TO FABRICATION \& SOURCE LOT.

60. INSTALL FITING PER VENDOR'S INSTRUCTIONS EXCEPT
TOROUE I/A TO I/2 TURN EEYOND FINGER TIGH.

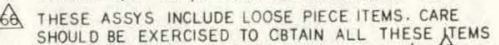

A THESE PARTS FURNISHED AS LOOSE PIECE ITEMS ON AND ARE SHOWN IN LM TO ASSIST IN PROCUREUENT

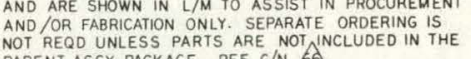

PARENT ASSY PACKAGE, REF G/N 60 .

.

69 REMOVED

Aि SCREW HEAD TO HAVE. O4O D A HOLE THRU TO ACCCMOOATE

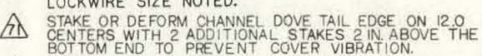

2018 2058 -8 MAY BE MACHINED IN ORDER TO ADJUST AND

3 DURING ASSY \& HANDLING ACTIVTIES SUPPORT SHALL
BE PROVIDED FOR THE INSTFUMENTATION PENETRATION

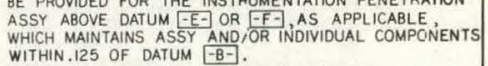

74 DURING ASSY, HANOLING S STOPAGE WHILE IN A
HORIZONTAL POSITION THE FUEL MODULE ASSYS. MUST BE SUPPORTED AT THE FOLLOWING LOCATICN
SUCH THAT THE FUEL MODULE ALIGNEENT IS SUCH THAT

THE UPPER END BOX AT STA 191.82 AND LOWER
END BOX AT STA II3.25 OF THE FUEL ASSYS.

2 THE 3 CENTRALLY LOCATED FUEL SPACER A.SSYS
BETWEEN STATIONS 113.25 AND 191.82 .

3 THE LOWER END BOX AT STA 19182 AND LOCATING
PADS AT SA 302.27 OF HHE UPPER SUPPOFT

13. DESIGNATED STATION APPLIES ONLY PRIOR TO
INSTALLATION OF THE FUEL MOOULE ASSY INTO THE REACTOR VESSEL AND THE VALUE SHOWN WILL BE
DECREASED BY.200 WHEN SUBSEQUENTLY INSTALLED

OA 2 -2 CONDUCTOR HIGH IEMP CABLES, NICKEL PLATED

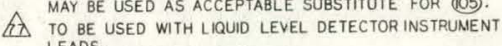
NOTES CONTINUED ON SHT 2
SHT 2 FOR IIST OF MATERIA

SEE SHT 2 FOR LIST OF MATERIAL

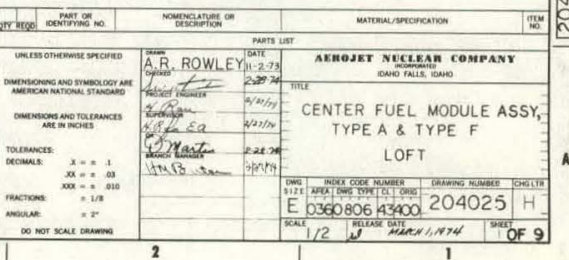




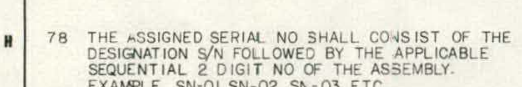

69) WELL THROAT THICKNESS SHALL BE .04O MIN.

99 WELL THROAT THICKNESS SHALL BE .040 MIN.
60 ALL AARO TO SOF FPLICE JOINTS TO BE MADE
WITHN THIS SPACE.

B. DO NDT WELD II TO (O) UNTIL AFTER COMPETION
OF SLLCING OF SOFT CABLE TO MI CABLE, REF
NOTE GE

GO INSTALL FITTING PER VENDORS INS-RUCTIONS
EXCEPT TORQUE $3 / 4$ TOI TURN BEYOND FINGER

13. THE SIZE OF THIS WELD MUST NOT EXCEED.09,

QA REFER TO THE INDIVIDUAL COMPONENT DRAWINGS
FOR THE APPLICAB.E QUALITY LEVEL.

6 Q Qualitr LEVEL II

6. LAzER BEAM WELO THE spacer PINS tO THE UPPER AND LOWER LEAD EUTTONS IN ACC JRDANCE WITH LMP 317. TOTAL RUVOUT BET WEEN THE UPPER ANO
LOWER. BUTTON OUTSIDE DIAMETERS SHALL NOT

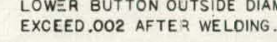

6D CUS-OM FIT CLIPS OTEMS IIO AND II) BY GRINDING THE CLIP TABS ANO WELLS UNTIL LEADS ARE ARE A SLI FIT WITHIN THE CLP ASSY AND THE CLIPS ARE A
FUNCTIONAL FIT WITHIN THE UPPER COPE SUPPOO FUNCTIONAL FIT WITS
STRUCTURE CHANNEL,

60) CUS-OM FIT CLIP INTO MATING PART UNTLL LEADS ARE

19. THIS BRAZE JOINT APPLIES ONLY TO SST SHEATH MI CABLIS.

ITEM 20 TO BE GROUNDED AS SHOWN IN VIEW R, SHT ?

6d CUSTOM FIT CALIBRATION TUBE INTO PRESSURE PLATE
REAMING PRESSURE PLATE. OOI-.005 INCHES LARGER

$\rightarrow$ 61) THE AS LUILT DIMENSION FROM THE TOP OF THE "K. SEAL OF THE SLOTS IN THE PRESSURE PLATE, IEEM 5 (REE SHT. 4, ZONE 4-E) SHAE BE LEST THAN THE AS BULT DIMENSION FROM
THE TOP OF THE SLEEVE, ITEM 7 TO THE CENIER OF THE

THE UPPER COPE SUFPOON TUBES, TTEMS 54 \& 55 TO 1204613-23) BY REAMNG THE. 575/585, DIA. CBORE IREF TO .010 INTEPEREENGE FIT WITH THE CALERATION TURE TE.OTERING SPRRG IREF OWG 20558 ITEM 5 )

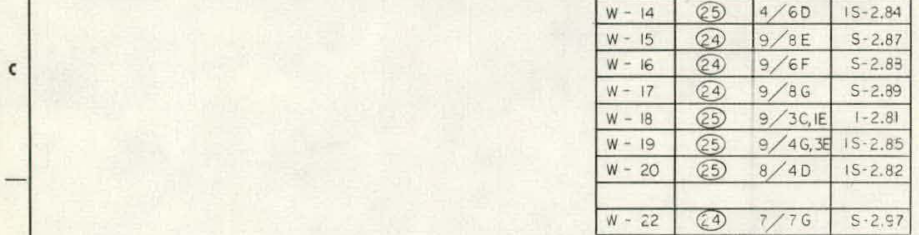

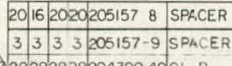

$28282828204390.48 \mathrm{CL}$

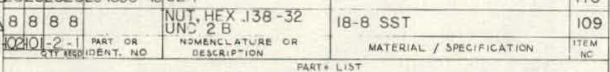
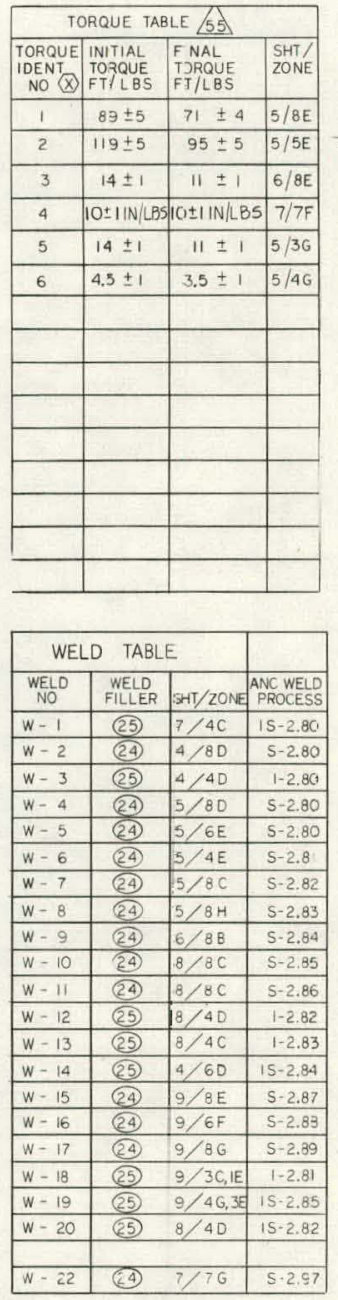

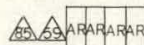

UROFILMI HIGH TEMP CABLE 2CONDUCTOR.

(45) An ARARARAR

6sonstionararar

6s vitrarar

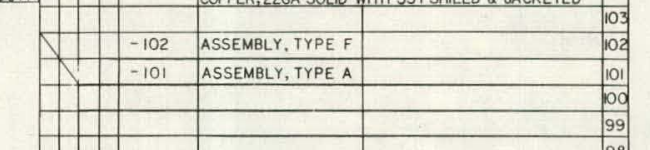

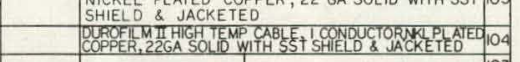

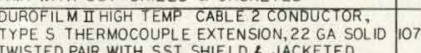
DUROFILM I HIGH TEMP CABLE 3 CONDUCTOR, SHIELO \& JACKETED

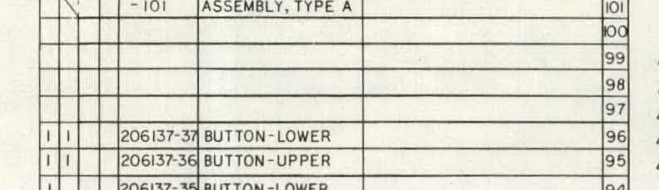

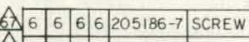

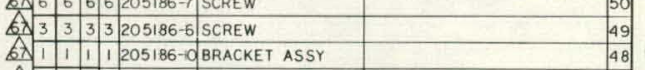

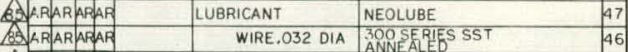

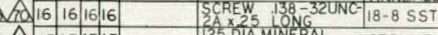

UMENTATION LEAD

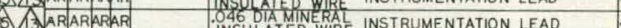

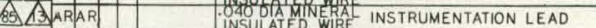

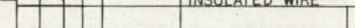

1 206137-34 BUTTON-UPPER

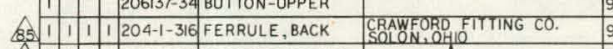

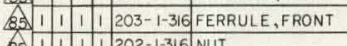

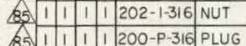
CRAWFORD FITTING CO.

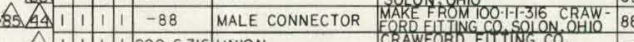

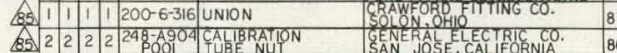

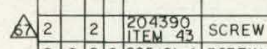

\begin{tabular}{l|lllll}
\hline 2 & 2 & 2 & 2 & 205 & $2121-4$ \\
\hline 24 & POT TING CUP
\end{tabular}

76769676 205 21-2 POT TING CUP

1919 205121-5 POTTING CUP

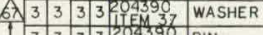

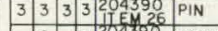

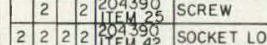

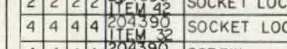

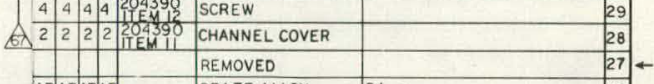

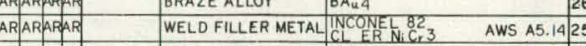

$\begin{array}{lll}\text { ARAARARARE } & \text { WELD FILLER METAL ER3OBL } & \text { AWS A5.14 } \\ \text { ARS A5.9 }\end{array}$

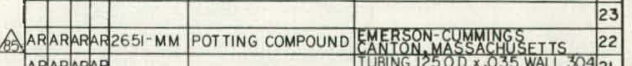

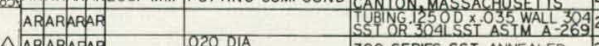

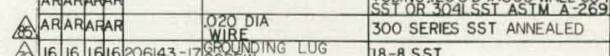

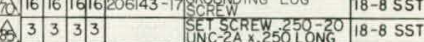

10

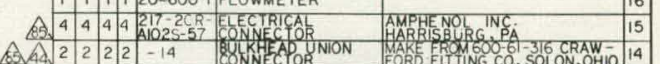

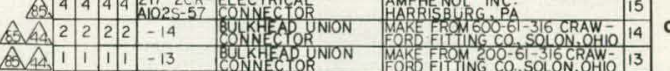

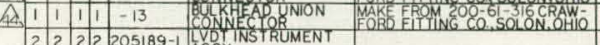

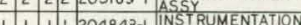

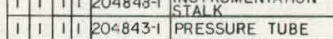

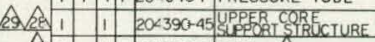

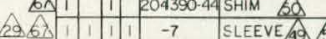

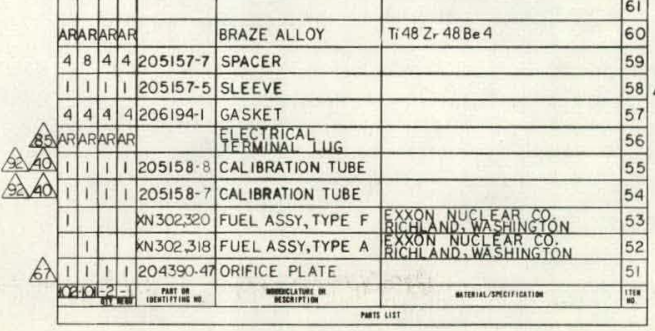

\begin{tabular}{l|lll}
1 & 1 & 1 & $204844-1$ \\
\hline
\end{tabular}

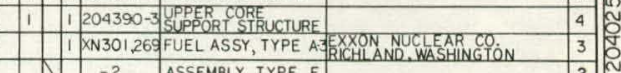

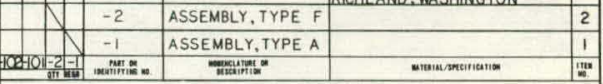

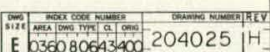

504025

6

5

Fig. A-15. 


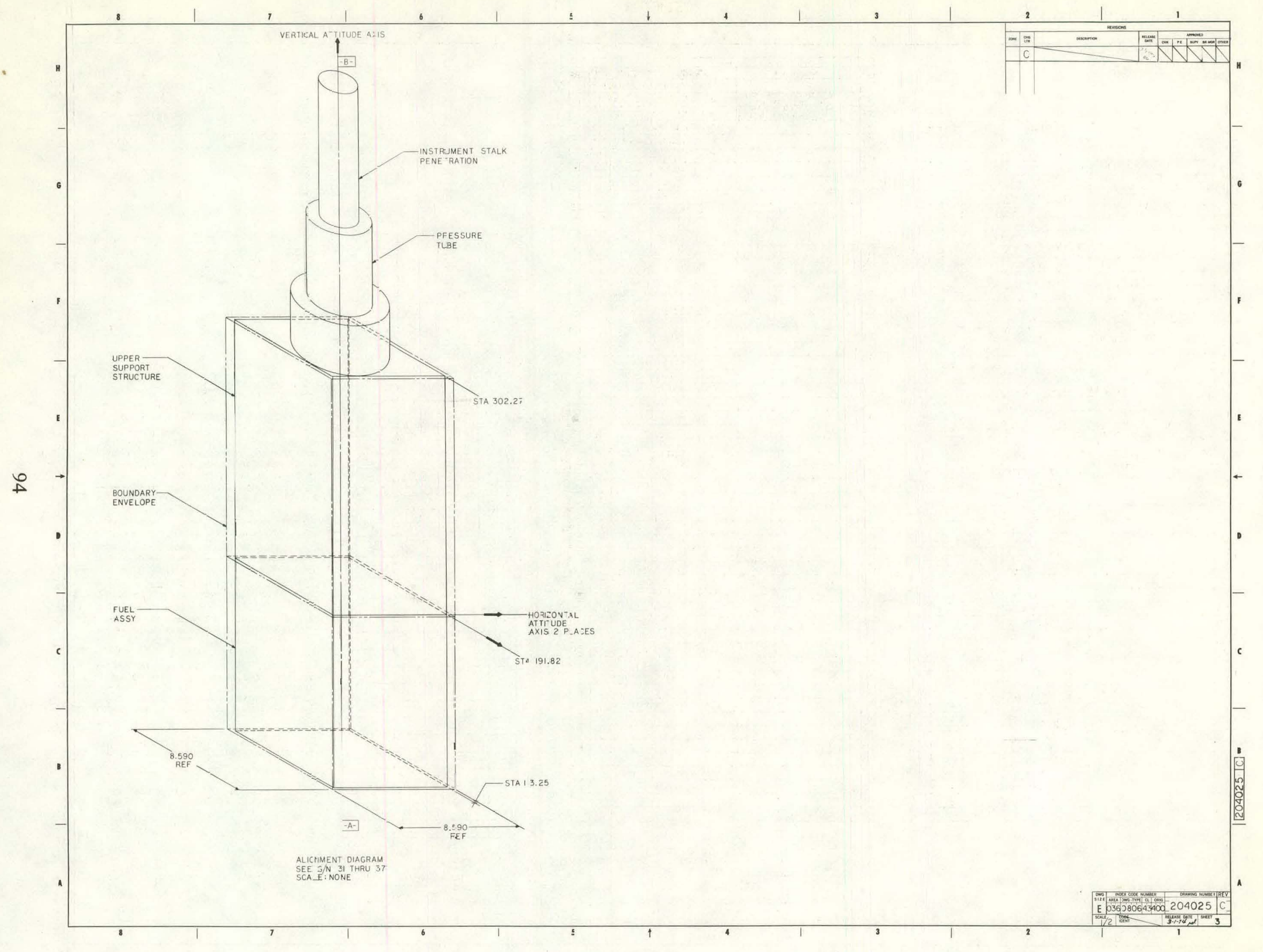

Fig. A-16. 


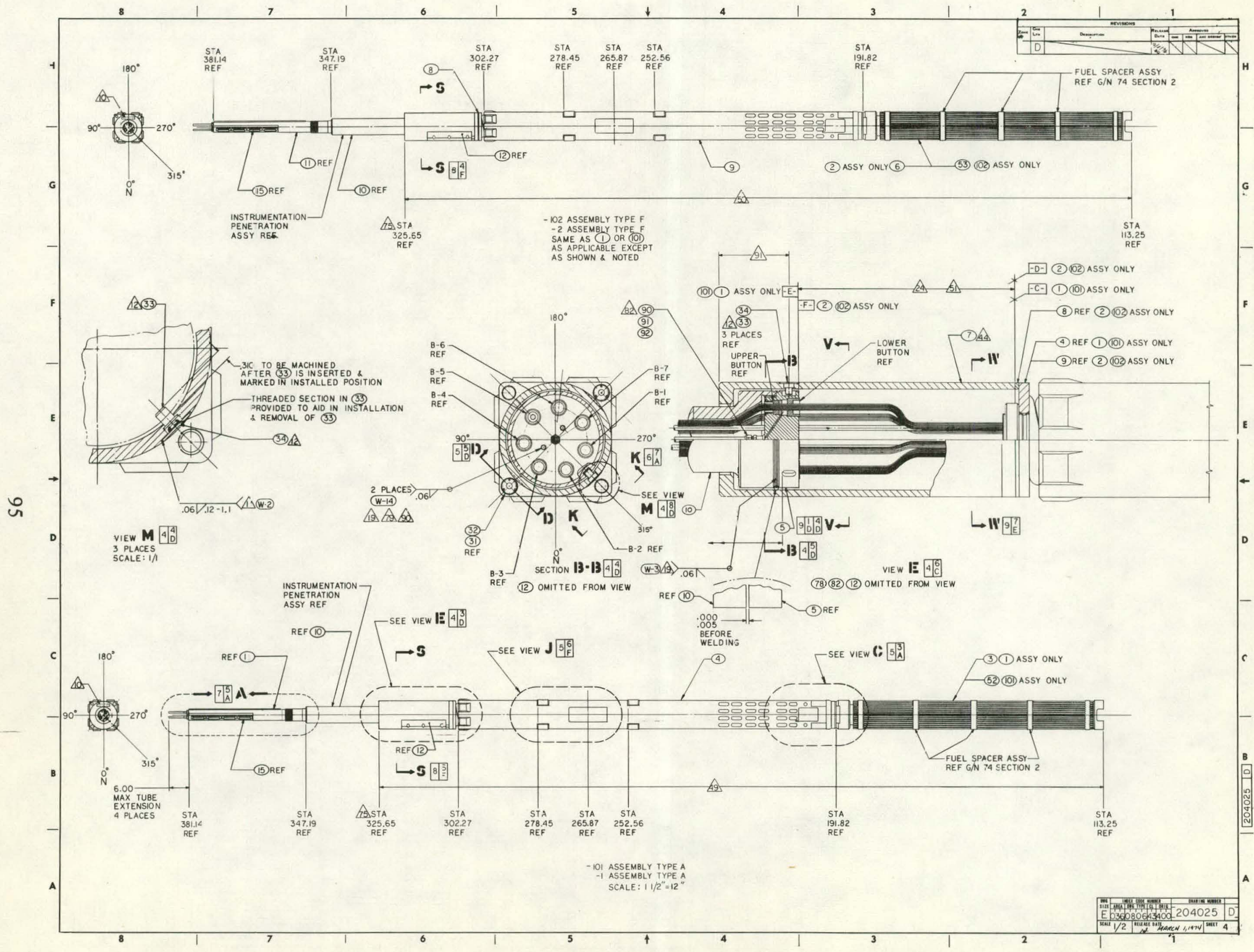

Fig. A-17. 


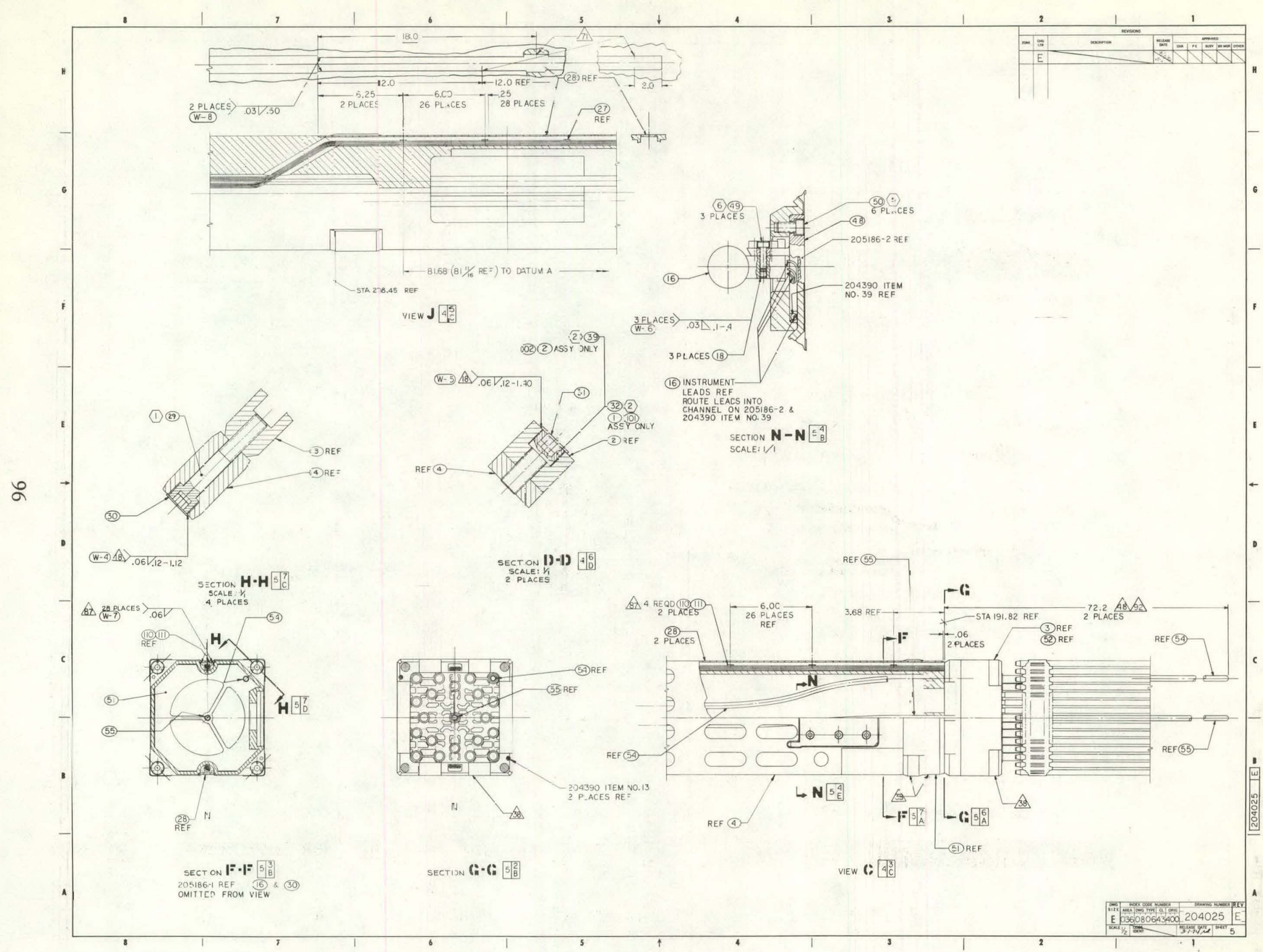

Fig. A-18. 


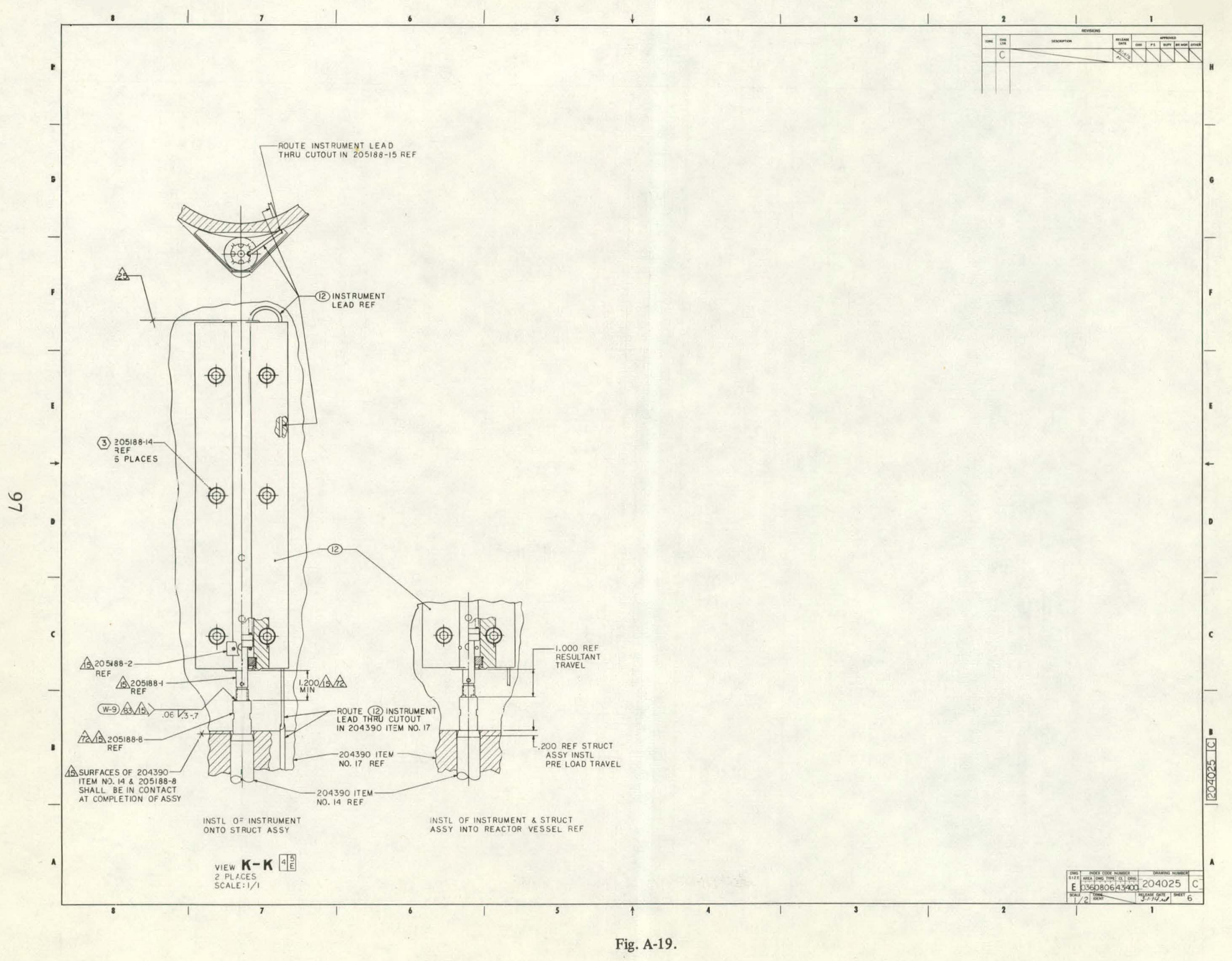




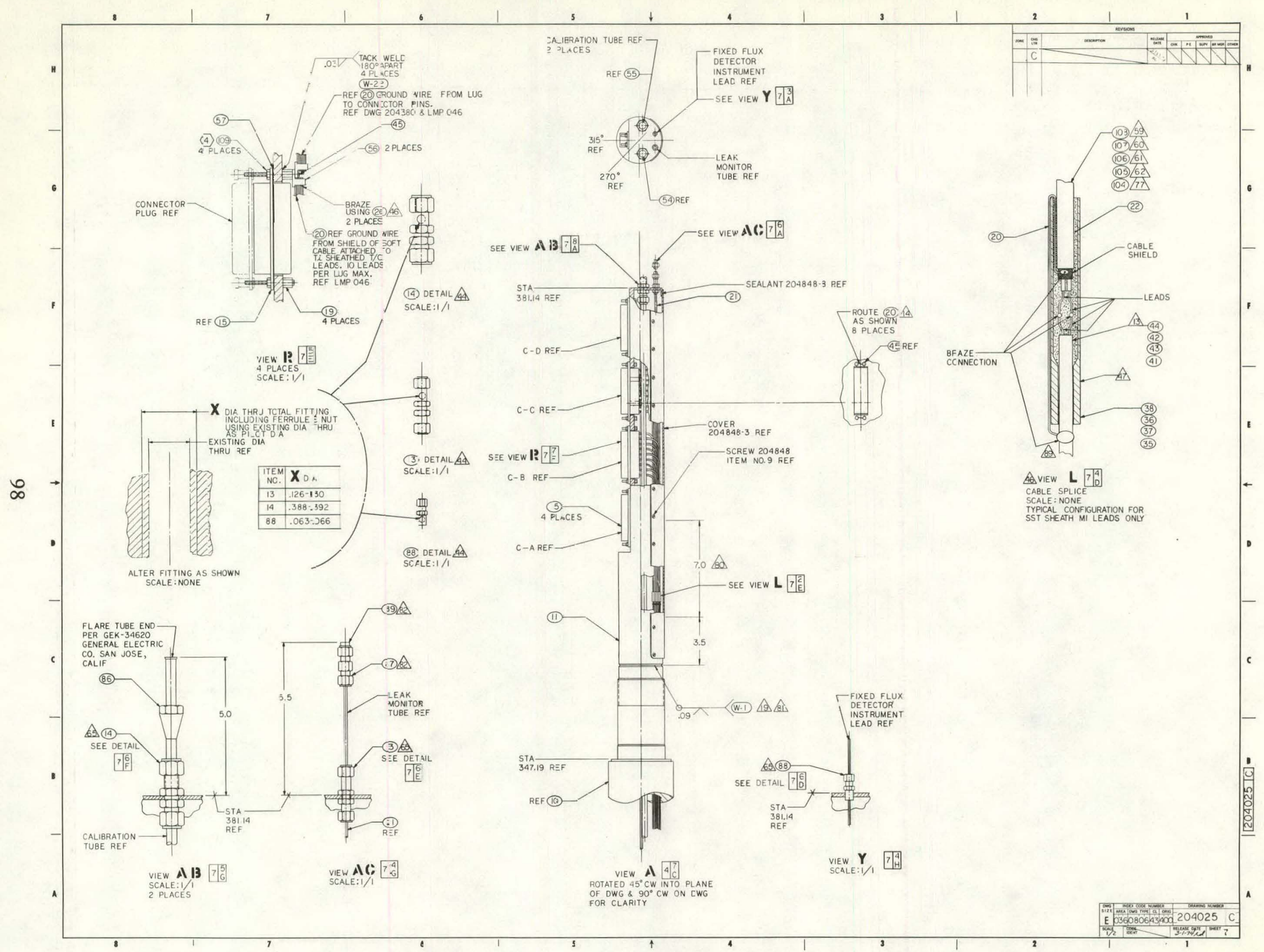

Fig. A-20. 


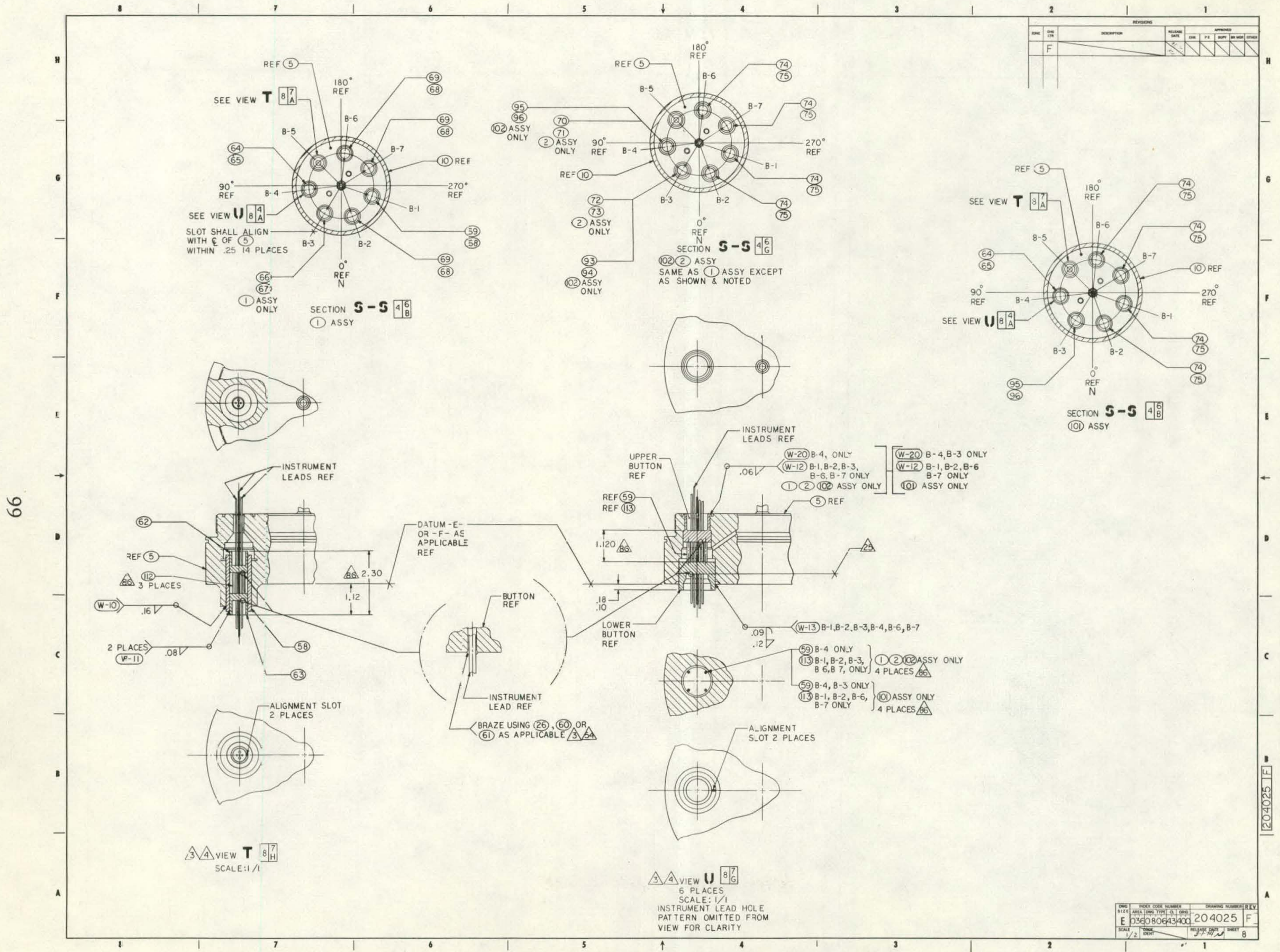

Fig. A-21 . 


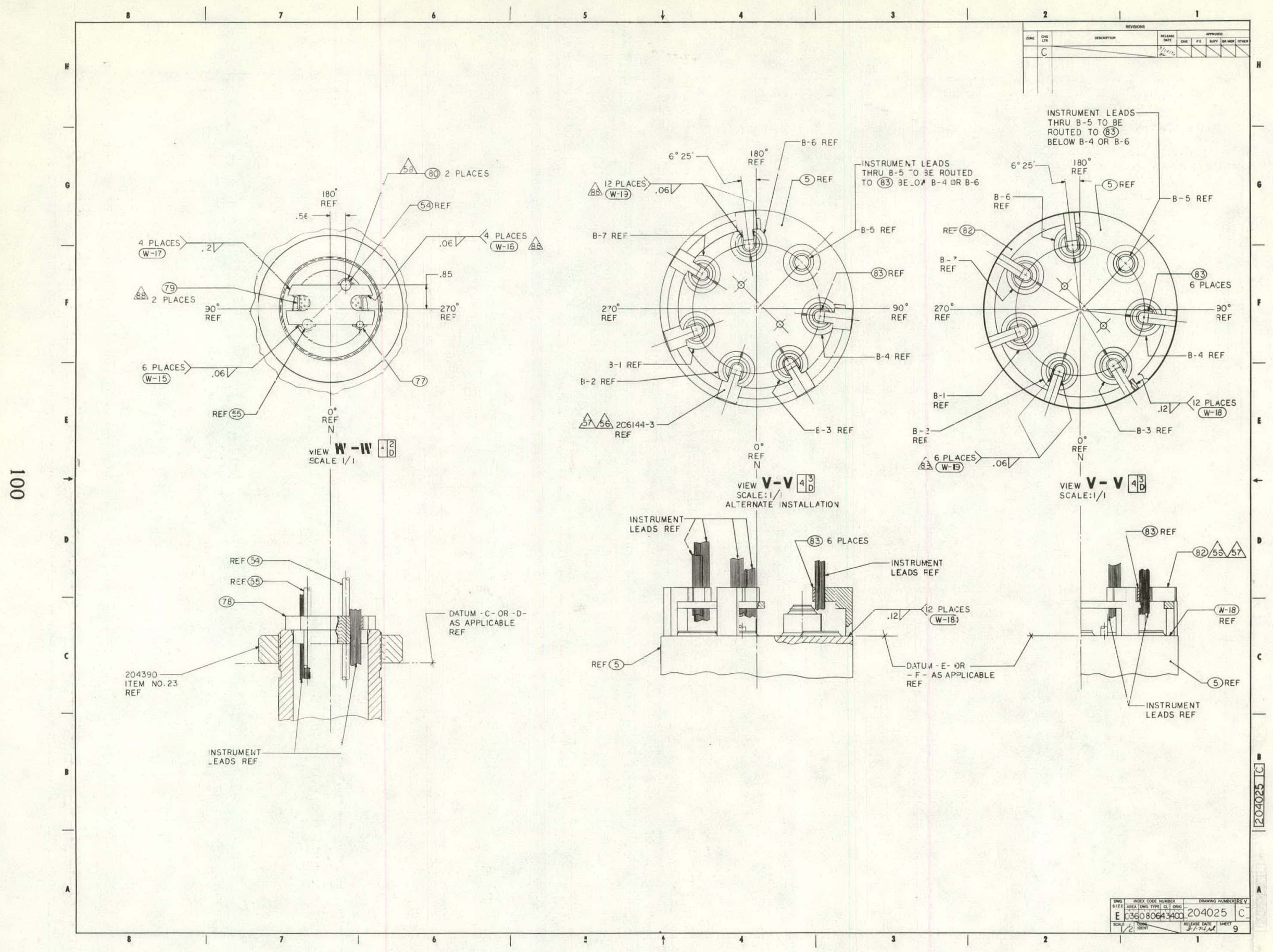

Fig. A-22. 
NOTES:
I REMOVE ALL BURAS \& SHARP EDGES.

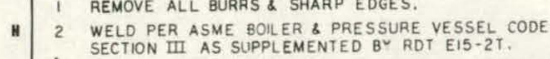

3. INSTRUMENT LEADS TO BE BRAZED INTO BUTTON
ASSYS PER ANC BRAZE PRDSEDURE BR $1.2 .460 \& 461$.

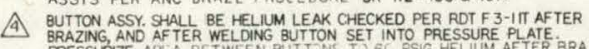

6 ALL WELDS PERFCRMED AT THIS ASSY TO BE

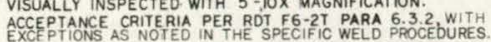

LOCK CUNS TO BE LOCKED BY DEFORMING CUP INTO
GROOVES ON CAP SCREW HEAD EXCEPT AS NOTED.

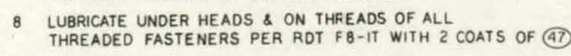

9 TORQUE FASTENERS PER ROT F8.IT TO VALLE SHOWN IN TORQUE TORQUE TO ZERO \& RETOROUE TO FINAL TOROUE
VALUE \& LOCK IN PLACE AS SHOWN OR NOTED. REF 3 .

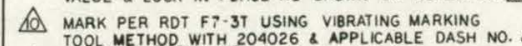

$\triangle 1$ ASSGENEE SERIAA NDROMEL-ALUMEL THERMOCOUPLE

A2 TO BE USED WITH PLATINUM-RHODIUM THERMOCOUPLE

43. TO BE SUPPLIED AS PART OF INSTRUMENT O

4. LOCKWIRE PER RDT ME-2T CLASS B.

15. THESE PARTS FURNISHED AS LOOSE PIECE ITEMS ON FABRICATION ONLY. SEPARATE ORDERING IS NOT REQ UNLESS PARIS AFE NOT INCLUDED IN THE PARENT

16. INSTALL FITTING PER VENDOR'S INSTRUCTIONS EXCEPT
TORQUE $1 / 4$ TO I/2 TURN BEYND FINGER TIGHT

17 SURFACE ROUGHNESS 125 UNLESS OTHERWISE NOTEO.

18. WELL TO BE PERFormed after IINAL INSTALlation

19. LIOUD PENETRANT INSPECT PER ROT F3-6T.

20 Doenotes torque requirements. See table

21 W-X DENOTES WELL IDENTIFICATDN NO.

22- WELD TO BE PERFORMED IN LOWER 7.43 INCHES

23 CAUTION: WELDS TO BE PERFORMED ALTERNATELY ON TEMPERATURE BETWEEN WELOS TD MINIMIZE

24. ANY INSTRUMENT WHIOH ORIGNATES BELOW SURFACE EM-

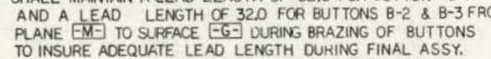

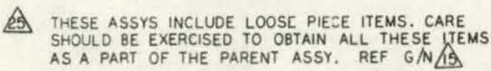

THREAD LENGTH SHALL BE 1.12 MIN. SCREW HEAD
TO HAVE.OOE2 DIA HOLE THRU TO ACCOMODATE LOCKWIRE

SIIE NOTED.
SCREW HEAD tO HAVE. O4O DIA HOLE THRU TO ACCOMODAT

28 STAKE OR PEFORM CHANNEL DOVE TALL EDGE ON 12.0

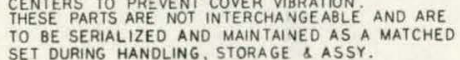

30 ASSEMBLY SEQUENCE FOR THE FUEL MODULE ASS SHAL BE IN ACOREDANCE WTH THE APPLIIABLE
SECTIONS OF THE LOFT FUEL HANDLING MANUAL.
32 DATUM L-B. IS DEFINED AS THE VERTICAL REFERENCE
CENTERIINE PASSING THROUGH THE CENTERS OF THE 8.449-8.4C6 SQUARE UPPER SUPPORT STRUCTURE
OOCATING FADS AT STA 278.46 EXCEPT AS NOTED

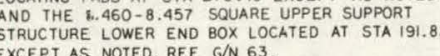

33 DURING ASSY. HANDLING \& STORAGE OF THE FUEL MOOULE ASSYS. (1) OR 2), PRECAUTIONS SHALL BE TAKEN CAUTION: THE FUEL ASSY (3) OR (6) AND/OR FUEL

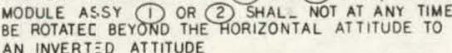
ASSEMBLY (3) OR (6) SHALL BE OARENTED TO EACH
BY MATCHING THE OWER END BOX FLANGE DOWEL PIIS OF 4 CHNG AND UPPER END BOX ALIGNMENT HOLES OF

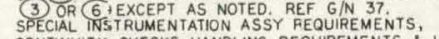

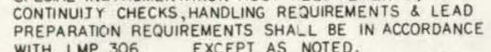

13A THE UPPEF SUPPORT STRUCTURE (4) AND FUEL ASSY (6)

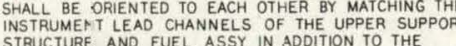

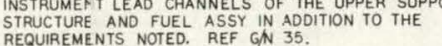

38 DATUM [-B] SHALL BE COANCIDENTAL WITH DATUM EA-
DURING AL GNMENT. REF GN 39 .

39 THE ASSEMBLED ALIGNED FUEL MODULE IN THE VERTICAL
POSITION BETWEEN STATIONS $13.25 \& 278.46$ SHALL FIT WITHN

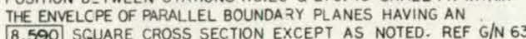

40 C-X DENO-ES CONNECTOR REFERENCE DESIGNATION.

4) DURING ASSY, HANDLLNG, STORAGE \& SHIPPING ACTVITTIES TO LOAOS GREATER THAN 36 .

42 DURING ASSY \&HANOLING ACTIVITIES WHICH ARE IN CLOSE PFOXIMIIY TO OTHER HARDWARE HE VERTICAL VELCCTY
OF AN UNS JPPORED FUEL MODULE ASSY (1) OR (2)
SHALL NO- EXCEED 40 INCHES/MINUTE.

43 OURING ASSY \& HANDLING ACTVIVTIES WHICH ARE IN CLOSE PROXIMITY TO OTHER HARDWARE THE HORIZONTAL VELOCE
OF AN UNSUPPORTED FUEL MOOULE ASSY OR OR (2)
SHALL NOT EXCEED 40 INCHES MININUTE. 44 RECORDS SHALL BE MAINTAINED FOR EACH FUEL
MODLE ASSY SO THA AL PARTS \& SUBASSEMBLES
CAN BE TF ACEALL TO FABRICATION \& SOURCE LOT.

WEIDING PROCEDURE OUALIFICATION \& PEAFO 5 WELDING PROCEDURE QUALLFICATION \& PERFORMANCE
OUALIFICATON OF THE WELERS SHAL BE IN
ACCORDANEE WITH RDT F6-2T WTH THE EXCEPTION

A HARD TO SOFT CABLE SPLICE JOINTS AND FINAL
CONOA CONNECCCR ASSEMBLY SHALL BE MADE IN ACCORDANCE
WITH LMP 224 \& LMP 046 .

AD INDIVIDUAL LEAD IDENTIFICATION TO BE TRANSEERRED
FROM TTE MII AABLE TOO THE PCTTING CUP AT THE

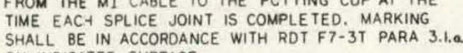

54. BUTTONS TO BE VISUALLY INSPECTED AFTER INSTALLATION

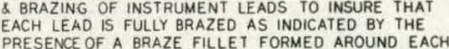

WEAD AT LOCATION SHOWN.
WHEN 2 OR MORE FASTENERS ARE REQD TO ASSEMBLE

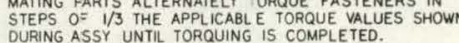

5D. INSTRUMENT LEAD ROUTING \& HOOKUP SHALL BE IN
ACCORDANCE WITH LMP 317 , FIG 1 .

S8. MARK PER RDT FT. 3T USING REMOVABLE TAG WITH
204026 AND APPLICABLE DASH NO.

59 REMOVED

UPPER SUPPORT STRUCTHER FUEL ASSY (3) OR (6) AND
SHALL BE.20 INCHES THE BOTTOM SURA ACE OF THE UPPER COOE SUPPORT
PLATE ASSY REF DWG 204098 TO THE TOP SURFACE

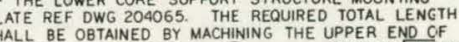
SURFACE [-C- OR
HE SPRING DEFLECTOR IN Q
-D- AS APPLICABLE, AS REQD TO OBTAIN DIM NOTED.

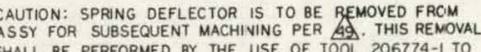
RETAIN THE SPRING AND SPRIAG DEFLECTOR DURING
DISASEMMIY. TO REAX SPPBNG AFER FLANGE INSTALLED PRELOAD OF $978-1037$ LBS WITH.872 THREAD
ENGAGEMENT ON 204386 ITEM NO. 31 , TOOL $206774-1$ MAY BE USED FOR COMPRESSING SPRING AND DEFLECTOR

34. PRIOR TO WELOING THE BUTTONS 68 THRU (73) INTO
(5 THE PRESSURE PLATE MUST BE POSITIONED AN CLAMPE WWTH RESPECT TO THE SUPPORT STRUCTURE (4)

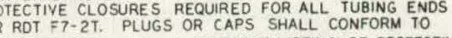
DEVICES NCORPORATED SHALL BE MAINTAINER, PRIOR
TO INSERTION OF THE FUEL MOOULE ASSY, D OR (2). DEVICES SHALL BE MADE TO INSURE THEIR OPOP

N INDICETED SUREACE.
53. CHANNEL COVER 204386 ITEM NO. 36 ; CLPP 204386 ITEM
NO.37; AND CLP 200386 ITEM NO. 41 MAY BE OMITTED
ON (1) ASSY ONLY.

56 B-X DENOTES INSTRUMENTATION BUTTON REFERENCE

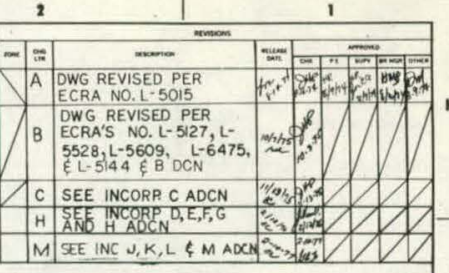
FOLLOWING STEPS:
THE AS BULT DIM F ROM THE TOP SURFACE OF REACTOR VESSEL INSTRUMENT
NOZZLES DESIGNATED J,GSN REF DWG 205142 TO THE BOT TOM OF THE PIVOT ARM SLOT IN
THE CORE BAREL REF STA 293.40 ON DWG
204059 IS 46.820. SUBTRACT .250 FROM 46.820.

3 SUBtract.125 From the RESULTANT DIM STEP 2 . IHIS WILL GIVE THE MAXIMUM
ALLOWABLE DIM NOTED ON THIS DWG.

4 IF THE AS BULT TOTAL DIM NOTED RESULTING
FROM THE ASSY OF (5), (10) 8 (17) EXCEEDS THF DIM DETERMINED IN STEP 3, MACHINE
SUPRACE -F- TO MAKE DIM NOTED AS RESULT SF ASY BE WIT WIN THE LIMIT
STEP 3 PLUS .000 MINUS 060 .

6. AETER MACHINING SPRING DEFLECTOR PER G/N AO FLANGE ONTO THE UPPER SUPPORT STRUCTURE ASSY,

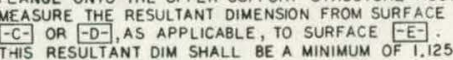
DIM APPLIES AFTER MACHINING PER 99 .

65 THOSE PORTIONS OF THE LOCATING PADS AT STATIONS EXTENDS BEYONO THE E.5.59O ENVELOPE ARE
EXCLUDED FROM THE REOUIREMENTS OF G/N 39.

64 OUPRNG HANDLLNG \& SHIPPING ACTIVITIES IN WHICH THE THE CONTROL ROD CLUSTER ASSY IG MUST BE
RESTRAINED IN THE FULLY INSERTED POSITION.

65 THE WITHDRAWL SINSERTION OF THE CONTROL ROD
CLUSTER ASSY 16 MUST BE CONTROLLE AT ALL TIMES ANO THE (16) ASSY MUST NOT BE ALLOWED TO

68 CAUTION: PRIOR TO INSTALLATION OF (16) ASSY INTO (1) OR (2) ASSY CHECK TO INSURE THAT CONTROL
POO SHAFT JN3O0,374 IS ORIENTED ON CONTROL ROD

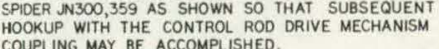

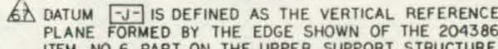

63) DURING ASSY \& HANDLING ACTIVITIES SUPPORT SHALL
BE PROVIDED FOR THE INSTRUMENTATION PENETRATION

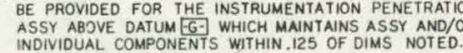
G/N CONTINUEd ON 228

SEE SHT 2 FOR LIST OF MATERIAL
6. THE DIM NOTED SHALL BE OBTAINED BY PERForMING

Fig. A-23.

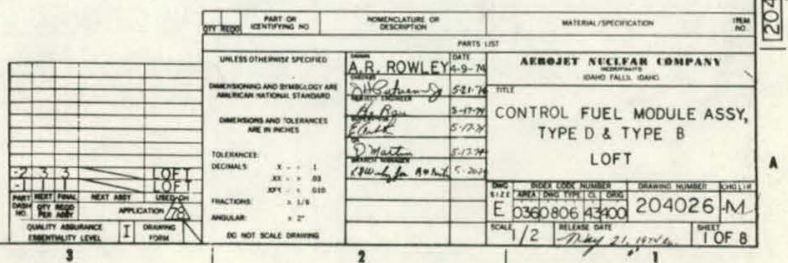




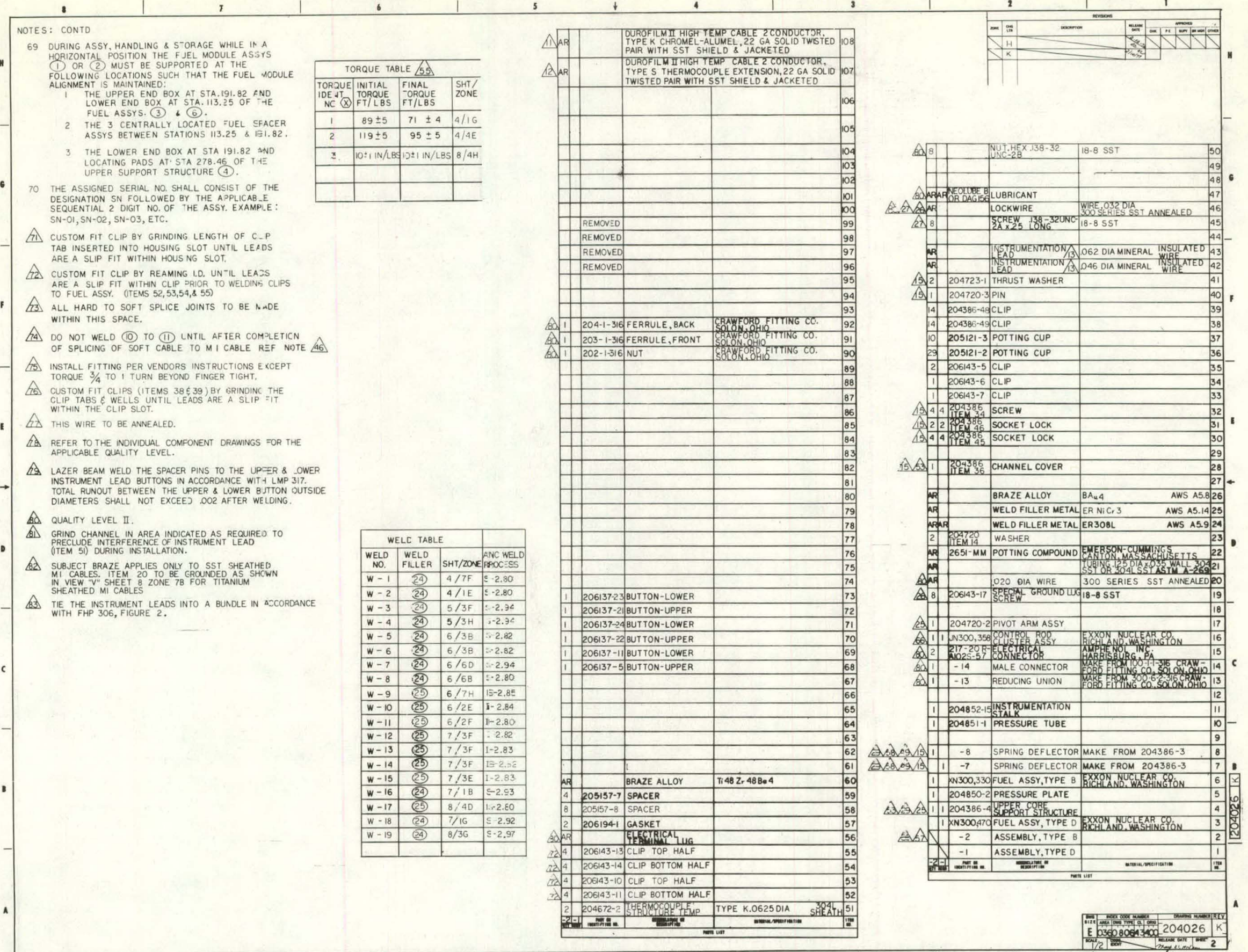

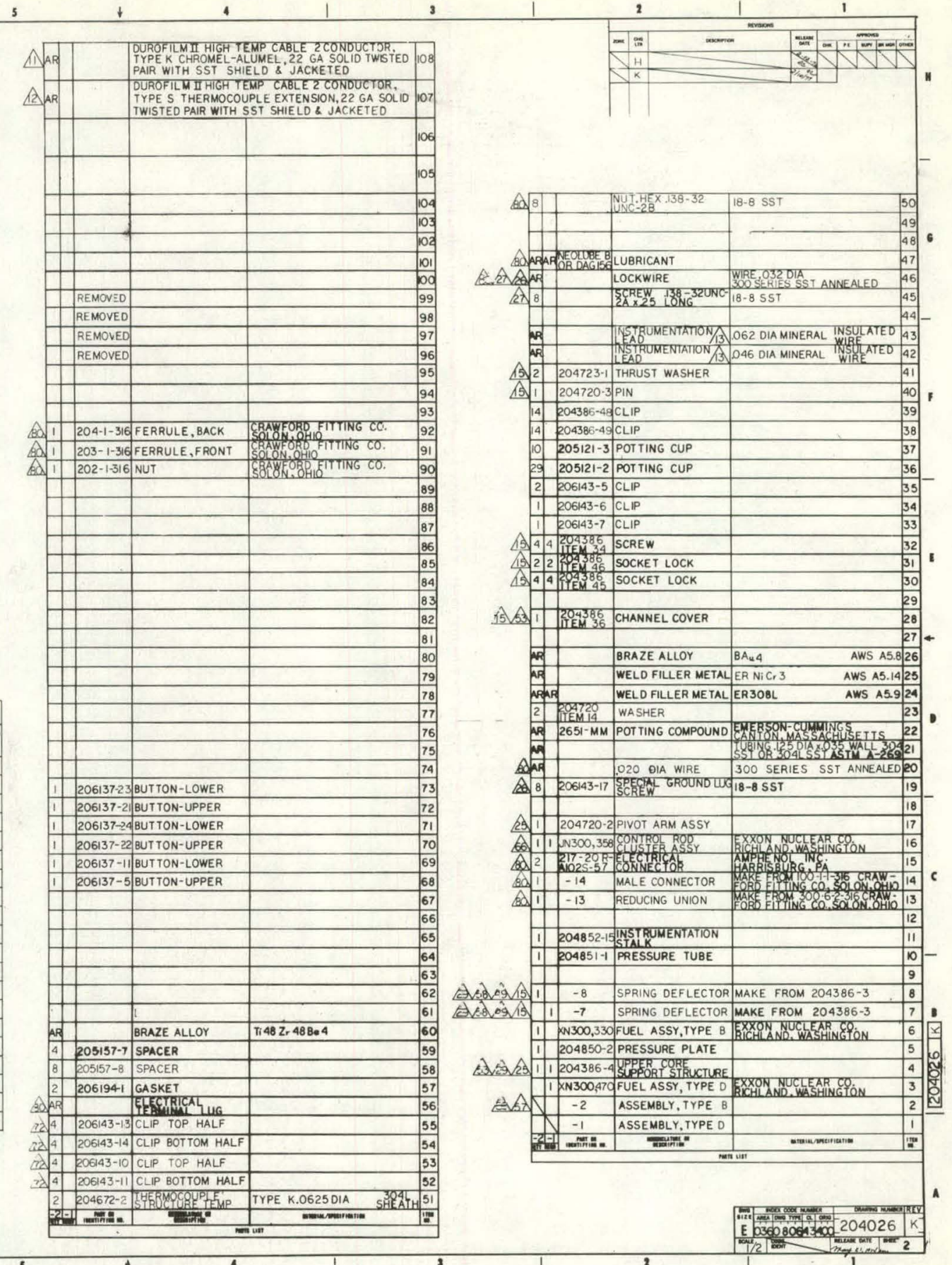

Fig. A-24. 


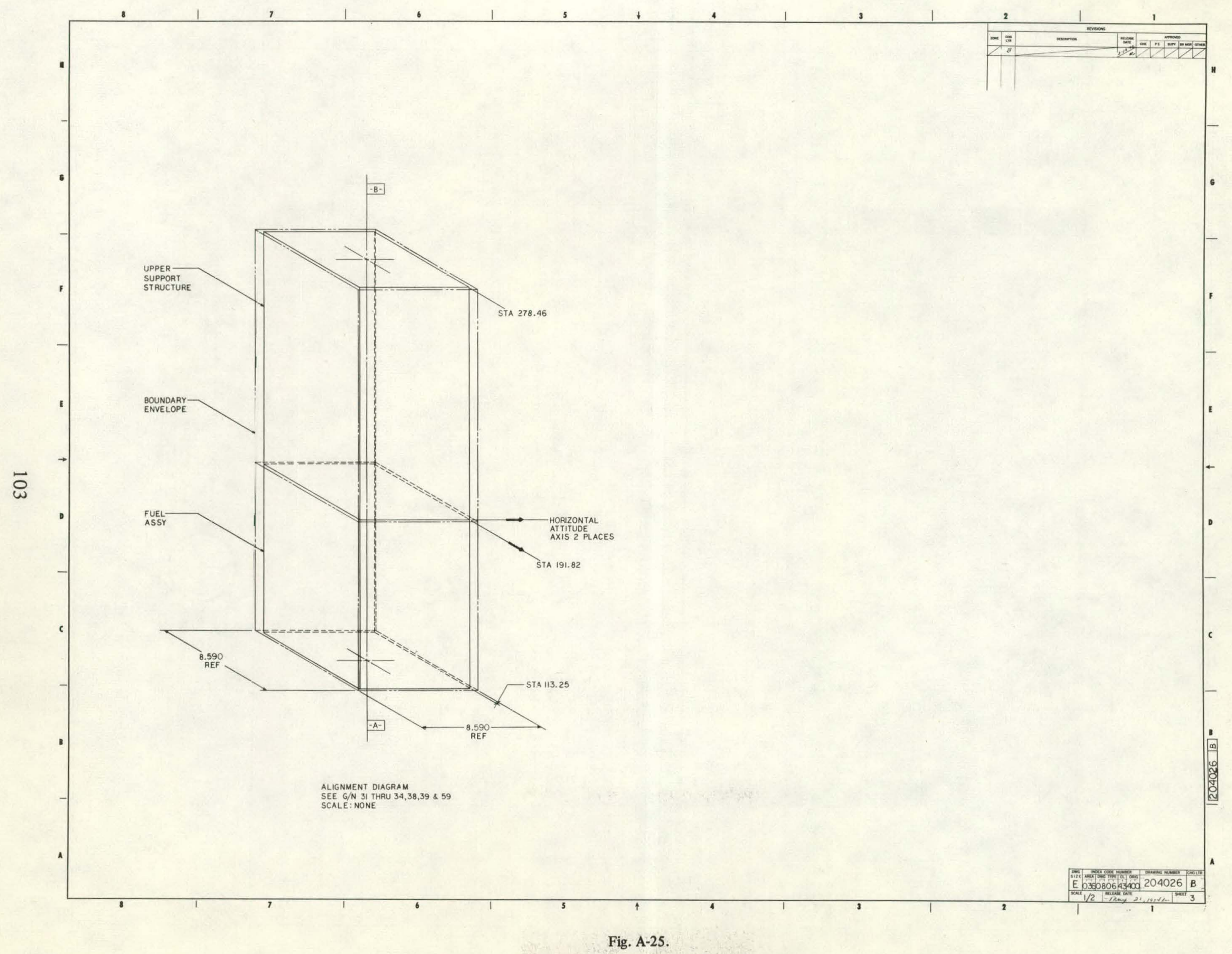




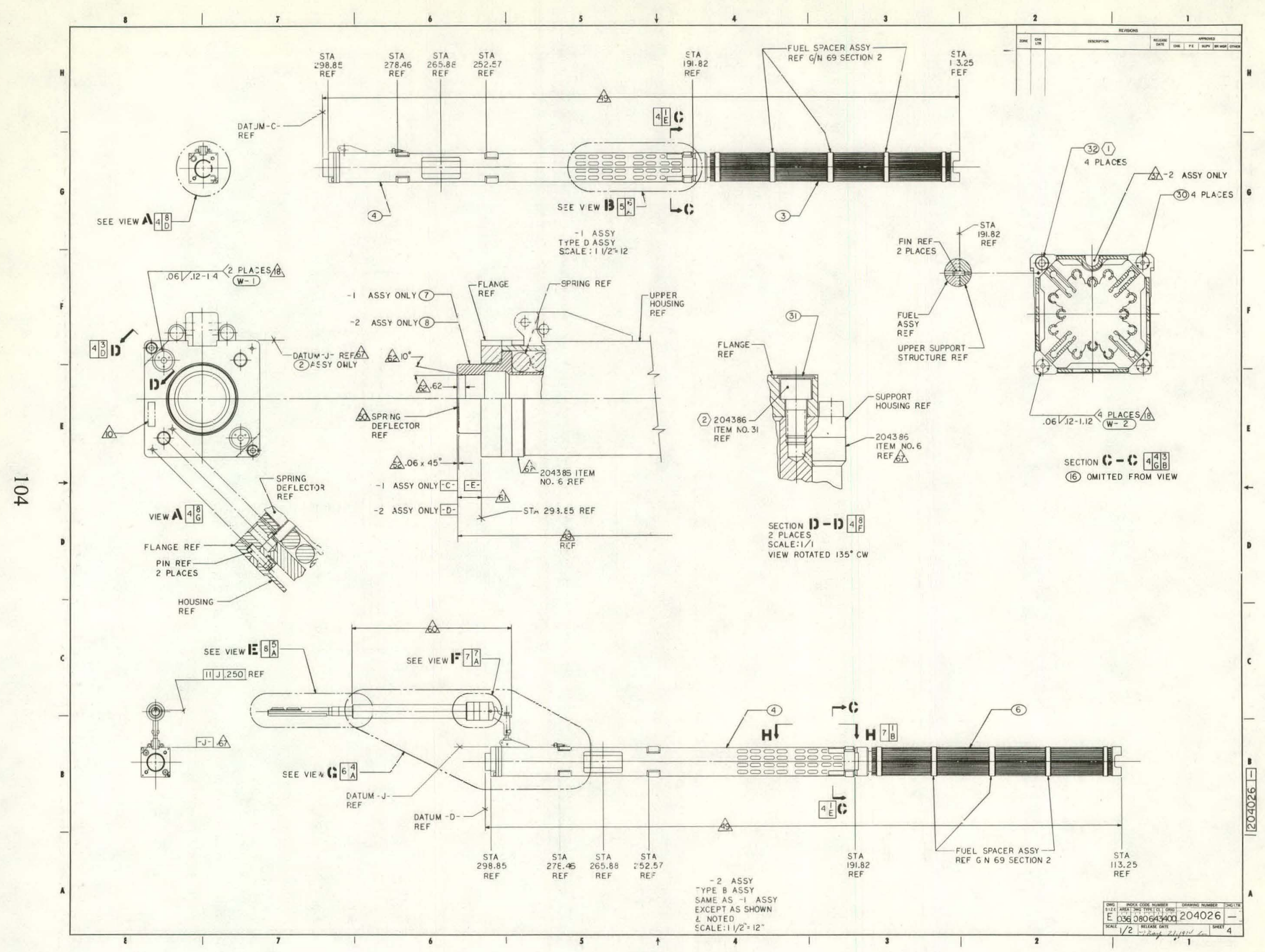

Fig. A-26. 


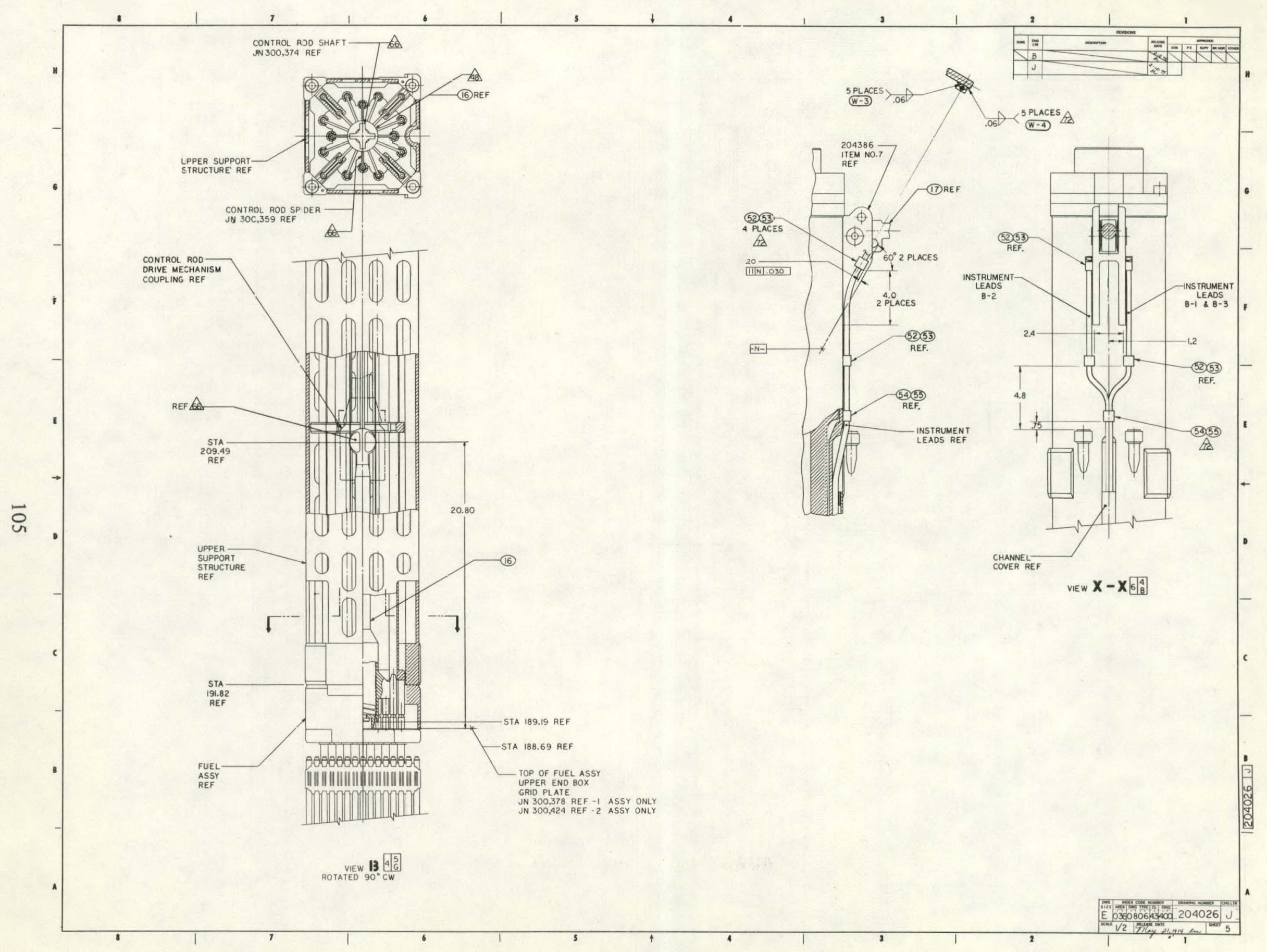

Fig. A-27. 


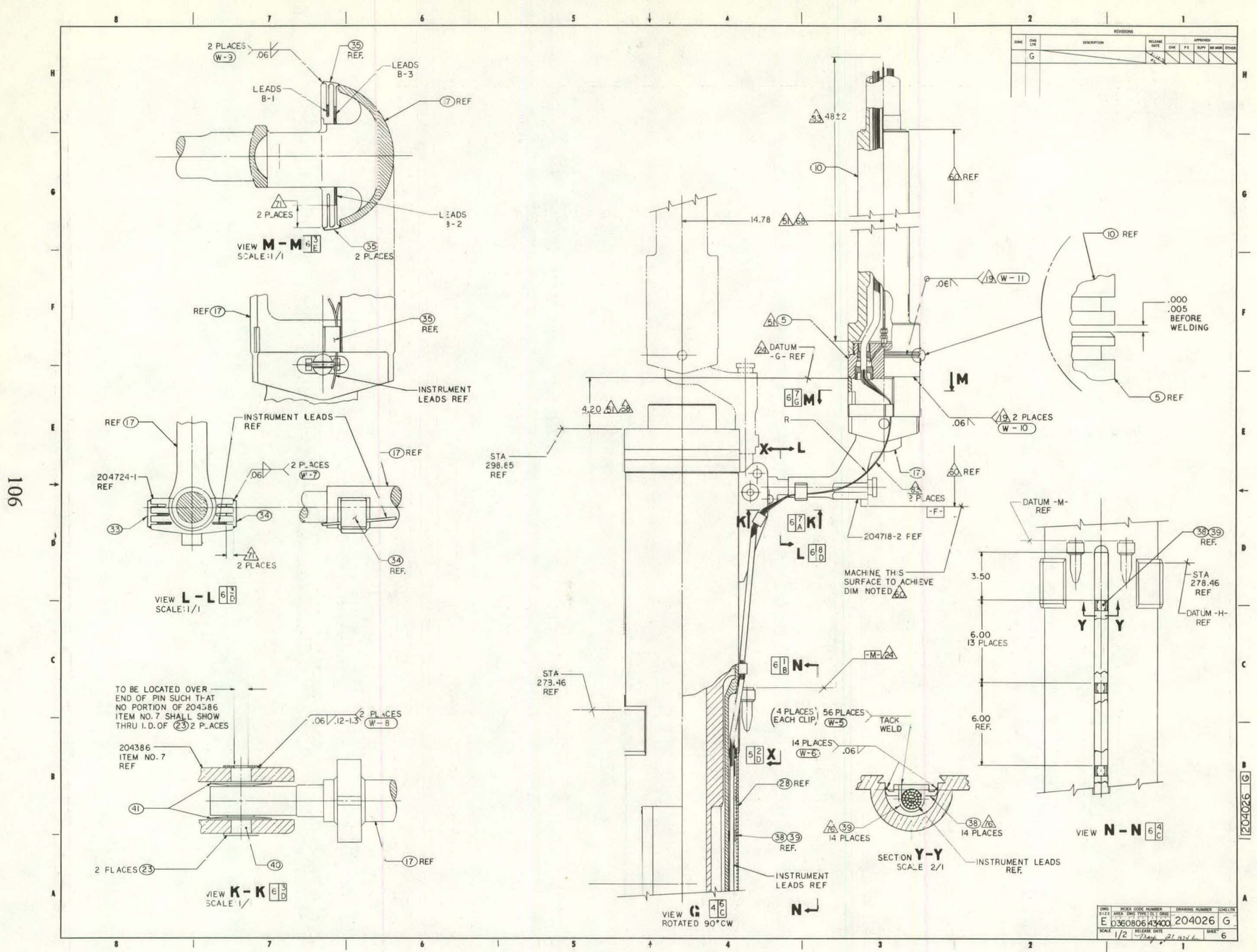

Fig. A-28. 


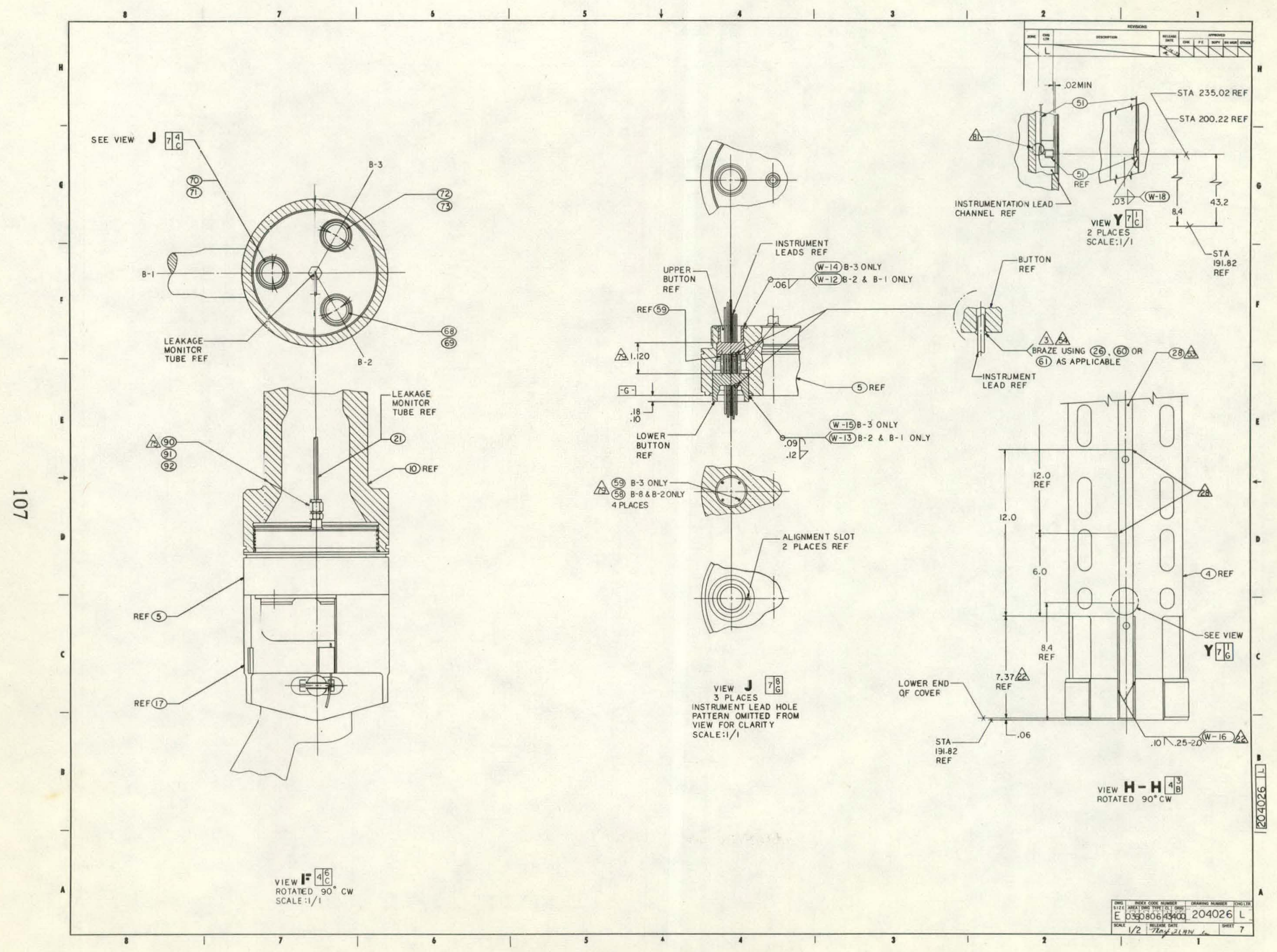

Fig. A-29. 


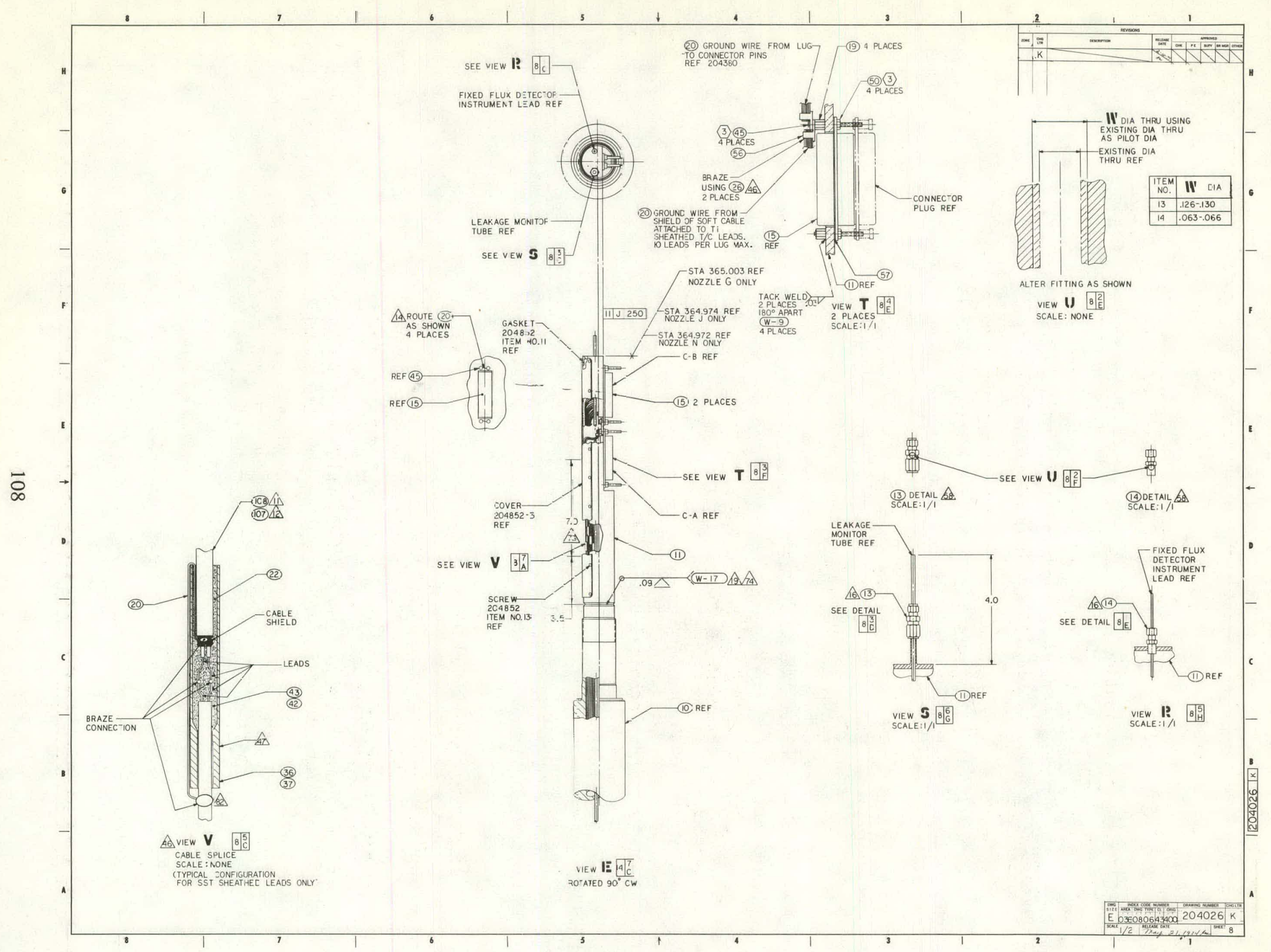

Fig. A-30. 
Internal Distribution

1 - Chicago Patent Group 9800 South Cass Avenue Argonne, Illinois 60439

2-4 - A. T. Morphew Classification and Technical Information Officer Idaho Operations Office - ERDA Idaho Falls, ID 83401

5 - R. J. Beers, ID

6 - P. E. Litteneker, ID.

7 - R. E. Tiller, ID

8 - R. E. Wood, ID

9 - H. P. Pearson, Supervisor Technical Information

10-19 - INEL Technical Library

20-39 - Authors

40-59 - Special Internal

\section{External Distribution}

60-61 - Saul Levine, Director Office of Nuclear Regulatory Research, NRC Washington, DC 20555

62-366 - Distribution under NRC-2, Water Reactor Safety Research Systems Engineering 